\title{
THE HISTORY, SYMBOLISM, SPIRITUALITY, AND TRANSFORMATION \\ OF THE JINGLE DRESS AND DANCE OF THE \\ NORTH-EASTERN WOODLAND INDIANS
}

\author{
by \\ IRMGARD STEGNER \\ A thesis submitted to the \\ Faculty of Graduate Studies and Research \\ in partial fulfillment of the requirement for the degree of
}

\section{MASTER OF ARTS}

Department of Sociology and Anthropology

\author{
Carleton University \\ Ottawa, Ontario
}

Fall 2008

copyright

2008, Irmgard Stegner 


$\begin{array}{ll}\begin{array}{l}\text { Library and } \\ \text { Archives Canada }\end{array} & \begin{array}{l}\text { Bibliothèque et } \\ \text { Archives Canada }\end{array} \\ \begin{array}{l}\text { Published Heritage } \\ \text { Branch }\end{array} & \begin{array}{l}\text { Direction du } \\ \text { Patrimoine de l'édition }\end{array} \\ \begin{array}{l}\text { 395 Wellington Street } \\ \text { Ottawa ON K1A 0N4 } \\ \text { Canada }\end{array} & \begin{array}{l}\text { 395, rue Wellington } \\ \text { Ottawa ON K1A 0N4 } \\ \text { Canada }\end{array}\end{array}$

Your file Votre référence ISBN: 978-0-494-47504-1 Our file Notre référence ISBN: 978-0-494-47504-1

NOTICE:

The author has granted a nonexclusive license allowing Library and Archives Canada to reproduce, publish, archive, preserve, conserve, communicate to the public by telecommunication or on the Internet, loan, distribute and sell theses worldwide, for commercial or noncommercial purposes, in microform, paper, electronic and/or any other formats.

The author retains copyright ownership and moral rights in this thesis. Neither the thesis nor substantial extracts from it may be printed or otherwise reproduced without the author's permission.
AVIS:

L'auteur a accordé une licence non exclusive permettant à la Bibliothèque et Archives Canada de reproduire, publier, archiver, sauvegarder, conserver, transmettre au public par télécommunication ou par l'Internet, prêter, distribuer et vendre des thèses partout dans le monde, à des fins commerciales ou autres, sur support microforme, papier, électronique et/ou autres formats.

L'auteur conserve la propriété du droit d'auteur et des droits moraux qui protège cette thèse. $\mathrm{Ni}$ la thèse ni des extraits substantiels de celle-ci ne doivent être imprimés ou autrement reproduits sans son autorisation.
In compliance with the Canadian Privacy Act some supporting forms may have been removed from this thesis.

While these forms may be included in the document page count, their removal does not represent any loss of content from the thesis.
Conformément à la loi canadienne sur la protection de la vie privée, quelques formulaires secondaires ont été enlevés de cette thèse.

Bien que ces formulaires aient inclus dans la pagination, il n'y aura aucun contenu manquant.

\section{Canada}


The undersigned recommend to the Faculty of Graduate Studies and Research acceptance of the thesis

The History, Symbolism, Spirituality, and Transformation of the Jingle Dress Dance of the Eastern Woodland Indians submitted by Irmgard Stegner in partial fulfillment of the requirement for the degree of Master of Arts

Thesis Supervisor

Thesis Co-Supervisor - Second Reader

Chair, Department of Sociology and Anthropology

Carleton University

Fall 2008 


\section{Dedication}

For Ron, my great friend and confidante, who encouraged me when the going got tough, and who was my cheerleader during this project! 
ABSTRACT

Among Aboriginal peoples of North-America, the wearing of colourful regalia, singing and dancing to the beat of the drum and other instruments, whether for spiritual or temporal ceremonies, has been a way of life for millennia. However, from the mid-1800s to the mid-1900s, native Indians were either discouraged or forbidden by law to wear ceremonial dress and to perform any of their ceremonies.

Due to the reclaiming and resurgence by Indians of their cultural traditions during the latter part of the $20^{\text {th }}$ century, many of their ceremonies have become popular entertainment among non-aboriginal people at regional powwows, on television and in films. Nevertheless, stereotypes, biases, misconceptions, and misunderstandings still exist among the general public, often perpetuated by the same media which promote Indian culture.

By focusing on a particular form of regalia and dance such as the Jingle Dress and Dance, through research, observation, interviews, close examination and analyses, it is possible to gain at least a nominal knowledge and understanding of Indian traditions. The Jingle Dress regalia is worn and the dance performed by women only. The considerable transformation they have undergone over the past decades may be an indicator of the ongoing changes and adaptations occurring in the lives of North American Indians.

In this thesis I shall explore the Jingle Dress and Dance of the North Eastern Woodland Indians in the context of other North American cultural traditions. A close examination of the historical, symbolic, healing and spiritual aspects of this ceremony should also reveal possible connections to Indian women's identity, its transformation and relevance over time, as well as its potential for the future. Since the Jingle Dress Dance has strong links to medicine and healing, I shall also examine the significance of this factor of the tradition. 


\section{ACKNOWLEDGMENTS}

I wish to express my thanks and gratitude to all those individuals who guided and assisted me throughout the duration of my thesis project.

My thanks go to Mr. Simon Brascoupé (Carleton University) who first suggested that I consider researching the Jingle Dress and Dance for my MA-thesis. Until then, I had not known about it.

I want to thank especially Dr. Derek Smith, Adjunct Professor of Anthropology at Carleton University, for his extensive guidance and invaluable advice over the past several years. My thanks also go to Dr. Colleen Dell, Professor of Sociology at Carleton University (now Adjunct Professor) for her counsel and numerous suggestions, her patience and the time she spent with me discussing my thesis progress. Both, Professors Smith and Dell are members of my thesis committee.

I also wish to thank the various assistants at the Library and Archives of Canada (Ottawa) in conducting electronic research, as well as perusing their photographic collection.

A special thank you to various staff members of the library and archival division of the Canadian Museum of Civilization (CMC, Gatineau/Québec) who, at times, went out of their way to assist me. I am also grateful for the help I received from Dr. Benoit Theriault (Reference Archivist, CMC's Archives Division), as well as Mr. Louis Campeau (CMC, Audio Visual Archivist). Lastly, I want to extend my deep appreciation to the three aboriginal persons who willingly shared with me their knowledge, experience and insight, and so generously gave of their time to be interviewed. They wish to remain anonymous. 
Dedication

Page

Abstract

ii

Acknowledgment iii

Table of Contents $\quad$ iv

List of Maps, Illustrations, Photographs v-vi

Chapter I - Introduction

1. Introduction of Research Question 1

2. Purpose of this Thesis 6

3. Methods of Research 13

4. The Matter of Terminology 16

Chapter II - North-Eastern Woodland Indians

1. Early History and Geography 19

2. Beliefs, Myths, and Rituals 32

Chapter III - The Jingle Dress and Dance

1. History of the Tradition 52

2. Jingles and Tinkels - What do they mean? 63

3. Producing the Dress and Dancing the Steps 79

4. Symbolism of Regalia, Dance and Song 87

5. Relationship to Family, Community, Powwow, and Gender Issues 101

Chapter IV - Transition and Transformation

1. Change and Continuity - Is Transformation Desirable? 113

$\begin{array}{ll}2 . & 134\end{array}$

3. Concluding Remarks and Suggestions for Further Research 148

4. Assessment of Thesis 155

$\begin{array}{lr}\text { References } & 159\end{array}$ 
MAPS

Fig. 1: Map: Distribution of Eastern Woodland Indians; Storck, Peter L., “Ontario Prehistory" (1981)

Fig. 2: Map: Paleo-Indian and Archaic Sites Handbook of North-American Indians, Sturtevant, W. (gen. ed.), Vol. 15, p. 17 (1978); Smithsonian Institution, Washington, D.C.

Fig. 3: Map: European Entry into North America; Dubin, L.S., "North American Indian Jewelry and Adornment - From Prehistory to the Present". New York: Harry N. Abrams, Inc. (1999)

Fig. 4: Map: The Iroquois Confederacy; Wright R., “Stolen Continents” (1993)

Fig. 5: Map: Tribal Locations in the Eastern Woodlands Area, Willey, G. R., “An Introduction to American Archaeology" (1993)

Fig. 6: Map: Key to Tribal Territories, Sturtevant, W. (gen. ed.), "Handbook of NorthAmerican Indians", Northeast, Vol. 15, Smithsonian Institute, Washington, D.C. (1978)

\section{ILLUSTRATIONS AND PHOTOGRAPHS}

Fig. 7: Illustration: The Mounds are deciphered, Ceram, C.W., "Der Erste Amerikaner”, Reinbek bei Hamburg: Rowohlt Verlag GmbH (1978)

Figs. 8 \& 9: Photograph: Ojibway Women from Lake of the Woods, Rat Portage/ Kenora, Ontario, ca. 1905; Lake of the Woods Museum, Kenora, Ontario

Fig. 10: $\quad$ Photograph: Jingles on Male Powwow Dress (1930s); Roberts, Chris; Powwow Country - People of the Circle (1998)

Fig. 11: $\quad$ Photograph: Missionary with Dakota Sioux Girls, ca. 1930; Whispering Wind, Vol. 24, No. 2 (Summer 1991

Fig. 12: Photograph: Chippewa Maidens on Itasca State Golf Course, July 1932; photograph from the Minnesota Historical Society, Saint Paul, MN 
Fig 13.: $\quad$ Photograph: The Son and Daughter of Mrs. Maggie Wilson, 1933; Ruth Landes in "Religion and the Midéwiwin", Madison: University of Wisconsin Press (1968)

Fig. 14: Photograph: Maggie White participates in the Windy Boy Family Giveaway"; Marra, Ben Powwow - Images Along the Red Road; New York: Harry N. Abrams Inc. (1996)

Fig. 15: Photograph: Copper Hair Ornaments; Quimby, G.I., "Indian Culture and European Trade Goods “ (1966)

Fig.16: Photograph: Brass Tinkling Cones attached to a leather bag, 1700s;

Quimby ."Indian Culture and European Trade Goods" (1966)

Fig. 17: Photograph: Pouch with metal cones, Eastern Woodlands (Chippewa), ca. 1780; Ewing D.C., "Pleasing the Spirit" (1982)

Fig. 18a) Photograph: Ojibwe Dance Sash with Copper Cones; Diamond et al; "Visions of Sound" (1994)

Fig. 18b) Photograph: Ojibwe Drum with Jingles, Diamond, et al, "Visions of Sound" (1994)

Fig. 19: Photograph: Male Dancer's Skirt with Metal-Cone Tinkles; Heth, Charlotte (ed.) in "Native American Dance: Ceremonies and Social Traditions"; Washington D.C.: Smithsonian Institution (1982)

Fig. 20: Photograph: Rolling Lids into Cones; Johnston, J. and M., "Jingle Dresses”, Whispering Wind, Vol. 24, No. 2 (Summer 1991)

Fig 21: Illustration: Slide Dancing; Johnston, J. and M., "Jingle Dresses”, Whispering Wind, Vol. 24, No. 2 (1991)

Fig. 22a)b): Illustration: Jingle Dance Songs; Music Notes, Songs 18 and 19; Berbaum, Sylvie, “Ojibwa Powwow World” (2000)

Fig. 23: $\quad$ Photograph: Jingle Dress Dancer; Marra, Ben, "Powwow - Images Along the Red Road"; New York: Harry N. Abrams Inc. - A Times Mirror Company (1996) 


\section{CHAPTER I}

\section{INTRODUCTION}

\section{Introduction of Research Question}

Ethnic dress, music, song and dance in many countries and regions around the world communicate who the wearers and performers are and how they demonstrate to others, and to themselves, their unique traditions, values, and beliefs. Festive celebrations, religious and secular, provide opportunities for individuals, communities and nations to reinforce the ties to their land and their history.

In some parts of the world, dress and adornments have undergone not only a revival, but a marked, at times dramatic transition. The reasons were manifold, such as ethnic conflicts, colonization followed by decolonization, after which new regions and nations emerged and, in the second half of the $20^{\text {th }}$ century, westernization and tourism. Whatever the outcome of these changes, people continue to dress and celebrate. People want to know who they were, who they are now, and who they might become in the future.

Most profoundly affected by colonization were the Aboriginal inhabitants of the American continent. European settlers not only caused their geographical displacement, but the introduction of agriculture, the horse and other domestic animals, new types of tools, the weaving of cloth, coloured beads, etc., all of which greatly effected the production of their regalia and ornamentation. As Aboriginals' physical attire became more elaborate, some of its symbolic meanings began to differ from their former traditional ones. New stories and myths were created by Chiefs, Elders and others which, in turn, introduced new regalia, musical instruments, songs and dances.

'Dressing up' is life for native Indians, a vital element of their lifestyles, a past and present tradition that "seems to take people out of the mundane and awaken them to 
life and reality in a higher sphere", while "myth has the function of conveying spiritual guidance and arousing a particular state in individuals" (Prattis 1997:155, 157). Aboriginal people, once steeped in the riches of their ancient myths, possessed this spiritual guidance, then almost lost it until they began to rediscover and regain their old myths. Over the past several decades, however, they have been on a path of constant renewal. With the above focus in mind, it is worth mentioning that, until the early- to mid-1900s, Aboriginals in North-America were either discouraged or forbidden from performing any rituals, holding powwows or other celebrations. Canada's federal Department of Indian Affairs passed a bill in 1914 to forbid "Indians to participate in any show, exhibition, stampede or pageant in aboriginal regalia" (Blundell 1993:333). Since the 1960s, however, numerous powwows have been held throughout Canada, events that are now viewed as displays of aboriginal culture (1993:338-339).

Focusing on merely one such forbidden ritual - the potlatch - one gains an understanding of the magnitude of a government law that tried to eradicate a vital element of a peoples' cultural practices, and why it could not succeed.

What is a potlatch? Among the Northwest Coast natives such as the Kwakiutl it "was the occasion at which a traditional name, rank or hereditary privilege was claimed through dances, speeches and the distribution of property to those invited" (Cole and Chaikin 1990:5). They show that displayed property would also include songs, dances, and masks, together with their rights and the "history of their transmission". Awarded with their new names and rank, these members were now privileged to use them. To complete the ceremony, gifts, as a form of payment, were distributed to the guests; "the claims had to be publicly witnessed to be valid". Reciprocity too was part of the ceremony and the order in which gifts were presented, as well as their amount, endorsed the guests' new status.

There were varied reasons for holding potlatches such as the naming of a child, a 
girl's first menses, recovering of bridal payments, death, and the hoisting of a memorial pole, as well as other significant events in a person's life cycle. Potlatch means 'to give' or 'give away'. It was always followed by feasting and dancing, sports, gossiping and later also by drinking. Helen Codere who studied potlatch history, stated that potlatch gained greater importance in size and frequency among West Coast Indians (i.e. Kwakiutl) after the mid-1800s when trading posts began to operate in the area, such as the Hudson's Bay Company. Contact with Europeans increased Indians' wealth, and the availability of European tools helped to produce totem poles and ceremonial regalia heightened potlatching feasts during the $19^{\text {th }}$ century $(1950: 6,8-9)$. Yet, due to religious conversions (and other factors), a marked decline of the potlatch occurred by the end of the $19^{\text {th }}$ century; only among the Gitksan, Tsimshian, and Southern Kwakiutl did it actually intensify. Overall, however, it remained as a social system, and gift-giving continued as an important tool for recognizing "the rank and prestige that were fundamental to North West Coast Indians" (1950:10). But many, though not all missionaries and the Canadian federal government thought otherwise.

The potlatch tradition was considered immoral and a hindrance to Aboriginals' assimilation into European-Canadian society. Since religious life and ceremonies were interconnected with Aboriginals' social, economic and political existence, such values had to be destroyed. According to one Anglican missionary, shamans were sinister, dancing was "frivolous, and potlatches wasteful" (Pettipas 1994:ix, xi, 89). To suppress the potlatch, the Indian Act was amended in 1884-1885, declaring the potlatch ceremonies (as well as medicine or healing ceremonies) a misdemeanor and an offence. It became known as the Potlatch Law and became a precedent-setting legislation to transform Indian cultures (Cole and Chaikin 1990:14; Pettipas 1994:93).

Although the Canadian government received petitions even from several Indian Chiefs, demanding the enactment of an anti-potlatch law as early as 1883 (Cole and 
Chaikin 1990:16), there were also petitions to abolish the legislation, though these were never seriously considered by the Department of Indian Affairs (Pettipas 1994:94). It is worth mentioning that the Potlatch Law received its first "historically important" test case in 1889 when a Kwakiutl Chief was convicted, sentenced and imprisoned. According to Chief Justice Sir Mathew Begbie, however, the potlatch was legal as long as no "liquor, rioting, and debauchery" were involved, and as long as the Statute was unclear in defining "what specific acts constituted a potlatch". After much debate, the Potlatch Law was rewritten and the Indian Act amended and passed in July 1895. It now included a "definition of illegal activities" related to the potlatch ceremonies (1994:94-95).

After outlawing the potlatch, the Canadian government even seized its artifacts, so they could be "studied and protected" (Wheeler, Shandel 1975). More precisely, ceremonial gear such as coppers, masks, rattles, whistles, were gathered, sent to Ottawa, and the collection divided between three museums and one private collector (Alfred 1980). The actual enforcement of the Potlatch Law soon became a major challenge. Cole and Chaikin explain that the opposition of several Indian tribes, the government department's inability to enforce its own law, the lack of police support, and the disagreements between provincial and federal governments, all combined to make enforcement impossible (1990:34).

After a large potlatch was held at Village Island in 1921, during which many people were charged and some arrested, the potlatch went underground for a number of years to avoid further arrests. It became clear that the law was not enforceable and the Indian Act was revised again in 1951 by deleting Section 149 (Alfred 1980). When the Kitwanga Indians declared in 1890 that the law "was as weak as a baby" - the Indians had triumphed! (Cole and Chaikin 1990:39). Had the enforcement of the Potlatch Law been successful, it could be inferred with certainty that further such laws would have followed. They could have forbidden most if not all Indian ceremonies and rituals across Canada in 
order to speed up assimilation, to 'civilize' the total Indian population, resulting in a cultural genocide from which they would have never recovered.

Long before the revision of the Indian Act, however, a revival of public ceremonies was already taking place throughout the 1940 , public dance troops formed, which in turn contributed towards a resurgence of the potlatch. Eventually, after lengthy negotiations, the seized potlatch paraphernalia was returned to the Aboriginals, while some artifacts were housed in museums across Canada (Cole and Chaikin 1990:173). Several factors played a part in the potlatch resurgence. A profound one seemed to be that the "act of potlatching in and of itself has became a primary symbol of Indian identity", combined with a consciousness of the peoples" heritage, rights, and land, "a product of renewed pride and identity" (1990:173). Today, not only potlatch but most ceremonies and cultural gatherings have again become meaningful events in the lives of native Indians.

In my thesis I intend to provide as comprehensive an overview as possible, adding various components which are or may be linked to the Jingle Dress Dance tradition. The project is about its origin, links to the powwow, and the role gender may have played over generations. How relevant has this tradition been to Aboriginal women and their communities? Will it remain part of their identity in the years ahead? Considering the trends and ups and downs in popularity the Jingle Dress has undergone in the past decades, a number of questions have to be asked. For instance, will these trends cause the Jingle Dance Dress to lose its unique symbols? Will its healing power diminish, and will it be worth preserving at all? Although the tradition exists in various parts of NorthAmerica (i.e. the prairies, western Canada and the USA), which we must examine, I will focus on the people of the Eastern Woodland regions. Their primary bands are: Ojibway (Chippewa), Iroquois, Fox, Ottawa, Naskapi, Montagnais, Micmac, Penobscot, Cherokee, Creek, Menominee, and Winnebago. I shall be addressing their history, geography and 
culture in more depth in Chapter II.

Two important components, which are adding to the length of the thesis, are those of the geographical movements of some Eastern Woodland tribes, and that of archaeological findings. By examining both, I tried to establish a geographic context. The archaeological evidence in particular shows us that there is an unbroken persistence and continuity of spiritual ceremonial practices over the millennia. It also becomes clear that the Northeastern Woodland Indians are not the only ones practicing the Jingle Dress Dance tradition.

\section{Purpose of this Thesis}

The resurgence and reclaiming of cultural traditions by native Indians in North America over the past decades is well-known and well-publicized in television- and filmproductions (mainly as portrayed by Hollywood), magazines such as National Geographics, Canadian Geographics, and books. Most popular among many non-native people and tourists from around the world are such events as powwows and sweat-lodges. Despite the current popularity of native culture, biases, misconceptions and stereotypes still exist among the general public, perpetuated only too often by the same media which promote their culture. However, through research, close observation and analyses of native traditions in general, and through the focus on a particular form in which culture is actively expressed by the women and men, will it be possible to gain at least nominal knowledge and understanding of the past and contemporary native Indian way of live. The tradition of the Jingle Dress and Dance is hereby explored.

As already mentioned, stereotypes and preconceptions still prevail among the general Canadian public about native Indian lifestyles, from both historical as well as contemporary perspectives. People ask, "why do Indians still dress in feathers and fluff, dance in circles, stamp their feet and shout to the beat of a drum'? Haven't they buried 
their hatchets a long time ago? Yet, many non-native people enjoy Indian ceremonies, but usually lack the knowledge of their symbolic meanings or mythical linkage. School- and library books approach the subject of 'Canada's First People' in very general and somewhat superficial terms. Martin and Boyer opine that it is therefore necessary "to go beyond the colourful spectacle of the powwow ... beyond the exterior of the feathers and regalia to confront the stereotypes of Aboriginal peoples" that have been developed in the $19^{\text {th }}$ century by artists, such as painters and photographers, and the archetypal stereotype of the 'Hollywood Indian' in the $20^{\text {th }}$ century (2000:56).

How was the stereotypical Indian created? How could it have been created when one considers the leading roles they played in determining North American history? Doxtator's explanation points to the "power of images" which "linger in the minds of people long after reason has intellectually discarded them as spurious and untrue". The images created by movie makers, museums, academics, artists, etc., were "created for the purposes of the creators" to maintain the status quo, to produce "a type of fantasy diversion to better survive twentieth century industrial society". Distorted images hurt Indians and non-Indians alike. Perceiving "Indianness" as perfection, seeing Indians as saintly sages can be destructive. If Canadian society wants to treat Indians as equals, it has to stop defining other people, to stop telling them who they are and where they should "fit in" (1992:66, 68).

After the battle of Wounded Knee and the closing of the frontier in 1890, Indians disappeared from the "page of history". Academic textbooks, the media, and school books gave especially eastern Indians almost no attention. Even those authors sympathetic to the Indians' plight give them "bit parts" only in their roles as factors of North American history. Yet, exploration and colonization of North America would never have been possible without the assistance of the natives (Axtell 1981:XV, XVI). Once they were no longer needed by colonists and settlers and relegated to small pockets of 
land, called Reservations, they then became increasingly the victims of western stereotyping.

Contradictory images emerged. Indians were now savages, at best 'noble savages', the "only good Indian is a dead Indian" mentality gave way to a latter-day Hollywood "good Indian peace-maker", contrasted against the "bad Indian fighting whites" (Burke Leacock and Oestreich Lurie 1971:3). It is essential to point out that the label 'savage' and 'sauvage', used by both French- and English-speaking people for North American Indians "and their imagery", once connoted to woodland, a state of nature, became a derogatory meaning for humans on the lowest rungs of society. Nowadays, North American Indians refer to themselves as members of a tribe or nation, as Native, Indigenous or Aboriginal people. Consequently, the terms savage, noble savage, or noble Indian became the stereotypical usage by non-Aboriginals (Krech III 1999:16-17). Explorers, missionaries, and artists such as Kane and Catlin, further contributed to western stereotyping of North American natives, despite the latter's pro-Indian and fairly objective writings.

The image of the noble Indian also ruled the world of $19^{\text {th }}$ century literature, from Rousseau to Wordsworth and Taylor Coleridge, from Cooper to Thompson Seton and, even an Indian, Charles Eastman, a Dakota or Sioux (Krech III 1999:18-19), not to forget the prolific German writer Karl May. "Noble Indians have saturated public culture". From fiction, non-fiction and children's literature, the leap to the images in numerous Hollywood movies seemed just a short one. However, by the late $20^{\text {th }}$ century, the previous Wild West 'good Indian is a dead Indian' metaphor evolved into the 'Pocahontas' and 'Dances with Wolves' genre in which Indians almost reached sainthood (1999:21-22). Leonard George writes of Hollywood not only as a powerful and controlling media, but as an oppressor of native Indians, conjuring in people's minds first the romantic image of "feathers, beads, and noble warriors" with supernatural skills. 
Concurrently, Indians were seen as ignorant, animal-like, bloodthirsty beings who terrorized the plains" (in Jensen and Brooks 1991:167). In American elementary schools, high schools, as well as in colleges, native history is overlooked in preference of European settlers' and voyagers' New World history. At best, a schoolbook may have contained instructions on "wigwam building and firemaking". Nevertheless, a few enlightened scholars began in the 1970s to present a more balanced understanding and rounded perspective of North American history (Burke Leacock and Oestreich Lurie 1971:3-4). A Canadian high school textbook of the late 1970s had already devoted a 63page chapter on Canada's First People (pre- and post contact) before addressing the 'Settlement' history, and the issues of stereotyping and prejudices were dealt with on its first pages. Several pages instructed students about the impact of the Europeans on the native population, yet no mention was made of the oppression and cultural destruction, or of the residential school system suffered by the native populations, while the Indian Act was dealt with in merely $1 \frac{1}{2}$ pages. Although the Canadian schoolbook points out briefly shamanistic rituals and such games as lacrosse, there was a complete omission of the importance and uniqueness of Indian ceremonial life. Page and Da Rosa opine that schools' curriculum should also represent an acceptance of Indian culture, Indian values and attitudes, and the works of Indian artists, thereby going beyond the usual posters and slogans (1982:160).

Trigger goes on to explain that only a close and thorough anthropological understanding of aboriginal culture will be able to strike a balance "between the distinctive qualities of native culture and the equally important characteristics shared by all human beings". There has to be an awareness of native history beyond their relationship with non-natives, and increasing interest in native peoples in order to eliminate the confusing, contradictory, and incomplete views about them which have persisted for centuries. School textbooks Trigger regards as more crucial even than 
popular literature in influencing the non-native population. Although text- and schoolbooks have eliminated some of the stereotypes in recent years, they still reflect the historical omissions, in particular the evaluation of aboriginal culture in prehistoric times (1986: 46-47).

Bataille remarks that, despite the increasing number of native writers such as Charles Eastman, Gertrude Bonnin, and Simon Pokagon who wrote about their lives and cultures, it was not until some 70 years later that they were taken seriously by scholars. Yet, images and stereotypes created by European writers in the $19^{\text {th }}$ century continued, and remained in non-natives' perception. Anthropologists and ethnographers too are guilty of having mythologized Indians and created the "Indian that never was". During the various historical periods, the images changed in the way primitives, half-breeds, squaws, warriors, and militants were portrayed. In historian O'Garman's words, "Myths about Indians of the West seem impenetrable by facts, and in many people ... the stereotypes and misrepresentation remain safer than reality" $(2001: 3-4,7)$.

It is essential here to at least briefly address the issue of the stereotyping of Indian women. As with the representations and images of aboriginal people in general, those of Indian women too were voiced by 'others'. As with Indian men, a dichotomy has existed for centuries in the stereotyping of women. Valaskakis identified them as "beasts of burden or fetching maidens", as women who fall in love with traders, trappers, and soldiers. But it is the image of the "Indian princess" and the "Amazonian Indian Queen" in South America which has existed as a satirical picture in popular western culture for several hundred years. This Indian princess or queen was "draped in feathers and furs, carrying arrows and spears", the warrior woman and mother-goddess (2005:130). Pocahontas (which means "playful or mischievous") became the classic Indian princess, an idealized image of the Indian woman. Such female figures transformed several times between the 1500s and the 1800s. Sacajawea (or Sakaka-Wea - the "boat launcher", also 
called the "bird woman") who accompanied Lewis and Clark on their North American expedition, together with her infant-son, became another model Indian woman, imagined as attractively dressed, sitting in a birch-bark canoe, spearing fish with a bow and arrow (2005:125-126).

By around 1885, it served the Canadian government and the Canadian press to develop negative stereotypes of Indian women, especially those living on reserves. They were now portrayed as lewd, licentious, and responsible for much of the poverty and poor health that existed on the reserves. Such negative images became entrenched in society, especially those "of the most powerful socio-economic groups". The Indian princess who once aided white men "in a woodland paradise" had become "the squalid and immoral squaw", living in a shack, and her destruction was now seen as necessary for the sake of the advance of civilization (Carter 1997:160-161).

Another aspect of stereotyping Indian women pertains to their clothing which developed from pre-contact times right to the present. A one- or two-piece skirt or dress made of buckskin, some decorated with shells and beads made from clamshells or pine nuts, would be worn at ceremonial occasions (by people in the far West), together with basketry caps and forehead bands woven of cordage and feathers. In the early 1900s, new clothing styles emerged in which women created unique dresses (i.e. the Hathaway dress), increasingly using imported western materials and elaborate, colourful beadwork, particularly worn during public dances (Bates 1982:55-57, 60). I shall address the historical development of Indian women's clothing more closely in Chapter III.

According to Robert Berkhofer, in the past 500 years "the Indian of the imagination and ideology has been as real, perhaps more real, than the Native American of actual existence and contact" (in Valaskakis 2005:127). Bird raises the ultimate question on the issues of stereotyping native Indians: If their dominant cultural depictions are wrong, what would be right and perceived as positive? There is no straight-forward 
answer. Some Indians have taken advantage of the stereotypes, dressed in feathers for tourists in exchange for money, while others run gaming casinos or museums and cultural centres, using false, unauthentic artifacts and symbols for their own advantages. Some Indians oppose such "selling out", for others it has become a matter of "taking back power" (1996:7). Ultimately, it must be the native people's decision, how they wish to be portrayed by non-native societies.

To begin this debate, I shall devote the next chapter to presenting an overview of the history of North Eastern Woodland Indian culture, including material culture. It has to be understood not so much in the Western tradition of 'progressive' time but, in Cary Miller's words, "as recurring cycles, in the cyclical nature of the yearly subsistence cycle, ... in the cycle of time as related through prophecy" (1995:4-5), as well as the importance attached to dreams. It was through a Chief's dream that the Jingle Dress and Dance were conceived. Dreams and visions continue to be prominent in the lives of Indian women and men even in the $21^{\text {st }}$ century. Wearing an individualized regalia and dancing to a specific rhythm as 'seen' in dreams are integral to the processes of spiritual and physical healing. To follow the Woodland Indians geographically with the myth and belief of the Jingle Dance Dress, how and why the tradition moved from the west of the Great Lakes to the east, and back again, is explored in this chapter.

The third chapter will describe the origin(s) of the Jingle Dance Dress and provide an in-depth explanation of its semiology, with a 'side-glance' to other women's regalia, and to determine its social or spiritual links. The historical beginnings of the Jingle Dress, its emergence as a "symbol for healing" and thereby as a signifier of female power, beg the question of gender and of 'female Indianness'. Anthropologist Eleanor Leacock reported that some native women mistrust a separate study of women's roles "since they prefer to speak of their roles as complementary" (in Cavanagh 1989:56). Cavanagh, nevertheless, decided to examine the area "in which style or meaning may be 
differentiated by gender" in the way particular dancing steps are taken by the Algonkian women in contrast to men's styles in a similar dance, although the dance represented the same meaning for both sexes (1989:59, 61-62).

Chapter IV will focus on the transition and transformation of the Jingle Dance Dress tradition from its origin to the present. The early stories of jingle dresses mention 'jingles' without telling us what those jingles were made of, yet their purpose and symbolic meanings became known and became part of native women's consciousness as healers. Throughout the $20^{\text {th }}$ century, as materials for ceremonial regalia changed, undoubtedly, Aboriginal peoples' consciousness changed accordingly. In the $21^{\text {st }}$ century, specific questions arise: 'Will there be a continuity of the Jingle Dress tradition in the decades to come, one that will convey meaning and identity to the women and their children? Will it still hold the promises of spiritual, physical, and social well-being for the dancers and their communities? As some native women and men already perceive the Jingle Dress more as a trend, a 'fad' with modern trappings, not unlike mainstream Western fashion, with the sometimes high-kicking steps of the dance in mind, is a continued transformation even desirable? Can it possibly survive the 21 st century?

I will conclude by summarizing the findings of the foregoing analyses and attempt to determine what further research may be warranted. Semiological studies in the area of ethnic or aboriginal material culture may be as continuous or endless as the people who are rooted in it.

\section{Methods of Research}

As pointed out earlier, to most non-aboriginal people, to Western observers and to spectators at powwows, the Jingle Dance Dress, just as any other Indian regalia, seems no more than 'a pretty dress', of hardly more significance than a Sunday finery worn to church or to a party. However, anyone taking the time and effort to explore the various 
cultures will realize the dress' and dance's significant connection to the spiritual domain, their contact with the divine. The Jingle Dress and Dance were created specifically for physical and mental healing, meant also for those who are unable to dance for themselves, due to age or sickness. This ability to heal through song and dance is understood as a gift from the spirits which is granted only to certain individuals. My investigation into the Jingle Dress Dance tradition shall determine where and how it had its historical and spiritual beginnings. The matter of jingles and tinkles are explored, how they may be linked to the healing aspect of the dance and dress. After the tradition's decline and subsequent resurgence, especially on the powwow trail, the main debate lies in the question whether the current healing factor carries enough power, meaning and significance for Indian women and their communities to survive over the next several generations. Research has shown that the dress and dance are not always performed purely for healing purposes. One reason for this change is its immense popularity on the powwow circuit, especially among very young women, and even among children.

I am approaching this thesis from a semiological, empirical, and ethno-historical viewpoint. Textual and photographic research has revealed only scant, insufficient information about the Jingle Dance Dress itself (except in reference to powwows), especially during the period of the mid-1800s to the mid-1900s, although I have taken into account that the Jingle Dance Dress may have been named differently in its early stages. Extensive research at the Public Archives of Canada led only to a few late $19^{\text {th }}$ century and early $20^{\text {th }}$ century photographs of Indian women's dresses having been adorned with natural jingles such as deer-hooves or bird-claws, without any specific reference as to the function and meaning of the dress. A further search at the National Library (Ottawa) revealed no relevant information. Research at the Canadian Museum of Civilization (Gatineau, Québec) proofed more successful. Their archives included video material on the Jingle Dress and Dance at North American powwows, some sound- 
recordings of healing dances, though none in reference to jingle dress dances. The museum's library revealed extensive literature on the history and religious practices of the pre-history and post-contact North Eastern Woodland Indians, together with some links to their ceremonies; however, information on archaeological evidence of material culture was minimal. This may have been due to the fact that such materials, with the exception of some metal artifacts, do not survive the soil and climate of North Eastern US and Canada. As in the National Archives, the museum's photographic section included a few Indian women's dresses adorned with jingles or tinkles, though the pictures' explanations were inadequate to determine their actual significance. The museum's permanent displays exhibit one Ojibway jingle dress as well as two dioramas of an Indian hunter and a shaman wearing regalia adorned with rows of animal hooves and bird beaks.

I have interviewed two native women who are jingle dress dancers, and one native man during 2006. From May 2005 - May 2007 I attended, as an observer, three outdoor and two indoor powwows. The three outdoor powwows took place near Ottawa, while the two indoor powwows were held at the Odawa Native Friendship Centre (Ottawa). The latter also included a 'naming ceremony' for babies and toddlers, as well as one Jingle Dress healing dance for a sick child. Further interviews of jingle dress dancers at the powwows were unsuccessful. This raises the question, 'are non-native people (including students) too intrusive when observing or examining aboriginal ceremonies? I deduce a certain guardedness by Aboriginals in this regard. Internet searches, including those of anthropological museums showed only general information on the jingle dress and dance.

In November 2007 and January 2008 I had the opportunity to visit the Royal Ontario Museum in Toronto (Ontario) and the Museum of Anthropology in Vancouver (British Columbia). However, those visits and my communication with museum curators and other museum staff did not produce any more useful material on the Jingle Dance Dress. 


\section{The Matter of Terminology}

The term 'Indian', as it has been used for the last several decades by Indians and non-Indians, still seems to be open for debate. Francis explains that, as time passed and colonists' and Indians' contact became closer, Euro-Canadians' image of them changed over time. Such "contact revealed differences between the idealized vision of the noble savage and the reality of Native culture". While Whites began to invent a new identity for themselves as Canadians, the Other, the Indian, "was integral to this process of selfidentification". The Other stood for everything the Whites were not (Francis 1992:8). This image-change and self-determination on both sides eventually generated debates about the most appropriate or correct terms to be used. The most expedient and practical solution to the naming-issue therefore is to ask the people themselves, how they wish to be known. As Ames points out, even in the late $20^{\text {th }}$ century, indigenous peoples of North America are still struggling "to persuade others to call them by the names they call themselves" (1992:79).

D.L. Smith, a Winnebago and tribal historian, asserts that his people do not want to be called Native Americans since "everybody is native to this country". Being called Indians is a derogatory slang. Even Winnebago, which means "people of the filthy water", it not our name. Non-Indians should call us by our tribal name, in our case Ho-Chunk, which means "People of the parent speech - the first voice" (in Kohn and Lynwood Montell 1997:209). While most indigenous peoples in North America prefer to be identified by their band or tribal names, in Canada they collectively refer to themselves as First Peoples or First Nations (Herle 1994:57). No unanimity exists among non-Natives on the matter of terminology, and opinions also differ among native people, yet, they should have the final word by which name(s) they want to be known. Whichever terms they choose, in Adelson's words, it “is a claim to distinctiveness" (1997:291). 
In this thesis I shall, for the sake of simplicity, use primarily the term 'Indian' and, for the sake of variety, I shall also use 'Aboriginal(s)', 'native', and 'indigenous', as nouns and as adjectives. I shall refer to specific 'tribes' or 'nations' whenever these are known or relevant to the discussion. Here is a brief explanation of the differences between 'nations' and 'tribes'. A Native North American Nation is 'the sum total of a particular culture, life-style, and belief system of a group of people". Large 'nations' are "divided into tribes, or bands, or clans, depending on the history or language of the people, the tribes are further divided into villages", each village with its own Chief. For instance, the Sioux Nation is made up of tribes such as the Oglala, the Lakota, etc. (White 1996:8).

A last word on terminology is pertinent here. When researching and writing about 'Indian dress', there is a debate as to what describes a particular dress. Among scholars and aboriginal people themselves, the designations 'costume', 'regalia', 'outfit', or simply 'dress' are used. Sandra Ariwite, a powwow-dancer from Idaho, states, "Never call our powwow clothing 'costumes'. Clowns wear costumes" (in Roberts 1992:68). William Powers, on Lakota powwow costumes, explains that he prefers the term 'costume' to any other term since it is derived from the Lakota language. A costume refers to the special attire dancers wear at tribal and inter-tribal events. Lakota also differentiate between everyday clothes and those worn on special occasions (1990:67). 'Outfit' is another term often used by Indians, especially for those worn at powwows. Addie Many Chief (Blood Indian) remarked in reference to outfits that "we are taught to respect them, they are special to us and our families" (in Roberts 1998:47).

The most popular term in present usage is 'regalia'. However, Rossina (2000:5), in her thesis on the History of the Jingle Dress notes that, 'regalia' is gender specific and "generally used to describe male powwow dress" which also has military origins. The Concise Oxford Dictionary defines 'regalia' as "the insignia of royalty" and the "insignia 
of an order or civic dignity. As I would attribute a certain measure of royalty to the Jingle Dance Dress, as well as to other Indian clothing, and because of its present popularity, I shall use the term 'regalia' throughout this thesis when referring to all parts collectively, such as the dress, scarf, moccasin, legging, adornments and decorations. 


\section{CHAPTER II}

\section{NORTH-EASTERN WOODLAND INDIANS}

The purpose of this chapter is to present an overview of the prehistoric periods of the Eastern Woodland Indians. This is made possible by examining the archaeological finds in that region. These artifacts in turn provide information not only of the Indians' geographic movements and tribal distribution, but also present clues about possible links to their beliefs, rituals and ceremonies. The woodland environment to which the people had adapted is connected to their belief system as it evolved over millennia. Their unearthed artifacts provide proof of a meaningful ceremonialism. The chapter also addresses the Eastern tribes' early contact with Europeans, its relevancy to the formative history of North America, as well as its impact on Indians' future ceremonial life.

\section{Early History and Geography}

"At the initial point of contact, we were on the Eastern shore of North America. Since then, there has been a great decimation of our numbers, language and culture. In the average American citizen's mind, there is no Indian existence on the shore any longer, which is sad because once people get out and find the reality of our existence, and see that it's there, they are amazed at the durability, survivability, and sustainability of people who have been able to continue after so many hundreds of years and after so many attempts at devastation."

Donna Chavis [Lumbee] in Women of the Native Struggle (Bataille 2001:197)

When looking at a late $20^{\text {th }}$-century map, the major tribes that became known as the Eastern Woodland, are located from Indiana and Ohio in the south to as far north as Newfoundland, from the west of Lake Michigan to the Atlantic coastline. The main tribes occupying this vast area are the Ojibway, Fox, Iroquois, Ottawa, Naskapi, Montagnais, Micmac, the Penobscot, Cherokee, Creek, Menominee, Oneida, and Winnebago. Several hundred years ago, even more so a few thousand years ago, a map of those Indian tribes 
would have looked very different. With the help of archaeologists and some of the prehistoric and pre-European contact artifacts they discovered, an overall, though not entirely complete historic and geographic picture could possibly be drawn. Regrettably, there appear to be no complete archaeological maps which would tell us the exact distribution, geographically and culturally, of all prehistoric periods in the northeastern regions of North America. Brose, et al, suggest that mapping difficulties arose because some parts of the Eastern Woodlands were better known than others and therefore specially surveyed and excavated, while lesser known, often very small areas, did not attract the same attention. Also, archaeological evidence of the presence of people who lived in small, dispersed or highly mobile groups is quite sparse (2001:10-11). Attached, however, are two maps, one depicting somewhat crudely the geographic and cultural distributions of Indians in pre-historic Ontario (see Fig. 1), the other map showing PaleoIndian and Archaic sites in eastern North America (see Fig. 2).

Geographically, five different pre-historic periods define the human population, although archaeologists, who created these artificial devices to assist them in their studies, are not always in agreement as to the exact time-frame. There is overlapping between major pre-historic periods, as well as some fuzzy areas within these periods:

1. Paleo-Indian Period - 9000 - 5000 B.C.; or 10000 - 7000 B.C.

2. Archaic Period - $5000-1000$ B.C.; or 7000 - 1000 B.C.

3. Initial Woodland Period - 1000 B.C. - 1000 A.D.; or Early Woodland Period 1000 B.C. - 500 B.C.

4. Middle Woodland Period - 500 B.C. - 500 A.D.

5. Terminal Woodland Period - 1000 A.D. - Historic Period; or Late Woodland Period - 500 A.D. - Historic Period

(Wright 1972: H-Summary, 7; Storck 1981:1) 
When the first humans arrived on the American continent at least 30000 years ago, they were advanced enough to live and survive in a harsh environment. Much of eastern Canada was still covered by glaciers 11000 years ago. When the ice receded, people known as Paleo-Indians began to move into this ice-free area, attracted by the newly exposed land, lush vegetation and game such as caribou. They certainly had occupied Ontario 10 000-12 000 years ago, living along the shores of glacial lakes, tundra and spruce forest environments (Hensel 1993: 5-6; Storck 1981:4). There is some disagreement as to the artifacts found from this period. These people left no other evidence of their passing except for a few campsites and lance-shaped spear-points (Adams 1995).

This may have been due to Ontario's and Quebec's acid soil at that time which would have destroyed all implements except those made from stone, making the task of assembling the fragments of this period very difficult for archaeologists (Hensel 1993:6). R. and P. Ritzentaler (1970), however, mention that Paleo-Indians, occupying most of North America in small hunting groups, also left behind their very characteristic "fluted points" (spear points with long grooves, extending upward from the base on one or both surfaces). Other excavated tools they point to are scrapers, flake knives, and engraving tools, called "gravers". The oldest radiocarbon dates come from the Robert site in Nova Scotia, around 8600 B.C. $(1970: 10)$. Contributing to the confusion is Wright's assertion that, due to "evidence from an unglaciated portion of the Yukon Territory", humans were present as early as $25000-30000$ years ago. Yet, further south, such evidence is vague, certainly in Ontario, probably due to its sparse population at that time (1972:13).

As the climate became milder, more land became available for occupation. The long time between the end of the Paleo-Indian period and the time pottery was produced, is known as the Archaic period, spanning 65000 years (Adams 1995). Due to influences 


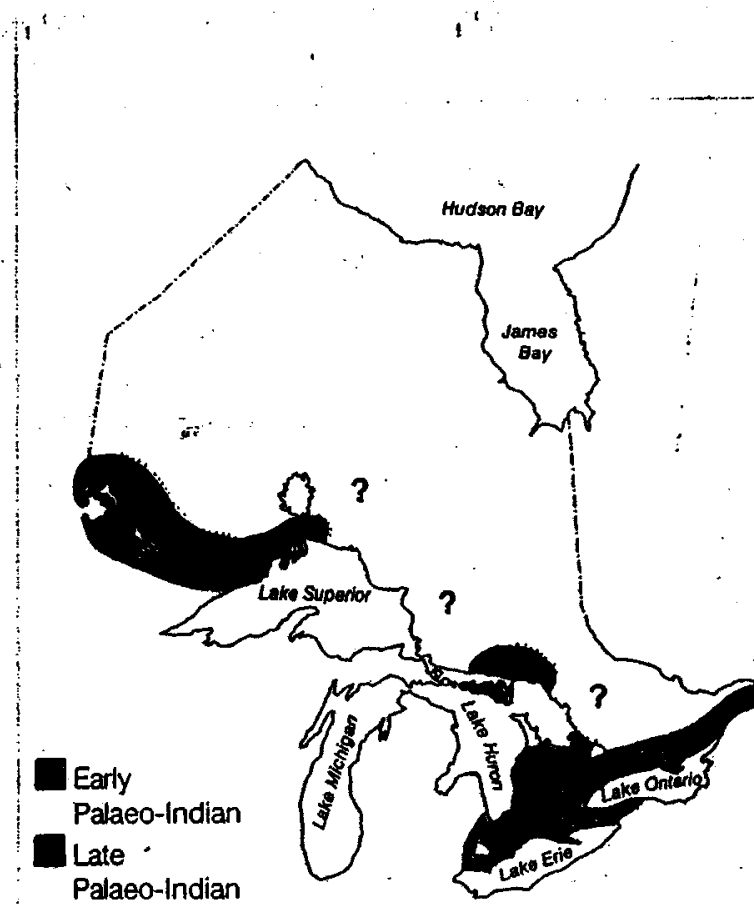

Distribution of Early and Late Palaeo-Indian peoples in Ontario during the Palaeo-Indian period.

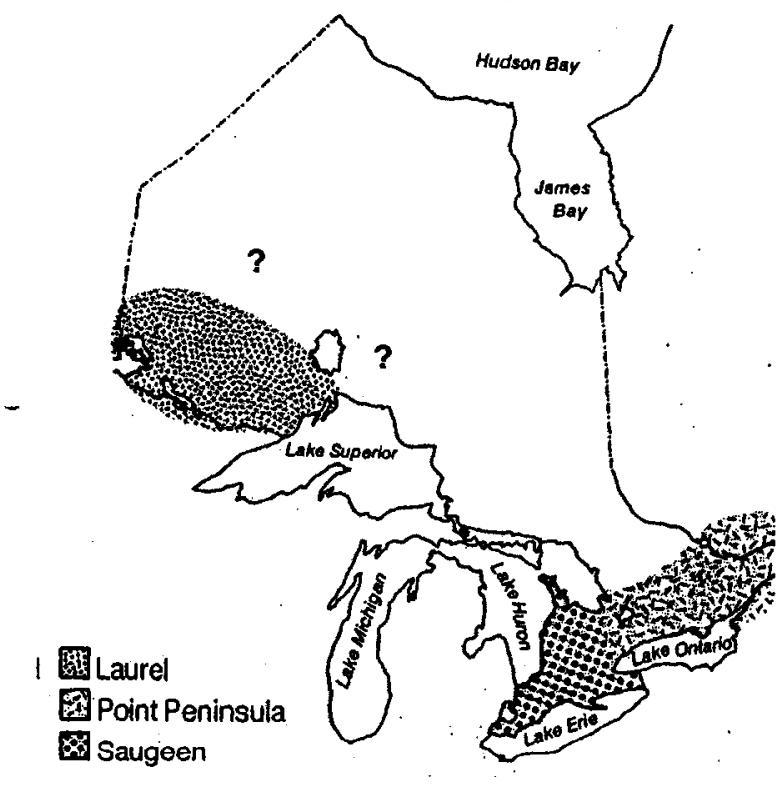

Distribution of Laurel, Point Peninsula, and Saugeen cultures in Ontario during the Middle Woodland period.

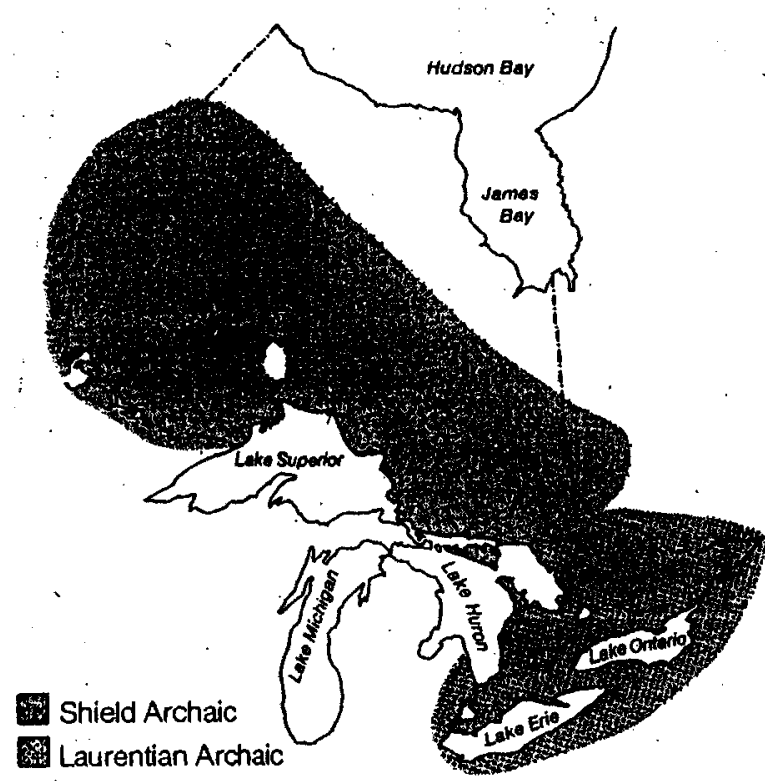

Distribution of Archaic cultural traditions in Ontario during the Archaic period.

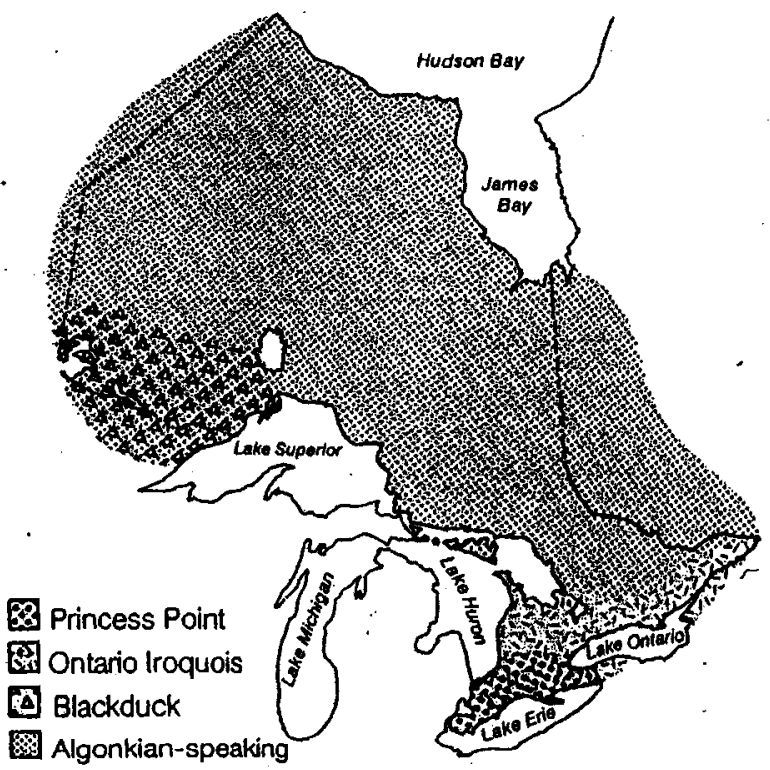

Distribution of cultural traditions in Ontario during the Late Woodland period.

Distribution of Eastern Woodland Indians istorck, Peter L., "Ontario Prehistory" (1981) 
Figure 2

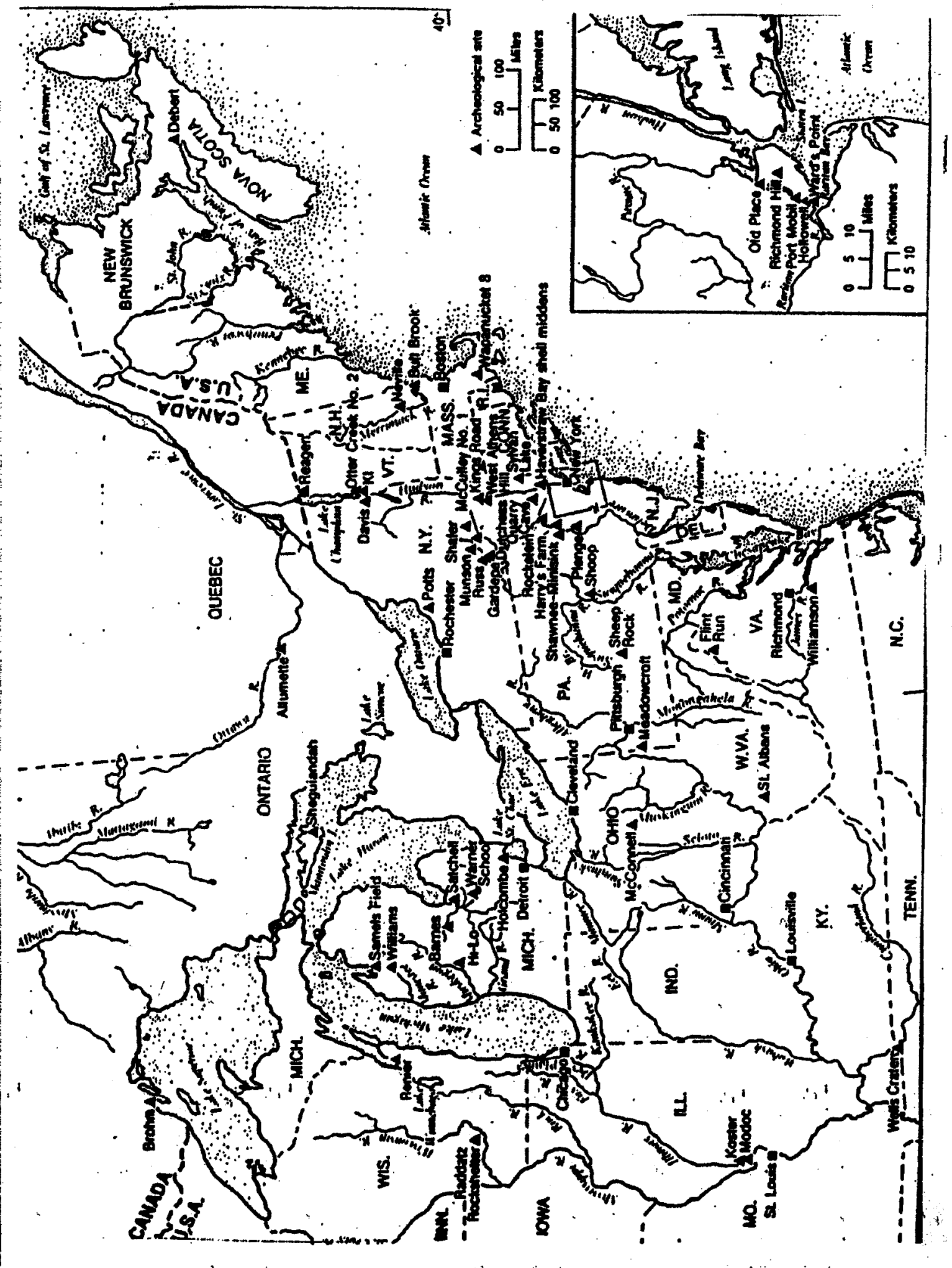

Paleo-Indian and Archaic sites

Sturtevant W., "Handbook of North-American Indians", voli.15, p. 17; 1978. 
from people in the south (south-eastern USA), the culture pattern in eastern North America changed and is known as the Archaic period. Weapons, hunting tools, and ornaments were made of slate and native copper. A culture called "Laurentian" was well established in eastern and southern Ontario, parts of Quebec, northern New York State, and Vermont by 4000 B.C.. Laurentian sites were discovered in the Ottawa Valley, especially on Morrison Island and Allumette Island (north of Pembroke), revealing several thousand artifacts of stone, bone, antler, and native copper. Although the Algonkian band and the Kichesippirini lived on Morrison Island at the time of European contact, it is unlikely that the Laurentian culture artifacts found by archaeologists belonged to the ancestors of that tribe, but more likely to the "Shield Archaic" culture. Such sites were found within the Canadian Shield. Tools and ornaments of stone and copper, and the red ochre found in graves were the only evidence. Since some sites also contained Laurentian Archaic artifacts, both cultures must have been in contact with each other (Hensel 1993:7,8). The copper tools found at Late Archaic sites were the earliest metal work produced in North America (Storck 1981:14). R. and P. Ritzentaler, in turn, identify the Archaic period through another series of cultures such as: "Old Copper, Red Ocher, and Glacial Kame". Lake Superior copper was cold-hammered into tools and implements with skill and diversity of forms unmatched by later Indians. Some of the groundstone objects were bannerstones, gorgets, and tube pipes (an early indication of smoking). Although there was no sign of agriculture at that time, some evidence of mound-building exists (1970:10).

Around 1000 B.C., a new idea spread among the Woodland inhabitants - using fired clay to make pottery containers. Although the technology may have had little impact on the people, it became of major importance to archaeologists. Pottery brakes and the broken pieces in the ground remain well preserved (Adams 1995). The people who 
adopted pottery were termed by archaeologists as the Woodland Indians. As a matter of classification, the Archaic Period transformed into the Woodland Period. This period, in turn, was sub-divided into Early-, Middle-, and Late Woodland periods (Hensel 1993:8).

Wright (1972:33) attributes the Shield culture to the Archaic population which had moved from the Keewatin District in the North West Territory to Cape Breton in Nova Scotia, while Hensel refers to them as early Eastern Woodland people who had also migrated into northern Ontario and western Quebec. These people first used pottery about 700 B.C. From this period, archaeologists relate to them as Laurel Indians and the Laurel culture. Some of their stone- and bone tools and implements which have survived were scrapers, hammerstones, net-sinkers, harpoons, arrowheads, lances, knives, snowshoe netting needles, and pottery markers. Native copper was used to fashion beads, bangles, awls, chisels and fish hooks (Hensel 1993:8). The Laurel Indians had considerable contact with other cultures and possibly were influenced by their neighbours to the south, i.e. southern Ontario, and especially the Adena people of the Ohio Valley (Adams 1995).

What distinguishes the Middle Woodland period from the Early Woodland period is the way in which the people expanded the methods of decorating their pottery, the shapes and types of their tools, the raw materials they choose, as well as the ways in which they were traded. Findings from numerous archaeological sites point, for the first time, to regional cultural differences. In Ontario, for instance, artifacts from the southwestern region contrast from those of eastern areas. According to archaeologists, during this period, "a vigorous culture" to the south, the Hopewell, existed. They buried their dead in especially-prepared earth-mounds with a variety of objects. Yet, not all people were buried in the same way which suggests the existence of a hierarchy or a class structure (Adams 1995). Storck, however, disagrees, pointing out that the Point Peninsula (Iroquois) people at the Serpent Mound site buried their dead with and without grave 
offerings. This indicated that social status was not a requirement for a mound-burial (1981:24). Hopewell cultures expanded over eastern North America, "uniting peoples with related beliefs and symbols". Their artisans worked with wood, stone, shells, bone, copper, sometimes with silver and gold. Their cultural exchange of materials and finished goods encompassed a trade network that stretched from the Mississippi and Illinois River valleys to the Scioto and Miami valleys in southern Ohio. Clusters of activity included Alabama and Florida (Dubin 1999:159). I shall return to the Adena and Hopewell in the next section on Woodland religion and ceremonies.

In order to be correct (or further confuse) the Woodland history, I want to mention here that J. V. Wright divided the Woodland periods, at least in Ontario, into just two periods: 1) the Initial Period; 2) the Terminal Period. In both periods he also refers primarily to the pottery culture and the moundbuilders, the Hopewell. He rejected the terms 'Early - Middle - Late' Woodland for the reason that this often caused confusion in the archaeological literature (1972:39-40).

By 900 A.D., when studying the peoples' pottery, a differentiation between Early Woodland and Late Woodland periods can be made. The conical-based pottery vessels, made by "the coil method" and decorated with different "forms of stamps", were now replaced with the "paddle and anvil method". The vessels were now beautified with socalled "cord-wrapped stick" decorations. But even more fundamental changes occurred during the Late Woodland period. After 500 A.D., maize was introduced from the south (Meso-America) and over the next few centuries, the cultivation of corn, squash, beans, and tobacco gained importance. Although fishing and hunting still continued, this transition from a lake- and forest-based economy to an agricultural one also hastened cultural and technological changes (Adams 1995). Settlements adjacent to cornfields and sources of water gradually became more permanent. At first, the development of 
agriculture in southern regions such as Ontario, had little impact on northern Indian populations. Late Woodland people in the north lived much as their Middle Woodland forebears, yet adopted many of the technological changes that had occurred in the south and applied them to their northern climate. There is abundant evidence of contact with Iroquois and other agricultural groups in the south (Bursag $e t a l$, n.d.).

The following millennium, 500 A.D. -1500 A.D., up to European contact, still belongs to the Late Woodland Period. The Adena and Hopewell cultures which became prominent during the Burial Mound periods (from ca. 1000 B.C.), ended around 700 A.D. After about 750 A.D., three environmental zones bordered the southern shores of Lake Erie: "the Glacial Lake Plains, the Central Till Lowlands, and the Glaciated Allegheny Plateau" which correspond to north-western and north-central Ohio, north-eastern Ohio through north-western Pennsylvania and north-western New York state (Banks et al in Brose et al 2001:49). These environments distinctly determined the aboriginal peoples' social and cultural lives in those regions, from the late prehistoric to the early historic times.

Long, warm summers with adequate rainfall and cool, dry winters after 800 A.D. grew even warmer and moister, and the winters increasingly drier after 1000 A.D. This extended the agricultural growing season along the lakeshore. These Late Woodland people lived in small seasonal camps, consisting of a few circular houses. Their chipped stone points and differences in their ceramic traditions correspond to the environmental zones mentioned before. After 750 A.D. they buried their dead in large, regional cemeteries, together with such objects as ceramic pipes (Brose et al in Brose 2001:49, $51)$.

Before approaching the period of first contact between East Woodland Indians and Europeans, it needs to be pointed out that the major tribes which had evolved were 
the Iroquois and the Ojibway. These two tribes or nations will be the main focus of the next chapter on the Jingle Dress and Dance tradition. The Iroquois of Ontario could be traced historically, ethnologically, and archaeologically to approximately 900 A.D., exceeding any other Indian culture (Wright 1972:66). Theories about the "local origin" of the Iroquois vary, such as long-distance migration, followed by in-place development. It is, however, certain that by 1500 A.D., Iroquois-speaking peoples of the North-East had formed cultural characteristics for which they became known in the historic period (Tuck in Trigger 1978:322; Trigger 1978:344). Extended families joined into clans, living in villages of at least one-thousand people; linked together with neighbouring villages, they formed tribes. They lived in longhouses and subsisted mainly on horticulture, hunting, and fishing. In this late prehistoric, near contact period, the Iroquoians were spread out over a large area, stretching from western Lake Ontario to the south-east of Lake Erie, beyond the Niagara River to upper New York state, and as far as the Mohawk River valley, as well as further south along the Susquehanna River to the Saint Lawrence lowlands. Archaeological records show that inter-tribal warfare was quite common, but trade was restricted to such "luxury items as native copper and marine shells". Whether any political units existed is uncertain; nevertheless, the Hurons later claimed that they had founded their confederacy around 1400 A.D., though this is based on a vague oral tradition. The Iroquois Confederacy at that time involved nothing more than tribal agreements to contain blood feuds and raids (Trigger 1978:344).

In the area from southern Ontario to south-western New York, the "Ontario Iroquois" had developed quite a homogenous culture during the century of 1300 A.D. 1400 A.D., such as the "elaborate pipe complex" and the beginnings of cannibalism. By 1400 A.D., the four historic tribes - Neutral, Erie, Huron, Petun - had begun to evolve (Wright 1972:75). I shall refer here only briefly to the Five Nations Iroquois Confederacy. 
Consisting of the Seneca, Cayuga, Onondaga, Oneida, and Mohawk, their prehistory appears to be "characterized by the in-place development of all five tribal groups" (Trigger 1978:322). When exactly the Confederacy (or League) was established is still a scholarly debate; however, according to the Iroquois tradition, it was founded long before Europeans first came to their country. What were the reasons for its founding? Those five tribes had been at war with each other over a long period of time. To end the conflicts, the Great Peace, the Confederacy of the Iroquois was created, calling themselves the People of the Longhouse. The most western tribe, the Seneca, designated the Keepers of the Western Door, the Mohawks, as the most eastern tribe, the Keepers of the Eastern Door. "The other tribes were arranged in a line between them", an "arrangement of families of their fires in the ordinary longhouse". Thus, the Iroquois called it also "the confederacy of five fires"; later they termed the United States "the thirteen fires". This Iroquois of the League greatly influenced history in the $17^{\text {th }}$ and $18^{\text {th }}$ centuries. Who would ultimately control North America depended greatly on the Iroquois' decision whether to ally with the French or the English (Tooker in Trigger 1978:418). For over 150 years, the Iroquois were "the force to be reckoned with, by natives and colonists alike" (Axtell 1981:xvii). Prehistorically, the second-largest of the Eastern Woodland tribes, the Algonkians, occupied the area northeast of Lake Superior to the Manitoba border, the northern area of Hudson Bay and south to Lake Abitibi (Storck 1981:26-27). The western part of this region was occupied by Algonkians of the "Blackduck culture" which dated from about 800 A.D. -1400 A.D., an outgrowth of the Laurel culture of the Middle Woodland Period. Archaeologists, however, are not in agreement whether the Blackduck people were Algonkians or a small "Siouan enclave" in a region which the Algonkians dominated. Blackduck pottery is "decorated with deep impressions made with a cordwrapped stick and punctates made with the end of an object such as a blunted piece of 
bone or a reed". They buried their dead in graves or placed them on scaffolds in trees. Occasionally, the bones were placed in mortuary vessels, then reburied in earthen mounds (Storck 1981:27).

Perhaps due to the fact that archaeological knowledge of the Algonkians (at least of northern Ontario) is still somewhat limited, Wright criticized the heavy reliance on ceramics to determine culture and history. In the case of the Iroquois, archaeologists suggested that "tribe and dialect roughly correlate with ceramic style". Algonkian evidence, however, suggests that ceramics were "a borrowed element" and not strongly integrated in the aboriginal culture. Nevertheless, pottery styles helped in tracing outside influences Algonkian bands had received. Another pottery tradition, known as Selkirk, dominated the northern area, producing not only pots, but also bowls and plates (1972: 92, 102).

In northern Manitoba, the northern Algonkians can be traced from the historic period to the $10^{\text {th }}$ century. Approximately the same timeline ("time depth") has been recorded for the western and eastern Algonkians and those who occupied northwestern North-Ontario. The latter, though, developed a different ceramic tradition. Their ceramics were discovered from east of the Ottawa valley to the north-shore of Lake Superior. When looking at the stone- and bone tools only, one can regard the eastern, western, and northern Algonkian areas as a single archaeological network, reinforced by "occurrences of rock paintings and boulder constructions". The pottery traditions proved useful in dividing the vast geographic regions of the Algonkians. The cultural and linguistic similarities among present Algonkians are certainly reflected in their prehistory (Wright 1972:102-103).

It is fair to state that, historically, in Axtell's words, the Indian tribes of the East, especially of the triangle between the Carolinas, the western Great Lakes, and the 
Canadian maritime provinces, were of greatest relevance to the formative history of America. They met the European explorers and colonists who scouted the Atlantic coast, then pushed their barks into the lakes and rivers of the interior of North America (1981:xvi). When Columbus arrived on the American continent, the Woodland Indians were occupying a huge forested area, "extending from the Mississippi River eastward to the Atlantic Coast and, roughly from a line north of what is now Tennessee into most of the eastern half of Canada", all sharing a similar language and culture (R. and P. Ritzentaler 1970:1). (see Fig. 3)

Before I proceed to a discussion of 'Beliefs, Myths, and Rituals', I want to let the East Woodland peoples themselves speak of their long migration stories which have become a vital part of their oral traditions. For the Ojibway,

"The past was a visual memory and oratorical gesture of dreams plaiting an endless woodland identity between the consciousness and unconsciousness worlds of the people" (Valaskakis 2005:110). "In Chippewa heritage , the journey through which the people became a nation begins at the eastern shores of North America", where they were numerous and powerful; one could climb the highest mountain, look around and not see the end of the nation" (Benton \& Benai in Valaskakis 2005:110-111).

As their Elders told, carrying the sacred fire for hundreds of years, the people moved through the waterways of the St. Lawrence River and the Great Lakes, "stopping at locations signed in the sacred Egis shell of the ancient Madden religion and claimed in the Chippewa rock carvings of spirit beings". They at last settled in areas now known as Ontario, Minnesota, Michigan and Wisconsin. In this journey, "deep in the vague discourse which maps the title to Chippewa territory lies the Anishnabe belief that they are the original people of the woodland ..., that they were given wisdom and life colour from the sun reflecting on the sacred shell during the long migration". The Elder reminded them that they are Anishnabe, the original people, "spontaneous beings created 
by the Great Spirit" (Vizenor; Whaley \& Bresette, in Valaskakis 2005:111).

Such narratives of the Chippewa and of other Nations - of "where we all come from" - tell of movement that was so much part of the Indian life of earlier times until they were relegated to reservations centuries later.

The Indians lived and travelled according to seasonal cycles to hunt, trap, gather maple syrup, wild rice, and trade with other people. While Plains Indians followed the buffaloes, and coastal Indians moved to new fishing grounds, Iroquois farmers moved their villages so the soil could renew itself. Besides those essential movements, all nations travelled to ceremonies, social gatherings and sacred sites (Valaskakis 2005:111).

As pointed out, those journeys of ancient times by the East Woodland Indians were primarily forced on them by seasonal activities and environmental forces which shaped their unique lifestyles over the millennia. The forced movement that was still to come after their contact with Europeans, the Woodland people could never have foreseen. During the healing ceremony of a Ghost Dance in 1889, the Paiute spiritual leader Wovoka made the prophesy that "the time will come when the whole Indian race, living and dead, will be reunited upon a regenerated earth, to live a life of aboriginal happiness, forever free from death, disease and misery" (Mooney in Valaskakis 2005:165-166).

\section{Beliefs, Myths, and Rituals}

R. and P. Ritzentaler are correct in telling us that the Woodland Indians' world was one filled with spirits and ghosts, though without providing us with a timeframe and associating evidence. They explain that plants, trees, birds, rocks, and animals inhabited spirits, that cosmic phenomena such as the sun, moon, the four winds, thunder and lightening, were of major importance. The Woodland people believed in benign and fearsome ghosts like the Windigo, the water monster (a cannibalistic giant) who stalked 


\section{EUROPEAN ENTRY INTO NORTH AMERICA}

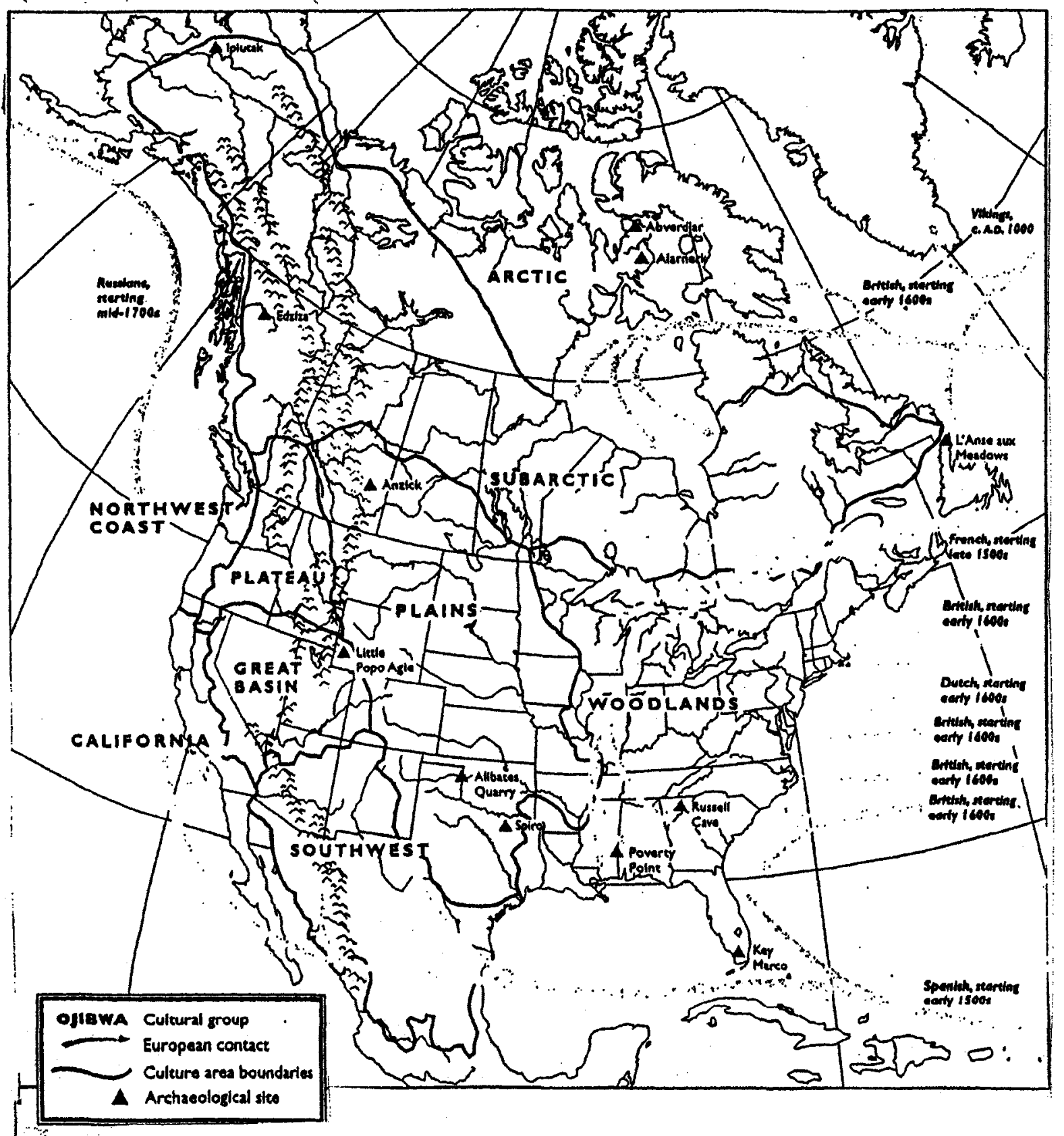

Dubin, I.S., "North American Indian Jewelry and Adornment From Prehistory to the Present". New York: Harry N. Abrams, Inc. (1999) 
the woods; there was the demigod Wenebojo or Manabush, a trickster as well as "bringer of good things" who had taught the people about maize, tobacco, and medicinal plants (1970:87).

To find evidence of some of those religious beliefs, we have to return to the Burial Mound and Temple Mound periods (ca. 1000 B.C. -700 A.D. and 700 A.D. -1700 A.D. respectively) which succeeded the Archaic Period and includes the Adena and Hopewell cultures. A "cult of the dead" was central to these Woodland cultures so that a great deal of labour was devoted in the construction of the mounds and of the burial rites. Excavation sites in southern Ohio, Indiana, northern Kentucky, and the largest in Virginia (Grave Creek Mound), revealed that these mounds, or earthwork enclosures, served ceremonial purposes. They were usually circular, some rectangular, averaging 100 metres in diameter, roofed over with wooden poles and bark, then covered with a mound of earth. Other tombs were often built in or on the mound and covered with more earth (Willey 1966:269-270). In some parts of the US such as Wisconsin and Ohio, earthworks were discovered in human forms and animal forms, for instance a double-headed man, a frog, a bear, a bird with outstretched wings, and a turtle, ranging in length from 17-46 metres. The largest earthwork is the Great Serpent Mound in Ohio with a length of 405 metres. When, from 1900 into the 1930s, these mounds were scientifically investigated, it became clear that many different populations at different times and for different purposes had erected them (Ceram 1978: 232-233; my translation).

The large artifacts found in the mounds were not only of a secular nature such as tools, hunting weapons, and adornments, but also of the sacred and spiritual type linked to the Woodland peoples' beliefs and myths as mentioned before. Adena stone tablets engraved with images of birds, one with a hooked beak and long talons, one with human hands as wings; a Hopewell copper- and mica cut-out plaque, depicting predatory birds, a 
horned serpent carved of slate, decorated stone pipes, one pipe in the shape of a bird, together with a decorated small jar of polished monochrome on which the pipe rested. There were frog-effigy jars from the Mississippian mound tradition, and a stone pipe in the figure of an ocelot, as well as numerous other sacred mound artifacts (Willey $1966: 271,275,299,303)$.

Due to the 'visual fact' that most parts of the south- and northeastern Woodland areas are dotted with hundreds of burial- or temple mounds, it is of considerable interest to note how these mounds had been perceived by European travellers and armchair scholars during the $18^{\text {th }}$ and $19^{\text {th }}$ centuries. The beginning of the "myth of the moundbuilders" in North America was traced back to 1785 and continued into the $19^{\text {th }}$ century. Those Europeans asserted that the mounds could not have been built by the native people or their ancestors, only "by a more civilized and populous race" which disappeared long ago. Native Americans were believed to be savages, not capable of such undertakings. Two hypotheses had emerged: the moundbuilders and the Indians were the same people, or the moundbuilders were an ancient race, extinct or moved away, and then replaced by a later population. These 'literate observers' could detect no links between contemporary natives and the mounds. Yet, one exploratory party in south-eastern US (de Soto's) actually observed Indians building and using mounds, but these data were soon forgotten. Speculations continued, many more observations were made, artifacts unearthed, new and better data emerged. Still, the myth had not died. Published material now suggested that the mounds were built by Danes who migrated to Mexico "and became the Toltecs". In the late $18^{\text {th }}$ century, army men stationed in Ohio made useful contributions through letters and maps. Many public figures, including politicians, became immersed in the myth of the moundbuilders in the 1800 s when the "lost race" hypothesis was the most widespread (Willey, Sabloff 1993:22-25). 
My elaboration on the burial sites and templemounds I believe to be justified since they are among the oldest evidence of the spiritual lives and ritual practices of the Eastern Woodland peoples. The mounds are unique monuments in North America and of vital cultural and spiritual importance to the people who built them. What appears to be absent is any sign or archaeological evidence of the moundbuilding peoples' (i.e. the Adena and Hopewell) 'song and dance' culture. The literature I consulted does not mention any. Since Eastern Woodland peoples' cultural expression is vibrant in so many forms to this day, it seems inconceivable that feasts consisting of ritual dancing, music, chanting, would not have been important in their lives even in those ancient times. Where are the remnants of drums, flutes, rattles, etc.? Could they all have 'vanished' into the earth inside the mounds? Natural products made from shells, copper, or stone are decorated or engraved with numerous symbols, none, however, depicting such activities as ritual dancing or singing; also shamanism seems to have been absent in those early times. On the other hand, Ceram's volume Der Erste Amerikaner (1978) includes drawings of reconstructed Hopewell hair-styles and hair ornaments, based on excavations in Illinois. Hyde (1962:31) mentions antler headdresses, pearl necklaces, copper bracelets and other ornaments, indicating that Woodland people 'dressed up for the occasion' (see Fig. 7). Obviously, the mortuary aspects of the mound-culture was rich and splendid, too vast in space and time for this thesis.

As the people of the mound periods had turned their eyes heavenwards, searching for new gods, gods in the sky, and began to believe in a life after death, Indians in the north still had faith in "earthbound animal gods". When the "sky-deity" religion of the moundbuilders began to spread from the Ohio Valley to the northern Indians beyond the Grates Lakes and the Mississippi, it became a powerful force. This 'cult of the dead' and 'feast of the dead' with its strong belief in a future life they had then adopted, was still 
strong in the $18^{\text {th }}$ century. Even sixty years ago, scholars talked of sun worship, sun priests, sun kings among the Indians in those times. Seventeenth-century Jesuits termed the Hurons of Ontario and other northern tribes "sun worshippers".

Mound-building and cremation, the two main characteristics of the Adena culture, was never practiced among northern and northeastern Indians. The Iroquoians especially retained their own beliefs and customs (Hyde 1962:17, 48, 49, 25).

It seems obvious that the early 'armchair explorers' had no direct contact with the Eastern Woodland peoples to enquire about their mound-building ancestors. But some of the early avocational and professional archaeologists and ethnologists began to communicate with some tribes. Hyde mentions the Skidi Pawnees who had "a clear record of sun, moon, and star worship", and of human sacrifices to Morning Star, that they migrated westward from the Ohio after 1650 , and that their religion was close to that of the Ohio moundbuilders. The New York Iroquois knew myths of a Sky World which became the basis of their religion (1962:49-50). The Delaware, a tribe of the Ohio moundbuilders, told of an ancient song which they recorded in their "Walam Olum or Red Score" about tribal migrations and wars. They painted tribal events on birchbark or wood in the form of pictographs, though probably after their contact with Europeans occurred around $1600 \mathrm{AD}$. Their Walam Olum presents a "blurred memory" of their history back to the year 1400 . Hyde points out other narratives of Eastern Woodland tribes' migrations and contacts with various tribes whose way of life still had links to that of successors to the moundbuilders (i.e. the Siouans, Omahas), but whose religion also featured sky spirits and animal gods. It is also known that the Omahas and Osages continued their mound-building traditions well into the $18^{\text {th }}$ century $(1962: 55,68,70)$. Nevertheless, it appears that many tribal events were based on speculation, some on native narratives (i.e. the Walam Olum), while others can be substantiated through 
The Mounds are dêciphered

Male (A) and female (B and D) hair ornaments of the Hopewell people. C depicts the style of a nursing mother, $\mathrm{E}$ and $\mathrm{F}$ ornaments are Indian forerunners of a Cul de Paris, made from the tailfeathers of a turkey. (my translation)

Die Mounds werden entraetselt Männliche $(A)$ und weibliche ( $B$ und $D$ ) Haartracht der Hopewell-Menschen. C zeigt die Tracht einer stillenden $M$ utter, $E$ und $F$ sind Turnüren, indianische Vorläufer eines Cul de Paris, aus den Schwanzfedern des Truthabns.
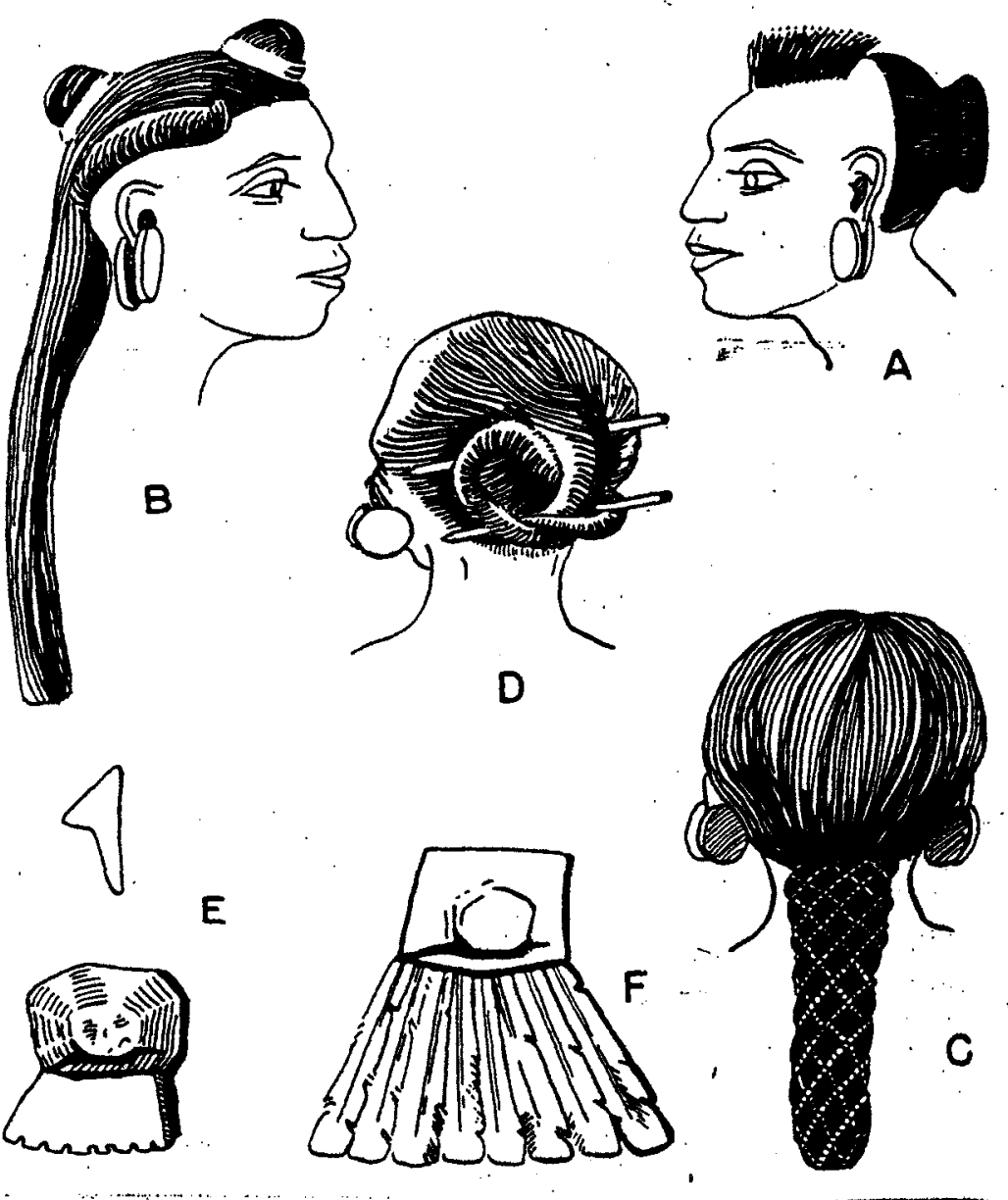

Ceram, C.W.,"Der Erste Amerikaner", Reinbek bei Hamburg: Rowohlt Verlag GmbH (1978) 
archaeological records. Hyde's remark that the disappearance of the moundbuilder culture "is an even greater mystery than the puzzle of its origin", somewhat contradicts his statement that the end of the moundbuilder civilization (at least in the Ohio valley) came with the arrival of the Europeans since they brought chaos, wars, diseases and caused further migrations $(1962: 51,50)$.

\section{The Iroquois Longhouse Religion}

At this point in Eastern Woodland history and culture I want to return to one of the two major tribes, the Iroquois of the St. Lawrence and Ontario (the other being the Algonkian). Missionaries and explorer who lived among them during the first half of the $17^{\text {th }}$ century left us with considerable written records, surpassing that of any other native culture in eastern North America. The ethnological and archaeological evidence already begins in the $10^{\text {th }}$ century with the so-called Pickering and Glen Meyer populations (Wright 1972:66). Then, at the "edge of the historic period ", when the Iroquois population and their villages were large, they were driven from the land along the St. Lawrence and migrated south into central and northeastern New York. The Iroquois legends collected by Perrot and Colden in the 1600s told of the Hurons who then possessed the former Iroquoian land east of Lake Huron. This is where Cartier met them in 1545. This legend can be backed up by some archaeological evidence. Distinctive St. Lawrence Iroquois pottery was found on those mid-16th century Huron sites (Wright 1972:90).

Originally peaceful people, the Iroquois eventually became serious warriors, in fact masters of this new profession. The Mohawks, the Iroquois tribe farthest to the east, were the fiercest fighters. By about 1570, the "wise men" Dankanawida and Hiawatha persuaded the Iroquois to cease fighting and to form a league. This is usually given as the time when the 'Iroquois Confederacy of the Five Nations' was founded, although there 
are some inconsistencies among scholars and the Indians themselves as to the exact time (Hyde 1962:85-87). According to Wright, the Iroquois Confederacy's founding predates the arrival of Columbus, 150 or 200 years before the Iroquois met the Europeans, in accordance with the "traditions of the Iroquois themselves" (1993:115); Tooker suggests just before 1400 , or just before 1600 , or one generation before the white people arrived (in Trigger 1978:420). Wright does not mention the Iroquois 'warrior life-style', but attributes the union of "five related peoples" to political frictions brought on by farmingprosperity, population growth and increasing power which stretched from Lake Ontario (Onhatariyo in Mohawk language) to upstate New York. The confederacy's influence eventually extended from Québec to Kentucky, and from Pennsylvania to Illinois, experiencing its height during the $17^{\text {th }}$ and $18^{\text {th }}$ centuries (1993:115). (see Fig. 4)

This confederacy became not only a political but also a spiritual force. "The Iroquois conceived of their union as a great Longhouse with five (later six) partitions". A symbol of Iroquoian identity, the longhouse was a hut constructed "of arched poles and neatly stitched bark". In pre-historic times they were the homes of a clan mother, her female kin and children. A totem animal would have been carved above the door. Each of the six Nations bore a certain longhouse responsibility such as Keeper of the Fire, symbolizing government; Keeper of the Doors responsible for defense, etc. Today, however, longhouses are "purely ceremonial" (Wright 1993:118). As a further archaeological testimony, the author refers to the foundations of a 334 feet-long building, situated in the Onondaga Valley, south of the present-day city of Syracuse. Radiocarbondating tells us that this longhouse was built at least a century before Columbus. Near Onondaga Creek is a 7,000 acre reservation, in the middle of which stands a new hall, made of logs. Although it is only one-third in length of the ancient one, in Wright's words, "Here sits the oldest living parliament in the Americas, and one of the oldest in the 
world." (1993:118) (see Fig. 5).

The members of the League would meet periodically for common benefit and to settle feuds. The "Peacemaker, a divine hero", would appear from a white canoe, and interpret his Great Law to the feuding Iroquois. He created a Confederacy Council of 50 sachems, chosen by clan mothers. Elected for life, women could depose them. The Iroquois themselves wrote down the accounts of the League on wampum belts, which are documents partly constitution, partly mythology "in which governance is sanctioned by holy revelation" (Wright 1993:118-119).

As mentioned before, the Great Law of the Confederacy had its political, spiritual, and ritual significance. Like all North American Indians, the Iroquois felt an intense gratitude for the "gift of life" which was expressed in ceremonies throughout the year. Individual dreams and visions too were of great importance; they coexisted alongside the numerous rituals. Dreams would signify what needed to be done to maintain good luck and good health. In spring, the Maple Feast was a family celebration around their sugar groves, and a Planting ceremony after the seeds were planted. When the first wild fruits were tasted, the Strawberry Feast was held, followed by the Green Bean ceremony. Their highlight was the Green Corn Dance once the maize was ripe. Finally, during fall, after the crops were gathered and stored, the people honoured the Creator with a big Thanksgiving Feast. To conclude the old year and begin the new, the Midwinter ceremony was the longest and most important of all ceremonies. It was a time of renewal. Annually, but less frequently performed, were the Sun, Moon, and Thunder ceremonies (Tooker 1979:268-270; Wright 1993:121).

At Midwinter, Tooker goes on to explain, old dreams and old cures are renewed. When a sick person had such a dream, the medicine society would perform a ritual for the benefit of that patient. When the individual is cured, s/he is expected to sponsor a dance 


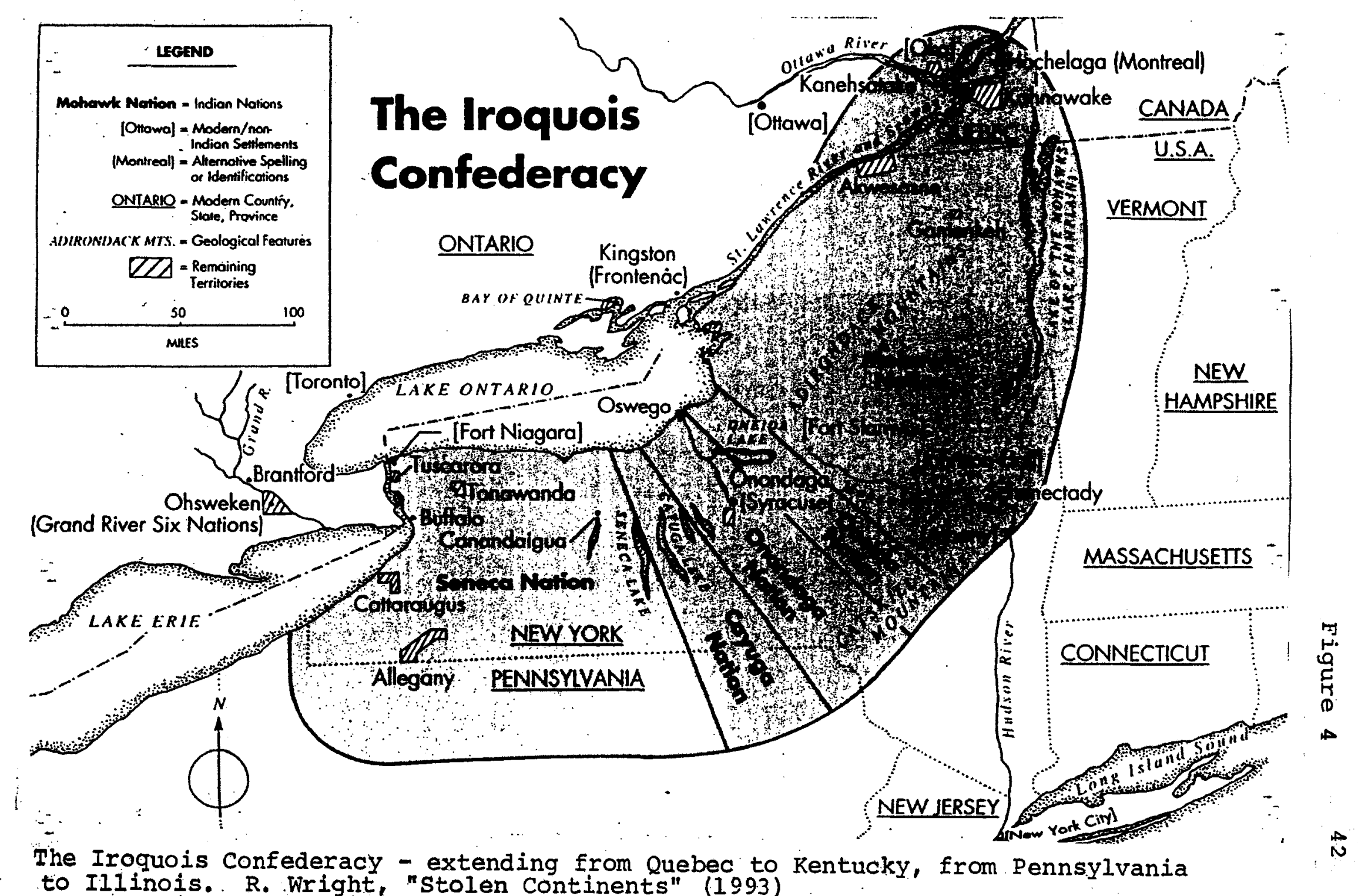


Eigute 5

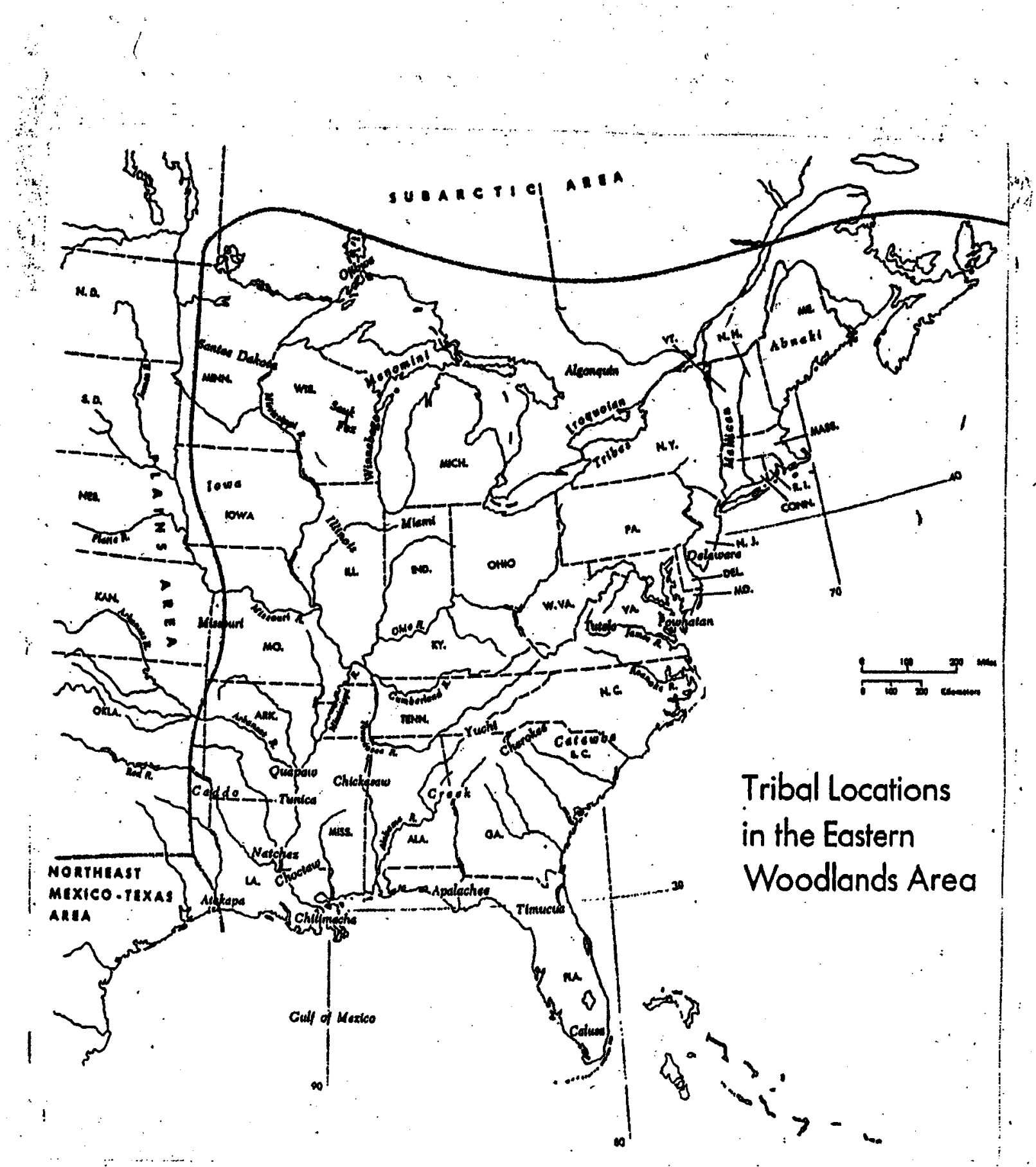
G.R. Willey; "An Introduction to American Archaeology"
(I993) 
for the members of the medicine society. The ashes-stirring rites, stirring the ashes of household fires, extinguishing old fires, and rekindling new ones, are also part of the Iroquois renewal-theme at Midwinter. The tobacco prayer, "once said over the white dog that served as a messenger to the Creator", asks the Creator for good luck to continue in the new year. In a sense, these cyclical Iroquois ceremonies and rituals recognize the Creator's continued assistance (1979:170).

The information on Iroquois ceremonies in Tooker's volume is based on oral presentations which were recorded and transcribed into texts 50-75 years ago. They were written interchangeably in the past and present tenses, so the reader is unsure which rituals, if any, were still being practiced by the Iroquois in the late $20^{\text {th }}$ century. She states that some of the rituals were already "moribund" at the time of recording, but we do not know which ones they were.

Abner and Tooker inform us that, despite the decline of the Longhouse Religion since 1890, three Longhouses (Tonawanda, Newtown, Coldspring) still serve the Seneca of New York State to perform the old Iroquois ceremonies. The yearly cycle of festivities include the preaching of the Code of Handsome Lake, the Midwinter ceremony, as well as planting and harvesting feasts. Sun, Moon, and Thunder ceremonies have become quite rare (in Trigger 1978:514).

Since healing and medicine ceremonies will be one of the focal points in the next chapter, I briefly want to describe 'The Little Water Ceremony' of the Iroquois. It is based on the myth (time of origin is not stated) about a young hunter who, while hunting in the forest one day, was badly wounded by enemies and left for dead. Because he had always been very kind and loving to the animals of the forest, they came together, concocted a powerful medicine to which a small amount of water was added. The young man was revived and was now able to understand the animals' and birds' language and songs. To 
show his gratitude, the animals requested that he perform a ceremony and sing their song whenever people needed a favour. The Little Water Ceremony had been recorded at Tonawanda (south of Lake Ontario) and published in 1959 by Edmund Wilson (Snow, 1994:218-220). The author does not mention whether this recording was the only or the last one of this particular Iroquois ceremony.

\section{The Ojibway (Chippewa)}

The second major Woodland group, the Algonkian-speaking people, are grouped into three major divisions -- Central, Eastern, and Subarctic (the Iroquoian-speaking tribes making up the fourth group). Each group is further divided into sub-groups (R. and P. Ritzentaler 1970:4). My main, though not exclusive, focus among these groups will be directed towards the Ojibway. Since the Jingle Dress and Dance tradition appears to have originated with them, they will be at the centre of Chapter III.

The Algonkian-speaking peoples were the first who greeted the whites and encountered white settlers, teaching them how to survive in their new environment $(R$. and P. Ritzentaler 1970:2-3). Their migration had began from the country west of Lake Superior towards the south and east, holding both shores and the north of the Great Lakes. Hyde points to modern archaeology "which clearly indicates that the Algonkians have also occupied the territory from Labrador south into New England at a very early period", and some even migrated as far as Virginia and the Carolinas (1962:3).

The Algonkians' myths, beliefs, and ceremonial life is as unique as that of any other Woodland tribe. Their early beliefs and practices were similar to those of most North American cultures, especially those of the Iroquois. A rough overview of Algonkian-Ojibway religion told of a belief in the "Great Spirit who presided over the earth from above, near the sun". In pictographs, this spirit sometimes is portrayed as the sun. The Great Spirit represented kindness and goodness. The people believed that 
everything in nature had life, soul and spirit. Each spirit had a power, such as the bird's spirit had the power of flight, being able to see from the sky. In addition to the good sprits, evil ones were present too, those deep down who "caused rough water", and supernaturals like the Windigo who "ate human flesh". To please and thank the spirits, people would pray to them and offer smoke from the pipe (Page 1982: 95, 30-31).

But to understand the Ojibway spiritual world or religion, one needs to consider the major influence that dreams have on their lives. An aged Ojibway once said that "in the old days our people had no education", no books to learn from, so "all the wisdom and knowledge came to them in dreams". They learned from early childhood to test and cultivate their dreams, most of all to always remember them. A child learned very early "to see something extraordinary in sleep". Even if the dreams were insignificant, a child was being prepared for the important dreams once it reached adulthood. This was the same for girls as for boys. For the revelation of one's guardian spirit, "purity of life and thought" was necessary, while fasting and meditating were principal conditions to secure such a dream (Densmore 1970:78-79). According to the Ojibway, they often "returned to a previous state of existence" in their dreams; they saw such things as sailing ships and frame-houses which no Indian had ever seen at that time. One woman dreamed of "crossing a great lake in a sailing boat", though she had never seen one in real life. A warrior who had dreamed of a particular animal would call on it in times of danger. Possessing a representation of a "dream subject" such as an animal, one could call on it any time for protection. Due to this old-time belief, the Ojibway later were reluctant to be photographed (1970:80-81, 79).

Through their dreams and vision quests, the Ojibway derived knowledge, insight, reverence "for the mystery of life which energized all things: human-kind, animal-kind, plant-kind, and the very earth itself'. This knowledge the people preserved in stories, then 
re-enacted them in rituals (Johnston 1982:vii). The Ojibway believe that many of their dreams are a gift from the Creator, though it is not always clear to the dreamer right away what a particular dream or a recurring dream symbolizes, or the message it may convey. Some of those dreams are 'healing dreams'; the dreamer eventually realizes that $\mathrm{s} / \mathrm{he}$ may have healing powers. For instance, a dream reveals a 'sacred knowledge' about curative powers of certain herbs, or of an article yet to be made, such as a woven blanket, a bag, a garment with decorations in accordance with the dream representation, a dance or a chant. Some people then became healers, medicine men or medicine women (Densmore 1970:79). How significant dreams become, and still are to the Ojibway, especially healing dreams, I learned during my interviews with Jingle Dress Dancers which shall be part of the next chapter.

The Midéwiwin

According to one oral Ojibway legend, one of many on this theme, "In the beginning", or "In the old days", Indians lived as long as 200-300 years, they "lived out the full length of life" (Johnston 1982:95; Densmore 1970:87). Then, mysteriously, they "lost the gift of health and long life"; people died after brief illnesses. The medicine men understood this misfortune to be a punishment, that a long life could only be obtained "by living a good life", and that the knowledge of healing alone was not sufficient (Johnston 1976:83). Something needed to be done. Therefore, out of necessity and the desire to increase their knowledge, the Ojibway came together to form a healing association - the Midéwiwin or Grand Medicine Society. When explaining the society, some scholars wrote about it in the past tense only, others mainly in the present tense, and some interchangeably in both tenses. Therefore, it is unclear to what extent the Midé (Grand Medicine) and its rituals are still being practiced by the Algonkins since the late 1900s. Densmore had studied the Midéwiwin over a period of 14 years during the 1950s and 60s 
with the assistance of several Ojibway informants. During those years, it appears that most of the old beliefs and rituals were still in place and taught to future candidates. A website of the Canadian Museum of Civilization (Ottawa/Gatineau) presents very brief information about the Midéwiwin, which is also unclear as to present practices. The text is mainly written in the past tense. In just one paragraph it addresses 'present-day' funeral- and memorial ceremonies. It also points out that the Midéwiwin is not specifically an Ojibway society, but is also active among such tribes as the Ottawa and Potawatomi (Canadian Museum of Civilization, n.d.).

Historically and culturally, the Midé became the Ojibways' native religion. It teaches the people simple but sound ethics, upright living, and the knowledge of healing plants. Both men and women could become members. The male member is called Midé wini ni, the female Midé wikwé (Densmore 1973:13; Johnston 1976:83-84). Receiving visions was a prerequisite for men though not for women. To become a successful and legitimate healer in Algonkian society, visionary contact with an appropriate spirit- or animal being such as a bear or thunderbird was vital (Brown, Brightman 1988: 175). Those who dreamed of water, it was said, became the most successful healers. The dream- or vision symbol (i.e. a bear) would often be portrayed in woven beadwork, a painted garment or blanket; from this, the healer would derive strength and increased healing power (Densmore 1970: 82). This link between dreams and visions, the symbols they conveyed, and the powers associated with the healer are also elements of the Jingle Dress and Dance. One major difference, however, took place -- the source of the healing was the dress and dance, and women only became the actors, the transmitters.

During the society's beginnings - as far as they are known and told -- the people's highest notion of a deity was called Mide manido or Kitche Manitou (Grand Medicine spirit). This spirit taught medicine to the Indians, especially old men, and taught them 
"how to treat the sick and to raise the dead". Yearly meetings of the Midé usually took place in the spring, when members were initiated and would renew their "spirit power" to strengthen their faith in the Midé (Densmore 1970:87; Densmore 1973:13).

Although several religious ceremonies, even mystic rites, took place during those meetings, it is remarkable that no ceremonial garments are worn or articles used, but the custom of pipe-smoking was practiced. As well, specific songs were selected, especially for the initiation ceremony (Densmore 1973:13). Midé gatherings could last for up to eight days. They would have been unthinkable without songs and dances. The rituals were numerous, long, and quite elaborate, but I shall focus here briefly on song and dance only.

The first day of the public ceremony included singing the entrance song while marching around the Medicine Lodge. Tobacco, food and medicine bags were carried along. The priest did the speaking and singing; he directed the dancing and feasting. Ceremonial objects included also water drums, gourd rattles, and birchbark scrolls with pictographs (R. and P. Ritzentaler 1970:88-90). According to Midé teachings, all songs were "revealed in the original vision and bequeathed". Those songs most closely related in origin are the Midé-, dream-, and war songs. Those connected with special medicine had the sole purpose of healing the sick; "the means of securing benefits was supernatural". The singer had full confidence in its effect (Landes 1968: 85; Densmore 1973:35). It is necessary to note that medicine (i.e. roots and herbs) and their associated songs could be sold by the owner of the songs and the medicine by the healer for a dear price (Brown, Brightman 1988: 174) (see Fig. 6).

Musical instruments used in Midé rites were very few; mainly rattles, flutes and drums, such as the water drum which was made from a hollow log and buckskin ( $R$. and P. Ritzentaler 1970:129-130). Unlike Densmore who states that neither ceremonial garments nor paraphernalia were used during the Midéwiwin, Landes mentions that 


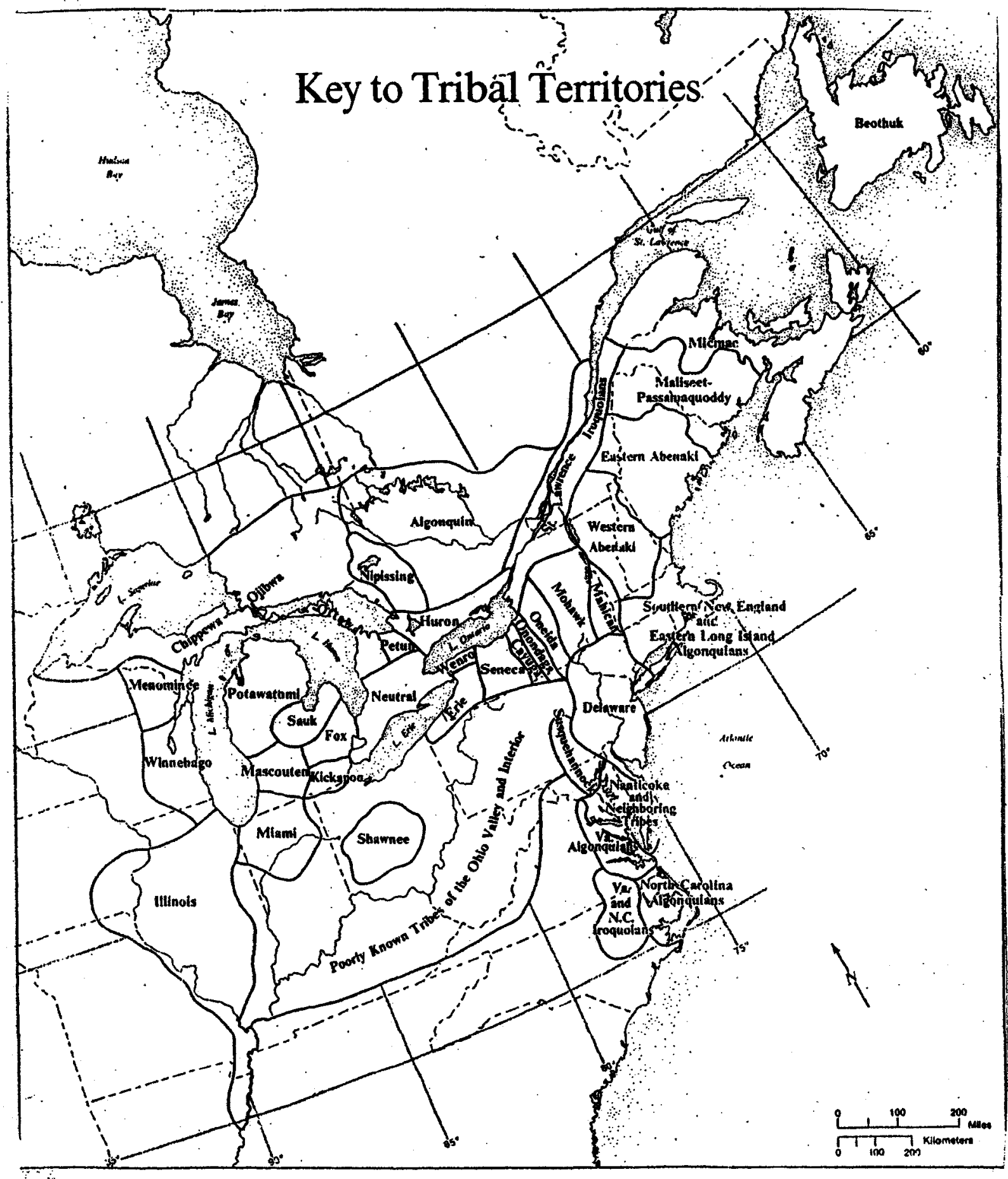

Key to Tribal Territories of the Northeastern Woodlands. W. Sturtevant, "Handbook of North-American Indians" (1979) 
clothing and medicine sacks were decorated with beadwork, even though they were crudely made. Other midé-articles were migis shells and midé dolls. Such items, which were owned individually, became more elaborate with advancing grades in the society. Some Midé members had their paraphernalia burned after death $(1968: 81,84)$.

In this chapter I have investigated the pre-historic lives of Woodland tribes, based on archaeological evidence, and concluded that religious and social rituals and ceremonies had been a vital part of their lives for centuries. In particular, rituals linked to sickness, healing and burials were of primary importance within tribal communities for men and women. This conclusion will lead me to the next chapter which will further emphasize the significance of ceremonies, especially as they were expressed in people's medicine- and healing dances, songs, and the regalia they wore. On of these ceremonies, the Jingle Dress Dance, has become a vital and permanent feature in the $20^{\text {th }}$ century. 


\section{CHAPTER III}

\section{THE JINGLE DRESS AND DANCE}

This chapter examines the historical background of the Jingle Dress Dance tradition, how it evolved into a healing dress and dance and eventually became an important feature of the powwow circuit throughout northeastern North America. By investigating the historical and archaeological data in which jingles and tinkles have been used over the centuries, their symbolic meaning on the jingle dress becomes apparent. Through my interviews with native people and observations during several powwows, the Jingle Dress Dance's relevance as a 'source of healing' for individuals, families and communities becomes very clear.

\section{History of the Tradition}

The exact or even approximate time of the Jingle Dress Dance's origin is still unknown and may remain so in the future. Many stories exist as to how, where, and when it all began, notably those of the Ojibway people and Maggie White. When interviewing aboriginal people, I learned that the precise time and place and its origin is less important than the Jingle tradition's symbolic aspect, especially its healing powers. All stories are accepted by the people, regardless of nation or tribe. As Miller explains, to the Anishnaabeg, the western linear perception of tradition "as deriving from a single point of time and passed down through successive ages" does not pertain to their cyclical concept of time (1995:9). One can deduce that, to the aboriginal women themselves, the exact time and place of the Jingle Dress Dance is less relevant than the fact that they were able to recover some of their past traditions many generations after they had almost been lost. One of the processes through which such recoveries occurred was through the medium of dreams. This may have been the case with the Jingle Dress and Dance. 
In conducting and analyzing the research for this thesis, though, a chronological account of the Jingle tradition's history, as far as it can be determined, has been applied.

When did the Jingle Dress Dance narrative actually begin? One member of the Ho-Chunk Nation of Wisconsin announced during a Summer Ceremonial in 1995 that he dates the jingle dress close to the 1600 s. He placed it "within the historic framework of the Anishnaabeg migration from the East, at a time when the Anishnaabeg Confederacy was dying, especially its carriers of tradition. The Ho-Chunk, however, were nearly destroyed by epidemics during the 1630 s. They keenly pointed out to the other, more recent arrivals of tribes to Wisconsin "the antiquity of their traditions", and that the HoChunk arrived first, bringing the Jingle Dress legend with them (Browner 2002:55-56). However, in his narrative, he was not able to back up his origin account with any 'facts' or a more detailed oral description.

The only reliable factor of the Jingle Dress history is that it is based on a legend of many variations, and the legends in turn are based on somebody's dream. These elements of its origin have been told and eventually written down throughout the $20^{\text {th }}$ century. As Walker mentions, the many legends about the Jingle Dress "are all accepted as 'a story", not only by the Ojibway, but also by other tribes in their regions, such as the Dakota (2001:5).

Another version of an oral narrative, as referred to by Miller (1995) is that of the Mille Lacs origin tale. This story emphasized "the giving of the dress to the people", but omitted the jingle dresses healing properties. The legend conveyed to her by an Ojibway jingle dancer from North Dakota was that of a holy man on the Mille Lacs Reservation (Minnesota). He dreamed of four women appearing in jingle dresses, telling him how to make them, and the songs to go with them. After awakening, the man's wife made four dresses with metal jingles on them. Four women presented them at a dance with the 
accompanying songs. This apparently took place in 1919 and soon the jingle dress dance spread through Ojibway territories. According to Miller, this tale is supported by "strong photographic evidence". Yet, her thesis does not include any photographs of that time (only from 1932 to 1961), but she remarks that the jingle dress dance tradition in Minnesota continued from 1932 to the present (1995:54-55).

Whether through searching the available literature or learning from interviews with native Indians, any knowledge about the jingle dress' origin is incomplete, fragmentary. Miller, in her interviews with Anishnaabeg, tells of their believe that the jingle dress predates European contact, that those early dresses were adorned with jingles made from shells, deer toes, and small animal bones. They may or may not have had spiritual powers attributed to them at that time. Therefore, the modern Jingle Dance Dress could be "an innovation of an older, perhaps dormant tradition" (1995:12).

My own, somewhat limited information from oral informants, revealed that Aboriginals were certain that the jingle dress and dance were either $75-100$ years old, or that it originated in pre-contact times. However, everyone was aware of Maggie White's influence in popularizing the jingle dress, beginning in the mid-20th century, after which it spread over most of North America, especially on the powwow circuit. It is generally known among native women and jingle dancers that deer hooves and animal bones were once used before metal cones became the 'standard' jingles for their dresses.

The Library and Public Archives Canada (in Ottawa) and the literature disclosed several early photographs from the years 1905,1930 , and early 1930s (See Figs. 8-12). Girls and young women clearly wore jingle dresses, but there was no mention of them dancing in those dresses. The 1933 photograph describes the girl as preparing "for her role in Mrs. Wilson's mystic Star Dance". From this very scant photographic collection, one may deduce that, throughout the 1800 s and up to the $1930 \mathrm{~s}$, native females wore 
jingle dresses on festive occasions only and were likely not aware of the dresses' origin and symbolic significance. The fact that those early dresses were decorated with a great number of jingles which may have been fashioned from tin lids, indicates at least a nonreligious or temporal meaning assigned to them. Jingles and tinkles have been used for decorative purposes by aboriginal peoples, women and men, for many centuries. The next section will examine some of their origins and uses and may shed some light on the jingle dress in general. (See Fig. 13)

Before I move on to the important role Maggie White played in popularizing the Jingle Dress Dance, the seminal version of the jingle legend needs to be told. A Chief's young daughter was very ill and gave no sign of recovery. During her illness, her father had a dream in which he was instructed by a woman to make a dress with numerous metallic jingles stitched on it. To dance in this dress would heal his daughter. Next day, the Chief instructed some women to make four dresses, each one in the four sacred colours - red, yellow, white, blue - with four rows of jingles rolled from snuff cans stitched on them. One dress was put on the sick girl, the other women in the jingle dresses danced around her, using prescribed steps. While the women danced and said prayers to dispel the disease, the jingles made bell-like sounds. After the third day of jingle dress dancing, the Chief's daughter was miraculously cured (Browner 2002:54). Although it can be presumed from this narrative that the jingle dress was soon regarded as having healing powers, other versions of the legend did not address any specific or sacred powers to it. An instrumental, even historic transformation, however, occurred in the 1930s through Maggie White, an Ojibway.

Maggie White, who died in 1991, was an Anishnaabe-Ojibway from Whitefish Bay, Lake of the Woods, Ontario. Cary Miller who (during her thesis research), was given access to a taped interview with Maggie White a few years before her death, conveyed the 


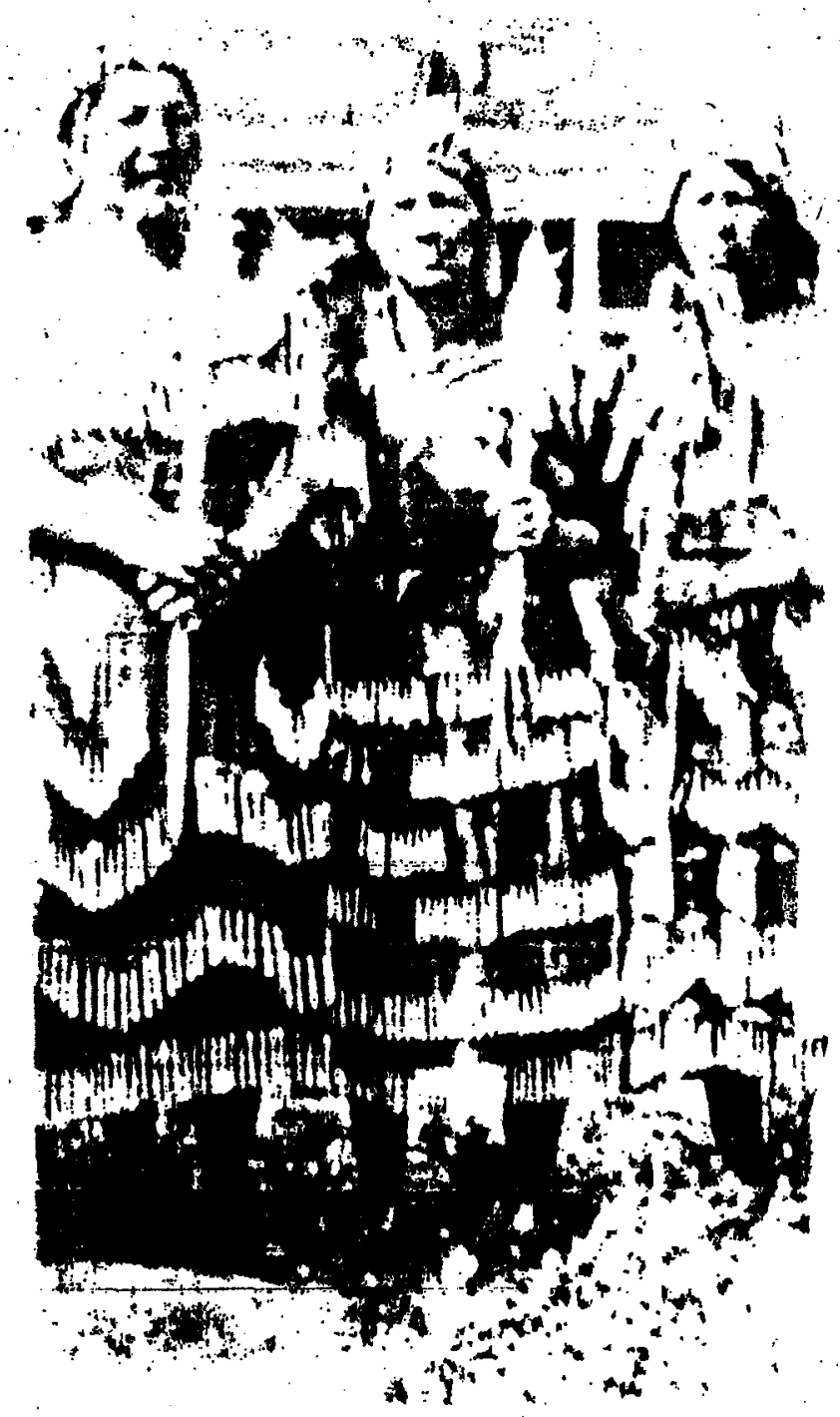

Ojibway: women from Lake of the woods, Rat Portage, Kenora, Ontario, ca. 1905; Lake of the Woods Museum, Kenora, Ontario. 


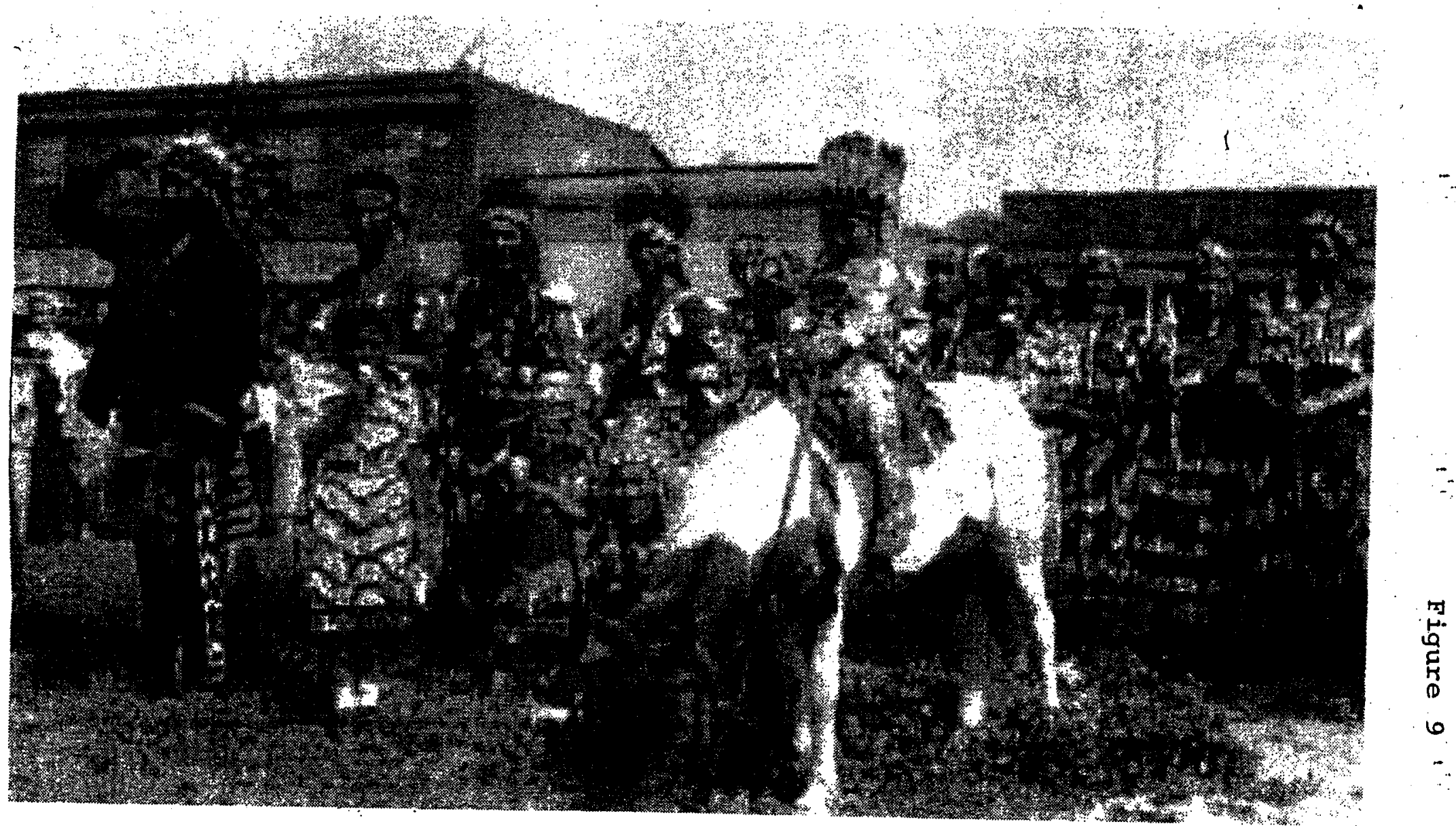

Oj1bway women from lake of the woods.region, Ontario, ca. 1905; courtesy of Lake of the Woods Museum, Kenora, Ontario. 
Figure $10^{\prime} \quad 58$

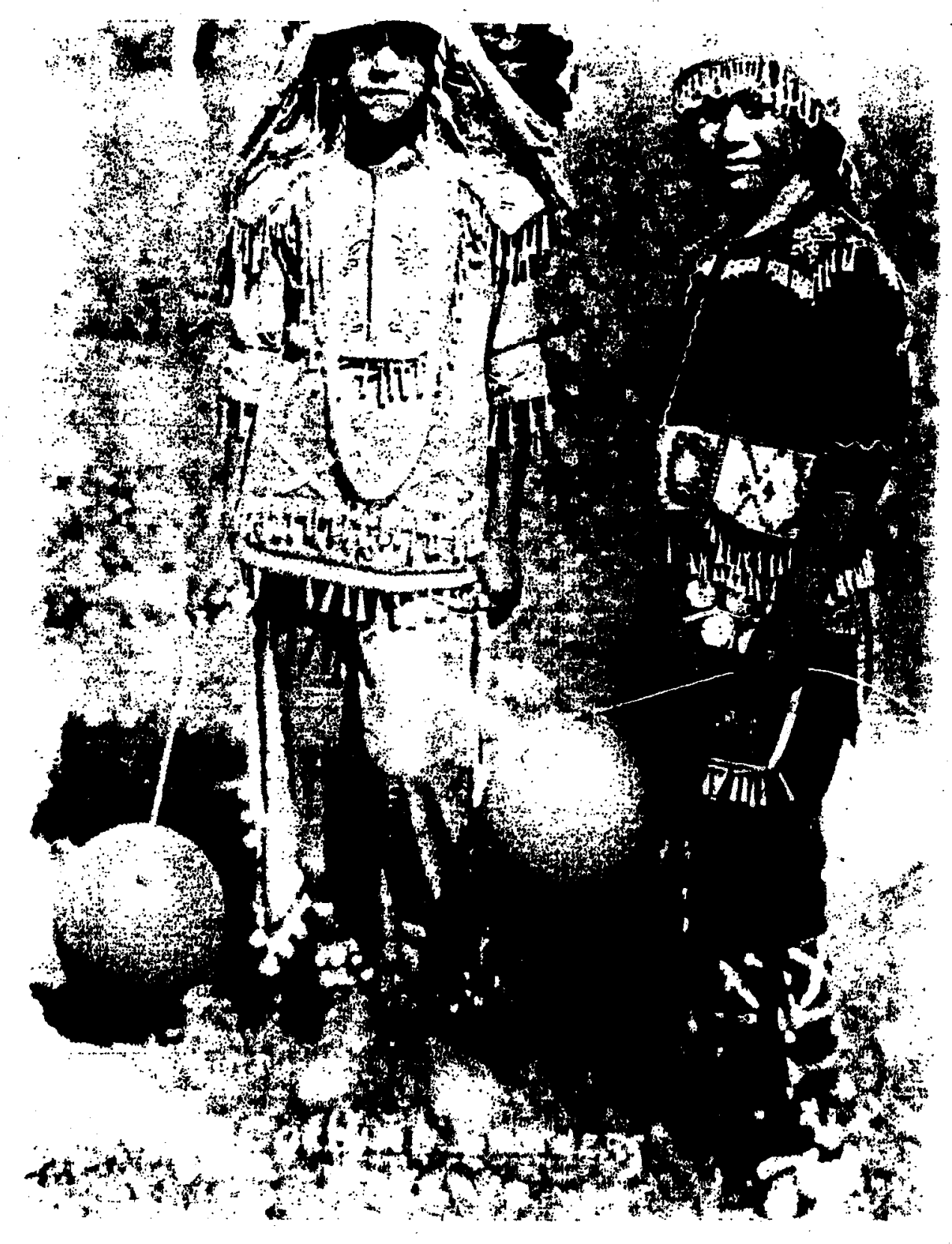

Jingles on Male Powwow Dress

Postcard photograph (1930s); "The Corbine Brothers, Reserve, Wis."

Placement of jingles on shirts is similar to the placement on jingle dresses. This style does not appear after the 1930s. Jingles may have been associated with female dress." Roberts, Chris, Powwow Country - People of the Circle (1998). 
Figure 11

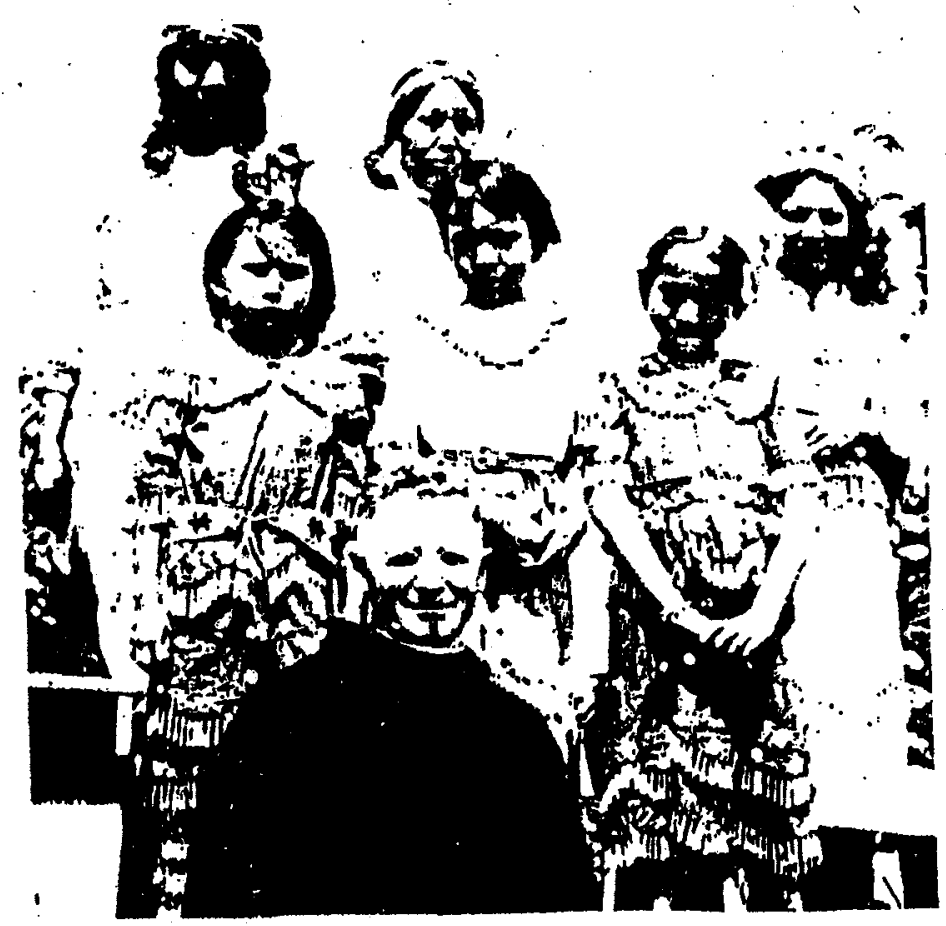

Missionary with Dakota Sioux Girls from

St. Michaels Mission, North Dakota, ca. 1930 wearing Jingle Dresses.

Reproduced from "Whispering wind", Vol. 24, No.2, Summer 1991. 


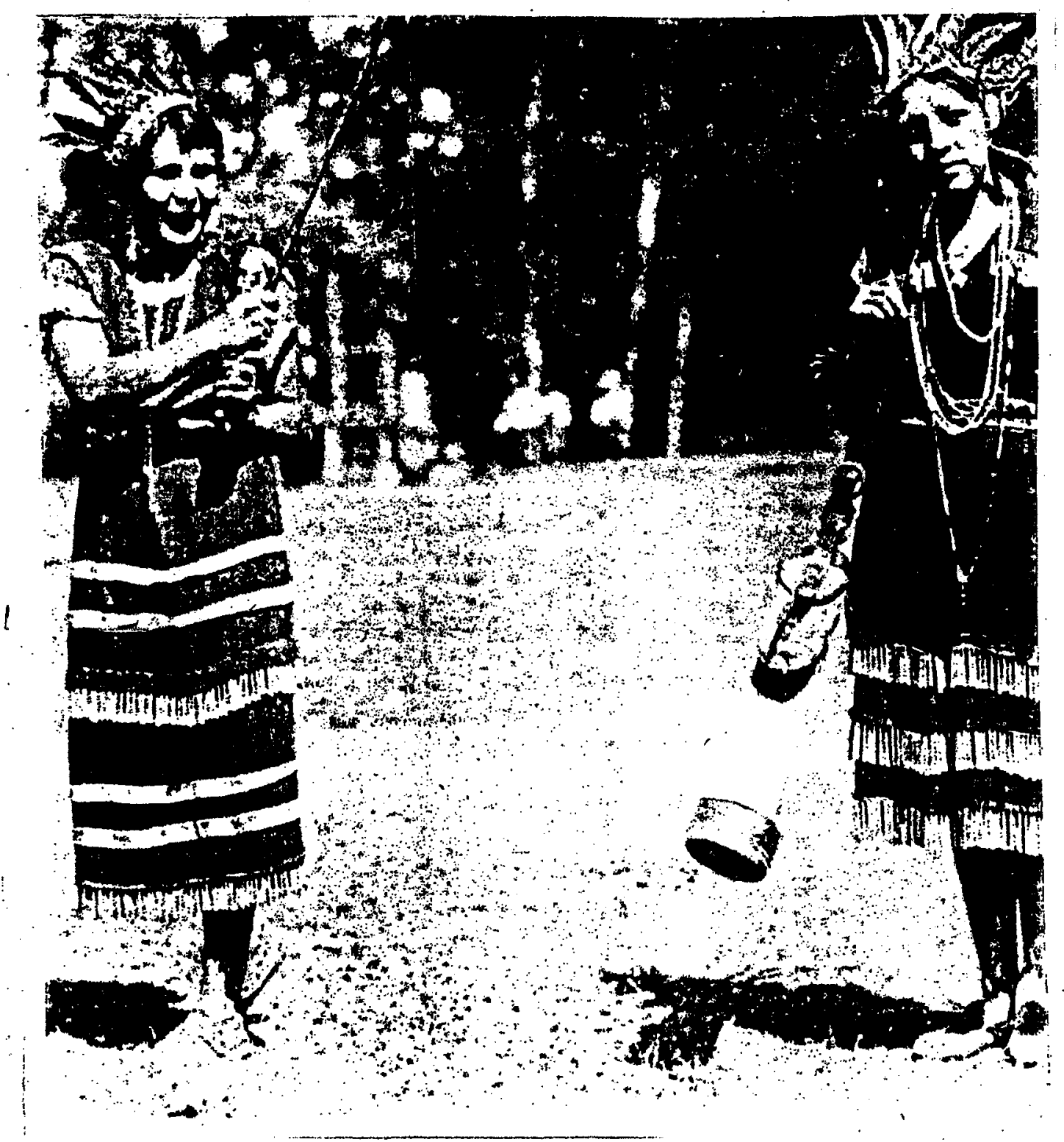

Chippewa Maidens: on Itasca state Golf: Courser July 1.932

These are two different types ofjingle dresses, one with a minimal amount of jingles (two rows), one with twice the amount of jingles. The jingles appear longer than current ones. Photograph from the Minnesota Historical Society, Saint Paul, MN. 
Figure 13

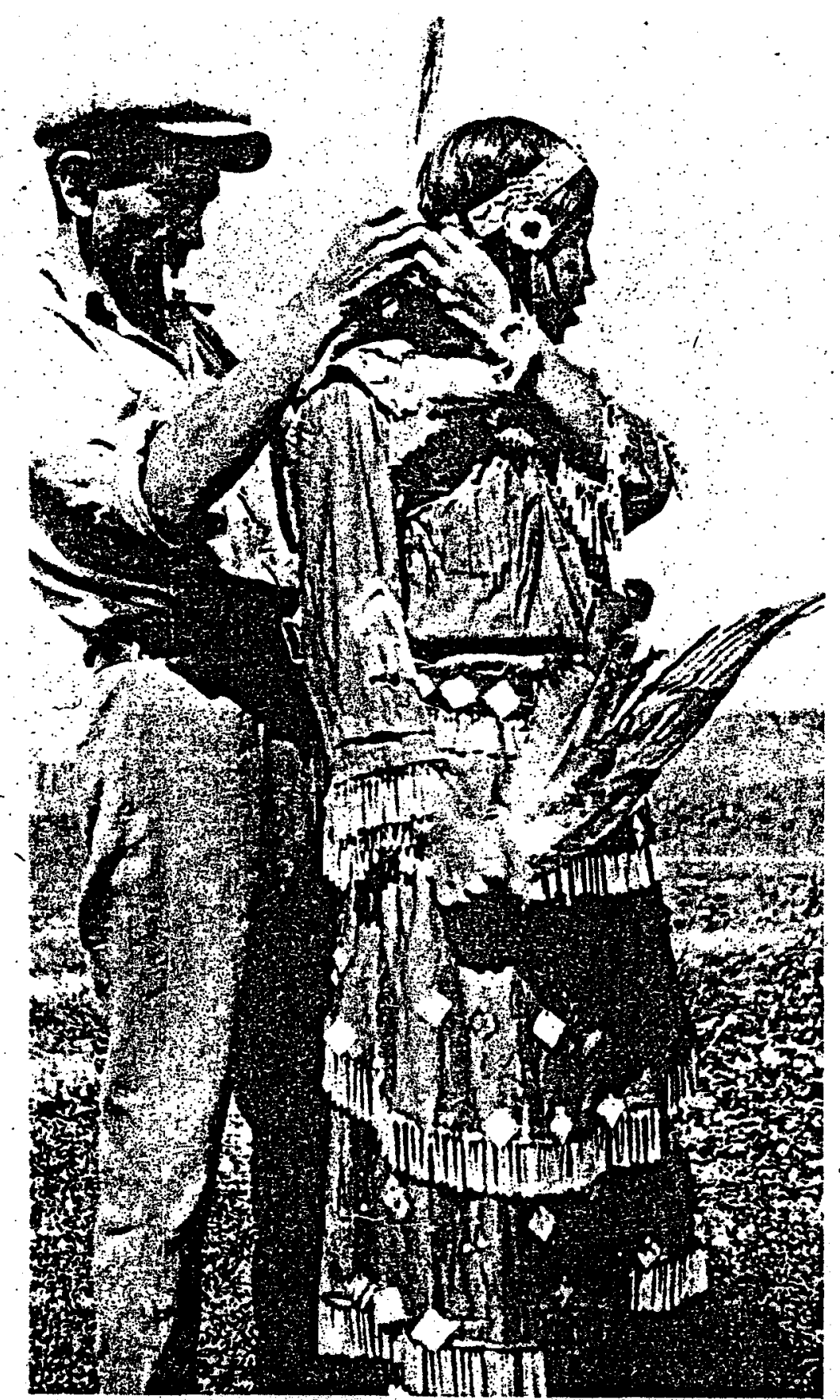

$\therefore \quad$ The son and daughter of Mrs. Maggie Wilson. Leonard Wilson is helping his sister janet adjust the eagle feather completing the regalia for her role in .Mrs. Wilson's mystic Star Dance. Photograph by Ruth Landes, 1933.

Landes, Ruth, "Ojibwa Religion and the Midewiwin", Madison: University of Wisconsin Press, ( 1968$)$. 
following story of the jingle dresses' origin:

Maggie was a sickly child. At the age of eight, she dreamed about a particular dress with jingles on it. Her grandfather interpreted her dream to mean that she should wear such a dress and dance in it to the beat of his drum. She then would surely get well. The dress would be her medicine. Maggie danced in this jingle dress for the first time in a lodge used by the Midéwiwin society. The more she danced in this dress, the healthier she felt. The jingles on her dress at that time were made from cowry shells, also called megis shells; they "figure prominently" in the Anishnaabe Midéwiwin society (1995:57).

Miller further explained the symbolism of the megis shells such that they were "shot" into the initiate of the society "who then falls down as if dead, and subsequently revives by regurgitating the shell". This "shooting of the shell" indicated to the patron spirits "to send their mystic charge of life into the patient". As in other versions, it is again possible that Maggie's dream, and her grandfather's interpretation of it, may be a resurgence of an older tradition (1995:57-59).

When Maggie White, her daughter and two daughters-in-law first danced during a powwow in Minneapolis in 1968, then at exhibitions from 1977 to 1982 , the Jingle Dress Dance was still not a category at powwows. Nevertheless, it eventually became popular throughout Ontario, Manitoba, Saskatchewan, Alberta, and British Columbia, and then expanded across the border into South Carolina, Florida, Texas, Oklahoma, Arizona, and several other US-states. Maggie and the other three girls became the centre of the Jingle Dress Dance Society (Walker 2001:9-10; Browner 2002:54).

In summary, one can determine that the jingle dress has existed for some time, possibly throughout the 1800 s. However, the dancing steps and the songs appear to have become a 'true story' rather than a legend through Maggie White. It therefore had its 
proper beginnings as an aboriginal female tradition in the 1930s, and as an exhibition and powwow category in the 1970s. It became widespread and popular over most of North America right into the $21^{\text {st }}$ century.

I will address the Jingle Dress Dance's and Maggie White's link to the powwow more closely in the next chapter.

\section{Jingles and Tinkles - What do they mean?}

The idea of garments and other objects decorated with tinkles and jingles, especially those envisioned in dreams, needs to have a source, a beginning in time and place. Since metal jingles on the jingle dress are of utmost significance, it is expedient to examine how they developed over the centuries in the practice and expression of native peoples in North America.

My research revealed that the production of metal ornaments (as well as tools and weapons), in particular those made of copper, already existed in North America during the Archaic Period (5 000 - $1000 \mathrm{BC}$ ), drifting from the west into southern and eastern Canada, including Ontario (Wright 1972:23). According to Willey, copper was never melted or cast during the Old Copper Culture (Middle Archaic Period), but was "worked by cold- and hot-hammering techniques. It was an independent invention of the people in the Great Lakes region where copper ear-ornaments had been discovered in burial mounds of the Hopewell culture during the early Archaic and Woodland Periods (1966:261, 282). In contrast to Willey, however, the article Crucibles for Casting Found at Cahokia? (anon. [a], n.d.) points out Neiburger's discovery of scientific evidence that prehistoric Indians melted and cast copper, based on findings from a $1000 \mathrm{BC}$ site in Menominee County, Michigan. To determine how extensive the use of melted metal was during the Archaic Period would necessitate some extensive testing and evaluating of the 
25,000 existing copper artifacts in the US. Although Neiburger is an amateur metallurgist, his findings have been supported by professional metallurgists. In Wright's opinion, the functions of the native copper and stone objects, including bossed bracelets and disk pendants, found in Late Shield Archaic graves (1 $500 \mathrm{BC}$ ) were not known, yet he admits that suggested religious ideas in reference to such ornaments seemed to have originated in mid-western states and then been introduced into northern areas (1972:20).

One example is the site of the Hopewell Mound along the Scioto River (Ohio) from $200 \mathrm{BC}$ to $500 \mathrm{AD}$, from which numerous ancient copper ornaments had been excavated, a site first explored in 1846 . Necklaces and beads, formed of narrow metal strips, earrings and engraved sheets of silver date to as early as $5000 \mathrm{BC}$, while other ornaments which were sewn into clothing, date from $200 \mathrm{BC}$ to $400 \mathrm{AD}$ (anon.[b], n.d.). Again, one has to deduce that certain of the metal ornaments sewn into garments were of the type of jingles or tinkles, possibly worn by shamans or healers. Dubin mentions thousands of artifacts of river pearls, bone pins, and tortoise-shell rattles which would have adorned garments made from animal skin. They were found in Kentucky and date to about 3000 BC. Great Lakes artisans (2 $500 \mathrm{BC}$ ), who were the earliest American metalworkers, "cold-hammered copper nuggets into thin, flat sheets", then rolled them into tubular beads or cut them into pendants (1999:153).

Trading occurred to a great extent in the Lake Superior area in raw materials as much as in stone- and copper ornaments such as beads, as early as $3000 \mathrm{BC}$. Some of the richness of the jewelry and regalia of eastern Woodland traditions can be derived from contemporary native art like Mississippian etchings, and from Archaic effigy figures and petroglyphs. The findings in Adena and Hopewell burial mounds suggest that a social hierarchy already existed in which the importance of grave goods signified either a belief in an after-death existence, a journey through the underworld, or as an attribution of 
special honours to a social elite. Such regalia and jewelry of deceased members of the elite as depicted on Mississippian engravings, consisted of beaded bands attached to wrists, elbows, knees and ankles. That ornaments were positioned at particular "vulnerable body points", signifies them as articles of social status and as protective charms (Dubin 1999:29, 153, 159).

Among the Dumaw Creek Indians of the Late Woodland Period, it was customary to adorn the hair, which was often coloured with red ochre, with as many as 60 tubular jingles made from shining copper. These "tubes or hair pipes were held in position by tresses of hair that had been inserted through the tubes and tied in a knot larger than the opening of any given hair pipe" (Quimby 1966:29). A skull of a Creek Indian (from approx. $1600 \mathrm{AD}$ ) was discovered with copper jingles still tied to his hair (see Fig. 15). Other similar ornaments among the Creek were wooden earrings, covered with hammered copper, tinkling cones of sheet copper, and copper finger rings and bracelets. An unusual object was a bird, carved of a piece of antler, with copper tinkling cones fastened to the bird's tail (1966:39).

Although clothing made from natural products such as animal hides and plant fibres did not survive in the soil of the burial mounds and other grave sites, the tradition of producing such clothes was still much prevalent at the time of first contact with Europeans. Only when European traders, missionaries, members of the French and British military, and others, increased the contact with Indians, did changes in clothing material and ornamentation occur. Quimby remarks that old types of artifacts were then modified by the substitution of imported material and the introduction of new techniques and tools. Such articles included cloth woven from imported yarns, ornaments from imported silver, tinkling cones, tubular beads, and hair pipes made of "brass kettle fragments" instead of native copper. Overall, Indians then used a combination of native and imported materials, 
as well as native and European techniques for the manufacture of articles (1966:10).

What appears certain is the widespread use of ornamentations that included metal, shells, deer hooves, birds' claws, etc., as jingles and tinkles among North American natives in prehistoric times and well into the $19^{\text {th }}$ and $20^{\text {th }}$ centuries. They appeared on a $19^{\text {th }}$ century Pueblo dance kilt made of buffalo hide and trimmed with tin cones (Berman $1997: 125)$, and they were used on some $19^{\text {th }}$ and $20^{\text {th }}$ century jingle dance dresses. Throughout the literature, there are descriptions and photographic representations of North American native garments and other objects, decorated with jingles, tinkles, and bells. For instance:

a) A Sarsi war-charm necklace with silver bells; a Cree medicine necklace of buckskin with tin cones;

b) A young Apache girl's buckskin dress with tin tinklers and abalone shells to be worn at a puberty ceremony which is still performed today;

c) An Apache cloth doll in deerskin dress (made about 1855-1860) with three rows of tin tinklers (Dubin 1999:247, 512).

a) An embroidered leather bag with brass tinkling cones from the Great Lakes region (Quimby 1966:73), and a Chippewa buckskin pouch with metal cones (Ewing 1982:237) (see Figs. 16, 17).

a) A young Dene (Slavey community) girl's smoked-hide dress with glass beads and cut-out pieces of tin (late $1800 \mathrm{~s}$ ), to be worn during a drum dance after a period of puberty seclusion;

b) A Slavey type woman's belt (late $19^{\text {th }}$ century) of caribou hide, with bird bones and pieces of tin (Thompson 1994: 81, 85, 86).

a) A male dancer's skirt with long metal-cone tinkles attached at the bottom (Heth ed. 1993:82). (see Fig. 19) 
Figure 15
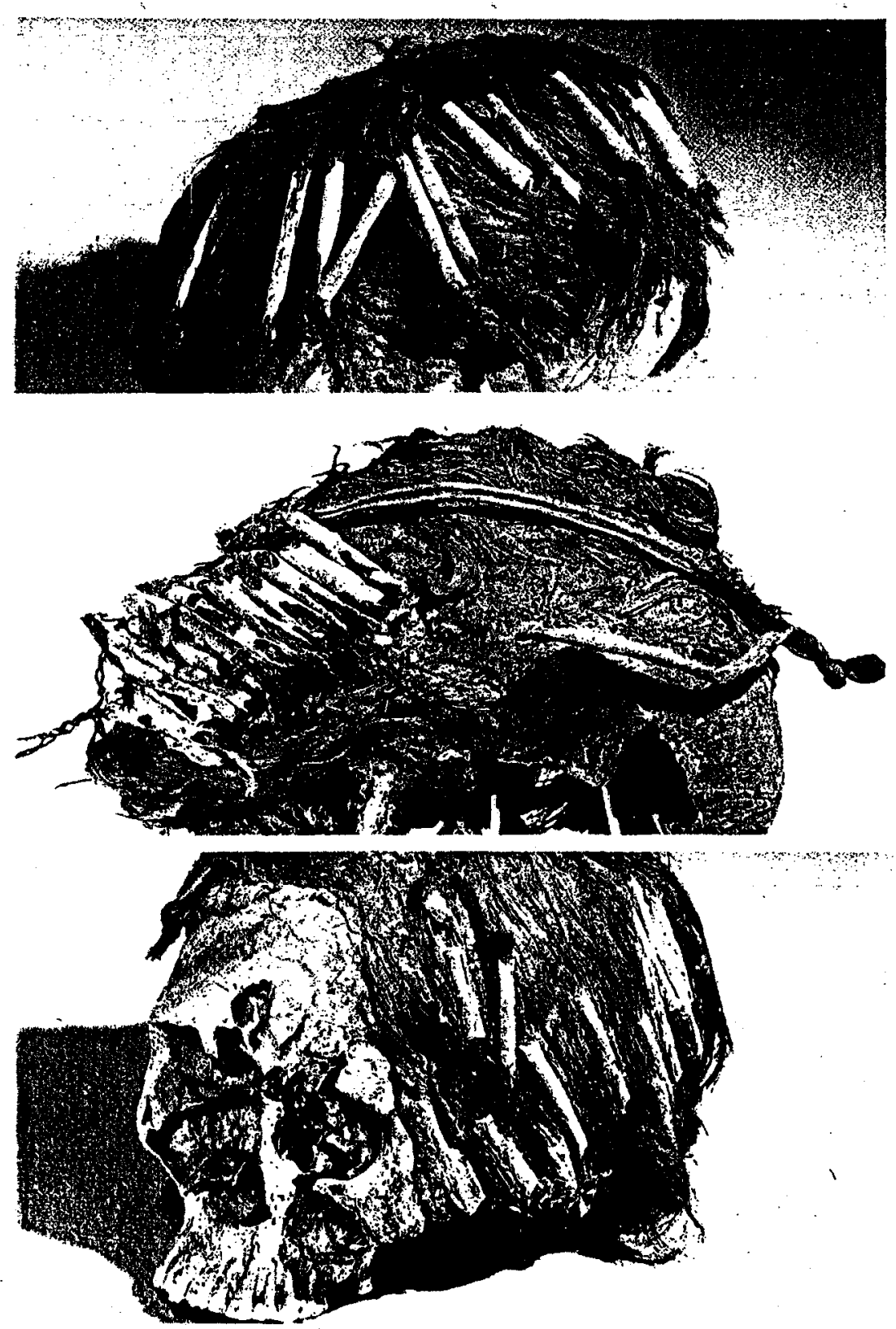

Copper hair ornaments in original position on skulls of Dumaw Creek Indians. Archaeological specimens of about 1600. Courtesy of Chicago Natural History Museum. Quimby, G.I., "Indian Culture and Trade Goods" (1966) 
a) An Ojibwe dance sash with copper cones

b) An Ojibwe drum with jingles (Diamond et al 1994:115) (Figs. 18a, 18b)

Though not a Woodland but a Plateau tribe, the Nez Perce women had developed a style of dress in the early 1800 s which was decorated with tube beads, cowrie and olivella shells, elk-teeth dangles, and brass thimble dangles. These were attached either to the yoke or the back of the dress (Kearney 1994:8-9). Koch points out that Plains Indians who traded in various types of metals with Eastern Woodland tribes already in the time before Jacques Cartier (1535), used a "pounding, cutting, and filing" technique to produce sheet metal. It was then cut, smoothed down, finished and polished, before being fashioned into ornaments, which included tinklers. These cone-shaped tinklers were attached to most kinds of garments, pipe bags and pouches. They were still commonly used throughout the 1800s, up until the early 1900s (1977:71-72). Among the Dene (North-West Territory), Thompson writes, when bones, beads and metal cones were attached to dresses and belts in the mid-to late 1800 s, they functioned as "a musical accompaniment" when the wearer moved. "Her dress sounded like bells ringing when she was dancing". It had pieces of steel and all kinds of different things on it (1994:85). It is therefore not fully correct when Walker (in her MA-thesis) first states that the Ojibway may have produced copper tin cones by themselves, but then indicates that the tin tobacco lids were possibly introduced during the early fur trade (1640-1700), and lastly claims that the tin cones were already manufactured when introduced by Europeans to the Ojibway, and "thus became replacements, not innovations" (2001:28). It is correct, however, that snuff tin lids replaced copper in many, though not all instances (and only gradually), as a metal for regalia decorations, especially on garments such as the jingle 


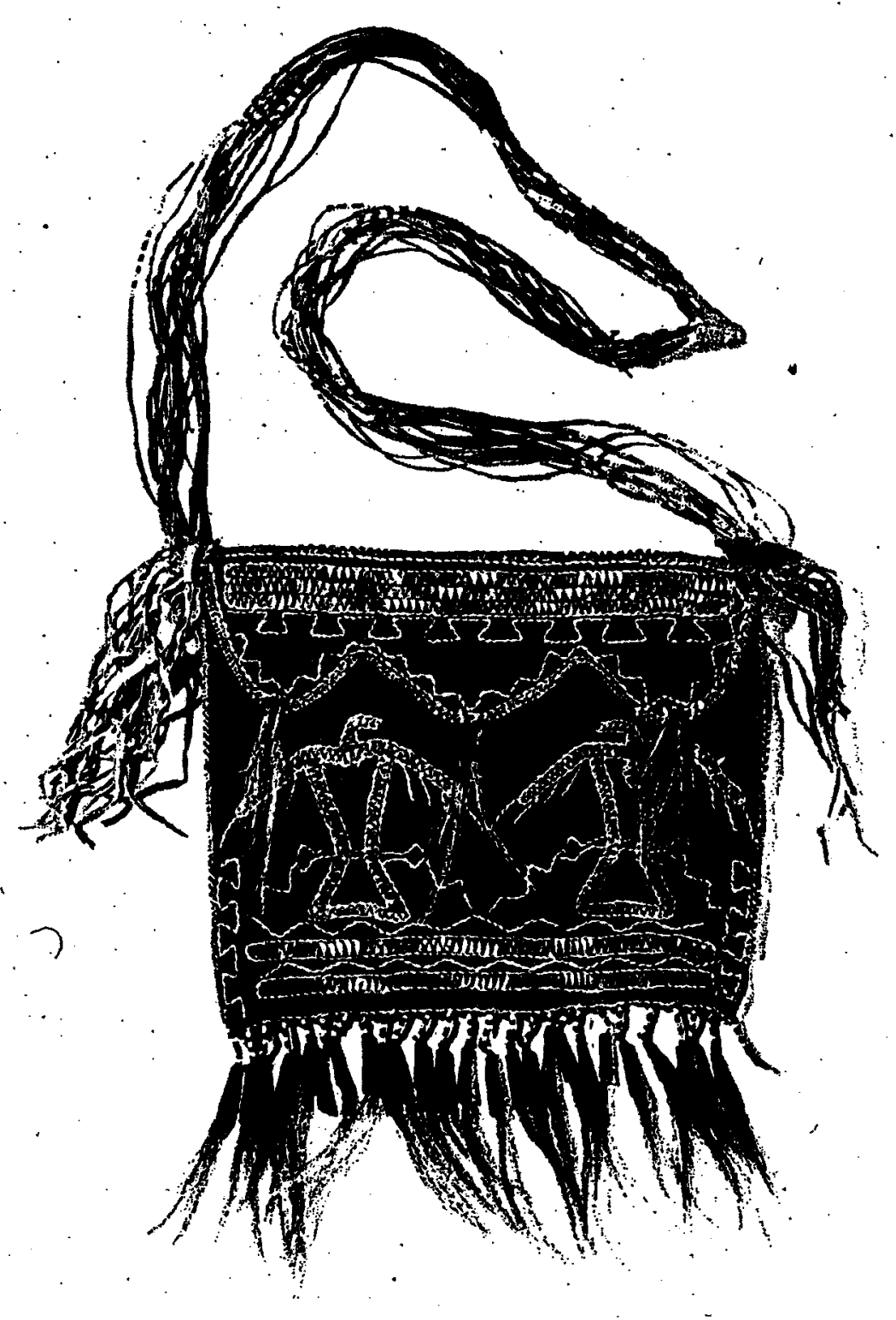

Brass tinkling cones attached to a leather bag, Chicago Natural History Museum, acquired by Jeffrey Amherst between 1758 and 1763.

Quimby, G.I., "Indian Culture and European Trade Goods": (1.966). 


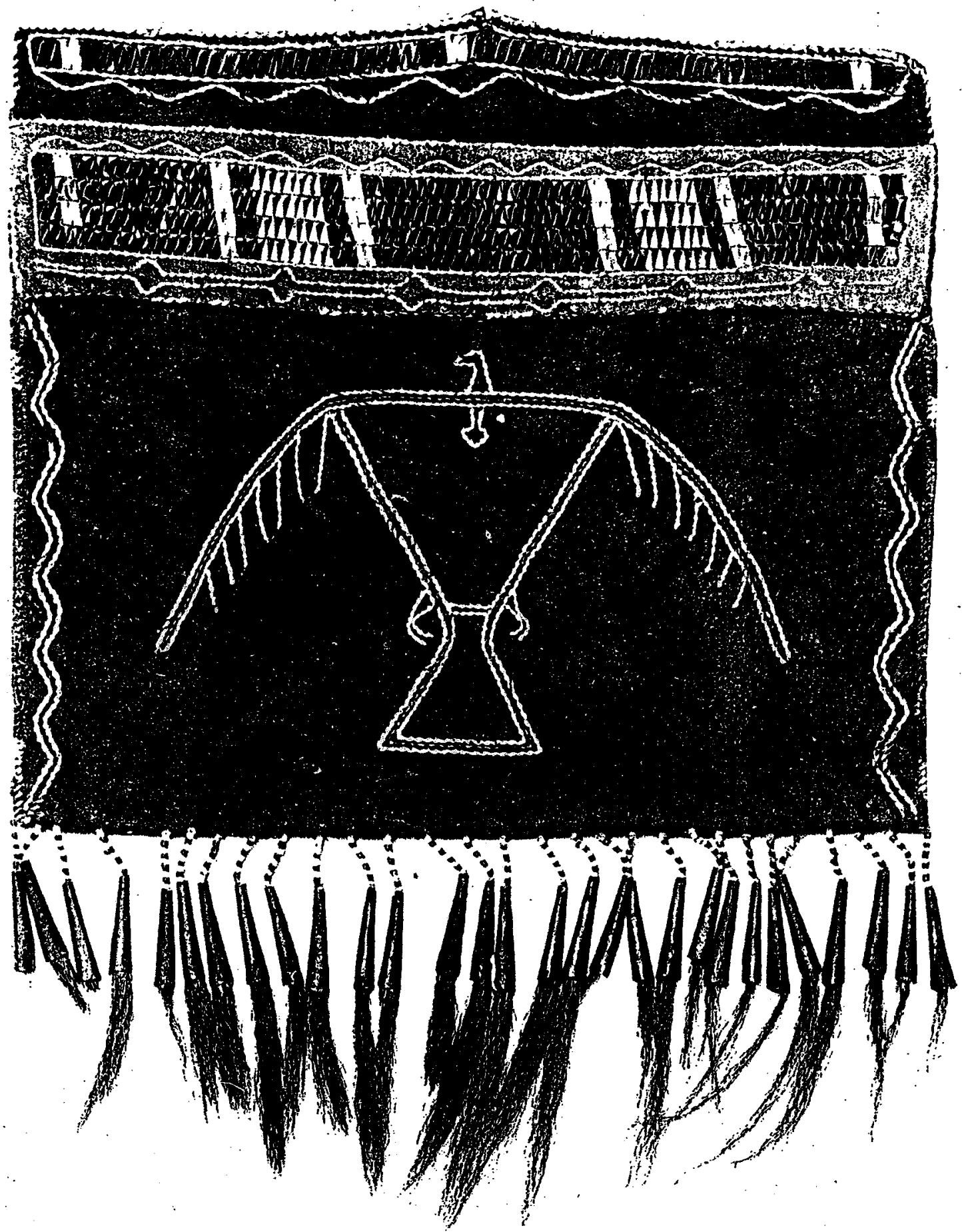

Pouch with metal cones, Eastern Woodlands (Chippewa), ca. 1780 .

Ewing, D.C., "Pleasing the Spirit" (1982), New York: Ghylen Press. 


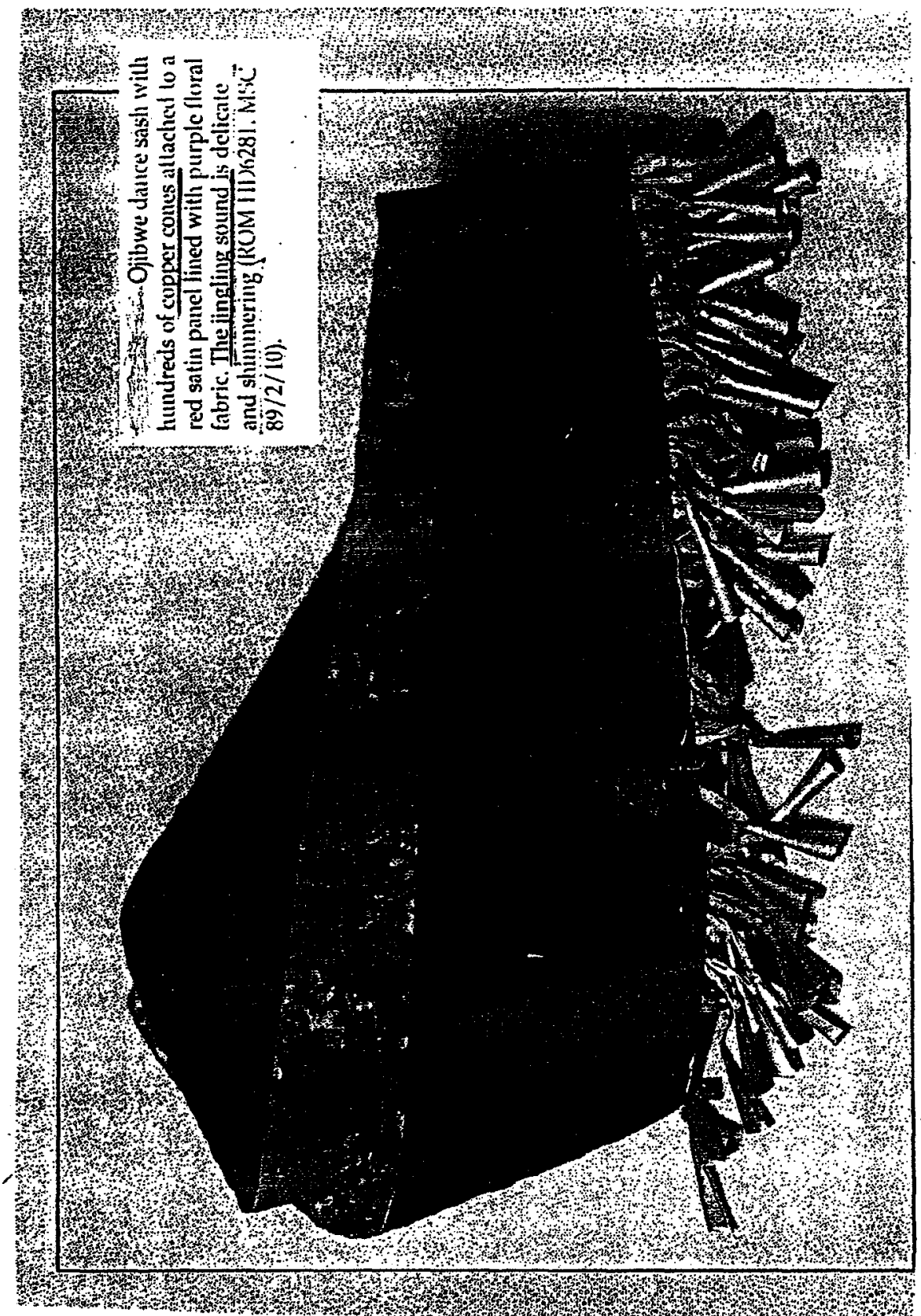

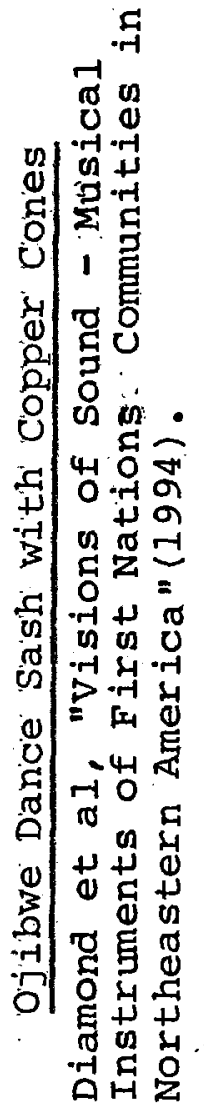




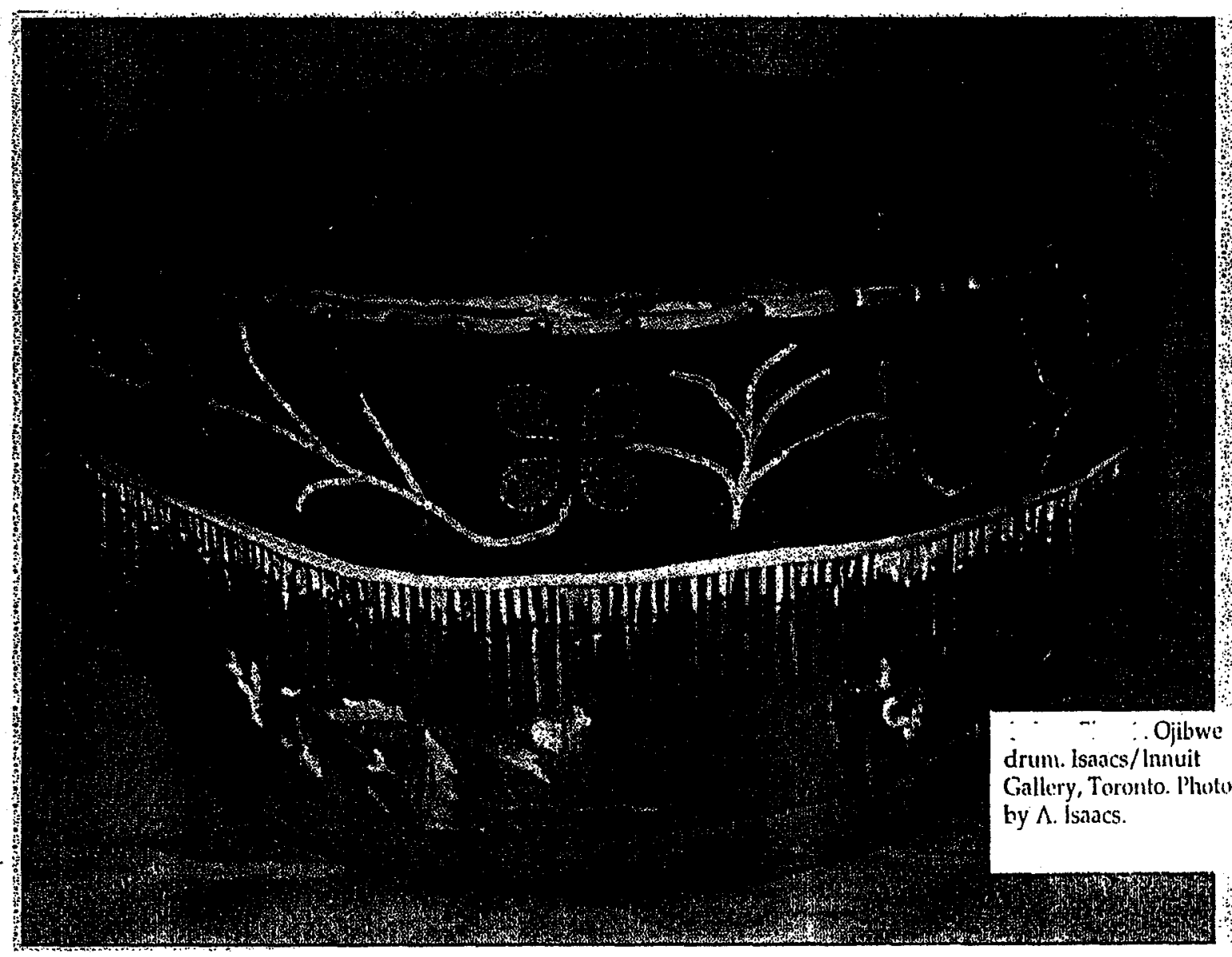

$-$

\section{Ojibway Drum with Jingles}

Diamond et al, "Visions of Sound - Musical Instruments of First Nations Communities in Northeastern America" (1994). 
dress. For instance, copper cones were still used and preferred in the early $20^{\text {th }}$ century to produce rattles and to decorate drums, especially by the Ojibway. Only when copper was unavailable, were jingle cones produced from tin. The ringing and jingling sounds created by copper were associated with women (Diamond et al 1994:87, 115) (see Fig. 19). The author did not explain this link, but pointed out that these sounds were particularly important for women's rattles.

What do some of the museums and the National Archives reveal or exhibit about jingles and tinkles as traditional North American aboriginal ornamentation? My extensive research at Library and Archives Canada (Ottawa) resulted in only one photograph, depicting two Sarsee Indian girls (Ernest Brown collection; n.d., possibly late 1800s). Their woolen dresses have metal cones attached to fringes at the centre and bottom of the skirts. In the absence of any explanation one may guess that this regalia was worn on festive occasions, but has no similarity to jingle dance dresses. It is also doubtful that the girls danced in those dresses.

I had extensive access to the Canadian Museum of Civilization (Ottawa-Gatineau) and its library, although a visit to the museum's vast collection of artifacts (in storage) did not materialize. However, the area of the museum called 'The Dig', exhibits a cape or skirt made of animal hide to which five rows of tinkles are attached. These tinkles were produced of such natural materials as birds' beaks (possibly puffins) and hollow claws. An explanation of this artifact was missing. In 'The Den' of the museum are two dioramas, one of a shaman whose apron has numerous jingles attached which may also be of puffins' beaks. The other diorama depicts a Chief, wearing a similar outfit. Both shaman and chief were probably from the North Pacific Coast. Despite intensive communication with museum curators and ethnographers, as well as electronic searches, I was unable to receive any detailed information on those exhibits. 
Figure 19

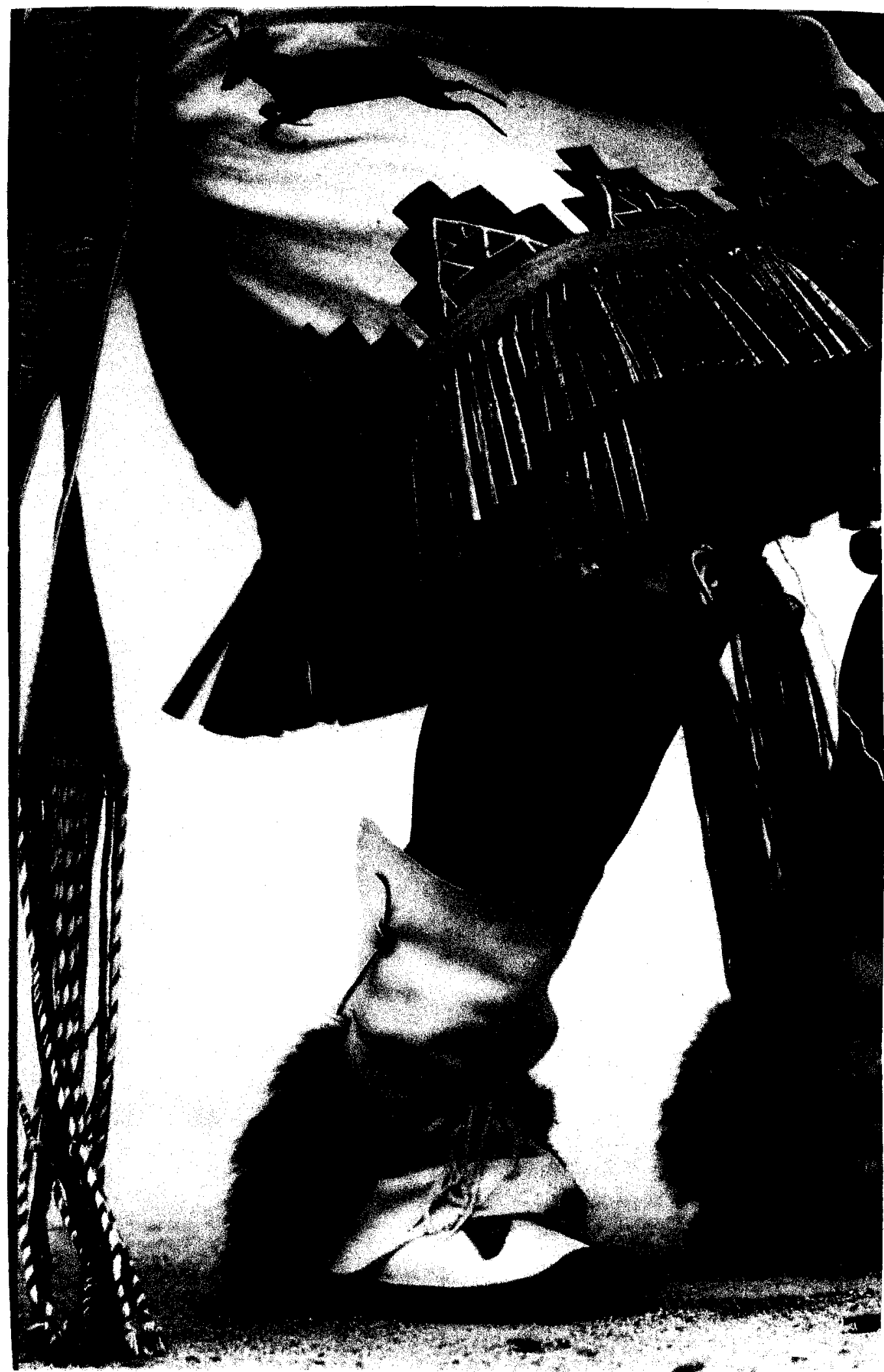

Male Dancer's Skirt with Metal-Cone Tinkles

Heth, $C$. "Native American Dance:Ceremonies and Social Traditions" (1982) 
During a visit to the Royal Ontario Museum (ROM) in Toronto, I came across two artifacts of shamans' paraphernalia to which metal jingles were attached. An electronic search did not reveal more information.

One vital question about jingles and tinkles remains to be answered: What is the meaning of these types of ornamentation or decoration? What do they symbolize, and what is their spiritual or religious significance? Archaeological artifacts of the Late Archaic-Early Woodland and Old Copper cultures in northern New England and eastern Canada discovered in burial sites "point to an elaborate ritual system, involving lavish burial practices" (Trigger 1978:39). Copper adzes, shell gorgets, shell beads, etc., were buried with the dead, but it cannot be ascertained with any certainty whether these ritual practices were of a religious or secular nature only. Trigger mentions that the burial sites, consisting of mainly cemeteries, give little indication of the "actual lifeway" of the people of that period. He merely suggests that "a basic case of religious belief" may have existed $(1978: 39,41)$. Wright, however, states with certainty that the burial practices, especially the construction of mounds, which began about 2000 years ago, were associated with religion. About $\mathrm{AD} \mathrm{400,} \mathrm{there} \mathrm{was} \mathrm{a} \mathrm{"breakdown} \mathrm{in} \mathrm{the} \mathrm{ritualistic} \mathrm{treatment} \mathrm{of} \mathrm{the} \mathrm{dead"}$ and ceremonialism of the Hopewell culture declined $(1972: 49,51)$. Yet, he does not elaborate or provide further information about the religion and its ceremonialism. It is also worth mentioning that the 5000-year old Copper Culture sites of Oconto and Oscola (both in Wisconsin, USA) unearthed such artifacts as "pieces of spiral-coiled tubing" which may have been used as ornaments like tinklers. However, at both sites, utilitarian objects were far more numerous than ornamental cones (Baldueck, n.d.).

It certainly appears plausible that religion and its rituals played a role in the lives of the Eastern Woodland people and that discovered artifacts such as bells and tinklers possessed symbolic values. Likewise, it can be assumed that the widespread use of those 
ornaments, as they had existed in pre- and especially post-Columbian periods, had their linkage to ancient, pre-historic times. The knowledge about them may have been lost or the rituals would have changed over the centuries. Addressing a gender issue in ornamentation, Kerisit quotes DeMallie and Blundell by pointing out that in the Lakota culture of the $19^{\text {th }}$ century, women were believed to derive their power from deer (men from elk). The curved front yoke of the Blackfoot skin dress symbolized the deer tail, while the jingles on the Jingle Dance Dress were made from the dewclaws of the doe for the same reason of female power (1989:140).

The period of 'indirect European trade' (approx. 100 years), that is trade with European-derived objects without direct contact with native people, may have been significant as a transition from pre-history to history for aboriginal cultures. Trade items such as rings, beads, bracelets, copper scrap and tinkling cones were recovered from the southwestern Lake Erie region, dated between 1550 -1643 (Stothers in Genheimer 2000:52). Such objects would then have become 'objects of cultural revival'. From this vital proto-historic time period, Stothers lists a number of European-extracted trade items from the Indian Hills Sites (western Lake Erie) which were or may have been made into jingles and tinkles:

Sheet copper and brass tubular bead hair pipes;

coiled beads made of narrow strips of sheet copper, copper spirals, and iron droplets (in Genheimer 2000:57).

From this cultural readjustment period for Aboriginals in the Lake Erie region, we can move to the times of post-European contact which generally occurred over the northeastern Woodland areas. What were some of the newly evolved symbolic meanings of such ornaments as jingles and tinkles? As mentioned previously, among Woodland tribes (as well as many others), dreams were of primary importance, especially to 
shamans and healers of the Midé, but also (as among the Chippewa) to every member of the tribe, beginning in early childhood. For the treatment of the sick, the dream representation was of utmost importance. It could be in the form of beadwork on garments or other objects, jingles, tinkles or bells, certain animals, a blanket with a 'dream picture'. Densmore explains that the possession of a dream representation can secure the dreamer with "protection, guidance, and assistance". An inherent Indian belief exists by which "the essence of an individual or a 'spirit' dwells in its picture or other representation". According to the Chippewa, in dreams "they often return to a previous state of existence" $(1970: 82,79)$. Could there be a correlation between the dreams of previous existence and the use of certain ornamentation such as tinkles used on garments and those found in ancient burial sites?

Interviews with native Indians, including Jingle Dress Dancers, as well as the literature, support the belief that jingles, tinkles, and bells have the power to heal or to ward off sickness. The Ojibway believe that in the past, metal was used to ward off many of the bad spirits. Even in present every-day life, when people go to pray, to a sweat lodge or Sun Dance, a medicine man or elder will remove all metal objects from his body before conducting his prayer. No metal is allowed because the spirits are afraid of anything shiny and sharp. That is why the cones on the jingle dress are most important since they ward off the bad spirits (Meeches Video Production, n.d.).

Internet information, in contrast, points to a belief among healers (which includes New Age healers) that metals such as copper have "energy-conducting properties" that can heal the mind and body. Ancient Greek, Romans, and Egyptians "placed specific metaphoric importance" upon the clothing materials they used for certain types of rituals. Copper items were used in burial rituals and often placed on the dead body, i.e. copper mirrors (anon.[c], n.d.). Since copper cones and tinkles had been discovered in Woodland 
Indian cemeteries and mounds, could they have meant to provide the dead person with a healthier afterlife, a future life without sickness?

Since the 1970s, New Age healers (members of New Age Religions) have acquired certain aspects of ancient North American natives' healing practices. Copper, in the form of rings, bracelets or pendants, is believed to be a "powerful assistant" in preventing or healing arthritic and rheumatic diseases, increase energy, detoxify the body, and improve blood circulation (anon.[c], n.d.).

In conclusion, it seems expedient to point out some areas on the issue of 'cultural meanings' as explained by Diamond et al. They asked the questions as to 'how images communicate meaning'? In their research on drums of native people in northeastern America, they learned that images, designs, or symbols are either "seen" by individuals and are seen differently from one another, while other images and symbols are culturally shared by the group or community. The differences in 'individual meanings' are respected and "not discounted as wrong". Ethnographers, however, tend to acknowledge but simultaneously discount "individual interpretations" (1994:99, 101). How valid are individual interpretations based on personal experience ("esoteric"), compared to shared ("conventional") knowledge? Some Indians regard a drum with its images and symbols "as reflections of rich levels of meaning, symbolic concepts of cosmogony and identity" which are at the heart of Anishnaabe cultures. To others, the decorations are meant "to enhance the beauty of the object through its proper proportioning or skillful patterning". Several native artisans made the assertion that design, colours or ornamentations on musical instruments are for aesthetic enhancement rather than having any symbolic meaning. Natives "who describe meaning in symbolic terms" are usually "traditionalists", while the other group consists mainly of Christians, although a sharp boundary between the two cannot be drawn. Also, the Christian group should not be rejected as 
"acculturated" and having lost meaning, rather than having made an aesthetic shift. The authors also point to the different interpretations of symbols and signs on which the interpreter relies, according to the "different sign-types" available. According to Thomas Pierce's pattern, there is the distinction of "icon, index, and symbol" (in Diamond 1994:101). For instance, the image of a bird could be interpreted "iconically" as the thunderbird sign, "indexically" as something that refers to the "jingling sound of the instrument", or "symbolically" it could imply that the owner is a member of the Midéwiwin. Generally, their findings indicate that 'symbolic interpretations predominate'. The authors also point to two semiotic problems: Firstly, a symbol received as a "representation" is not the same as one received as a "transformation". Secondly, "the naming of sign-types draws our attention to the end product rather than to the process of creating or observing meaning". The process appears to be the most characteristic aspect of many interpretations (Diamond et al 1994:102).

In accordance with the findings of these authors it remains to be seen how individual and shared (or collective) meanings of ornaments like jingles and tinkles have affected the Jingle Dance Dress. This issue will be addressed in the section about the semiology of the dress, dance and songs.

\section{Producing the Dress and Dancing the Steps}

Possibly the earliest woman's 'jingles' dress stems from the Prince zu Wied collection of 1844. A colour photograph (Bolz, Sanner 1999:75) shows a rare Lakota dress from near Fort Pierre of 1830. It is made of animal hide, "folded on the right side and sewn together on the left". The lower border of the dress has a row of cone-shaped metal jingles to make "clinking sounds with every movement". It would have been worn on special occasions only; however, this dress went out of style after 1830 (1999:75). 
Despite its jingles, it was not called a jingle dress.

It can be said with certainty that the introduction of the Jingle Dance Dress by Maggie White (Ojibway) to the North American powwow circuit in the 1960s, contributed greatly to the progression of later transitions of its styles. Although different tribes claim to be the originator of the jingle dress (i.e. the Hopi), the oldest available photographs of aboriginal women wearing jingle dresses by that description are those of the Ojibway (1905), and of Dakota Sioux (1930). Those early dresses had at least six rows of metal jingles attached. The style and type of other materials used appear fairly simple and the only other ornamentation to the regalia were shoes instead of moccasins, wreaths in the women's hair, and possibly a hand-held fan.

A later photograph depicts jingle dresses of Mary Jane Littleghost (a Dakota from the Fort Totten Indian Reservation), taken in 1936, showing five rows of jingles which appear to be made from elk teeth rather than metal. Another dress from the 1950 s displays four rows of jingles. The dress material seemed to be cotton and adorned with cowrie shells, small metal bells and ribbons. The Dakota women during that time actually called this type of dress "Sda Sdana (jingle) sung sungnica (dress)". The jingles were usually 23" long. Such a dress would rarely be made by the family itself, but by a woman who specialized in making jingle dresses (Garcia in American Indian Crafts and Culture, Vol. 5, 1971:16-17).

From those 'simple beginnings' of the jingle dress in the early 1900s, a major transformation took place in the 1950s. At this stage, it is appropriate to take a closer look in which way Maggie White contributed to this change and its ultimate popularity. The various origin-legends of the Jingle Dance Dress also includes one about Maggie White. As a seven-year old child she suffered from rheumatic fever and was not expected to live. Her father was the first person "to doctor her". While taking care of her, he had a dream 
in which he was told to make a dress for her with metal jingles stitched on it. When the dress was finished, her father put this dress on Maggie and begun to sing. After a while, he asked her to stand up and dance to his song. As she danced, she gradually felt better and eventually was healed. Maggie continued to perform the Jingle Dress Dance throughout her life, developed her own style and dancing steps which gave the jingles their unique sound (Meeches Video Production, n.d.) (see Fig. 14). Maggie White thereby established a new tradition which lives on into the present, especially on the powwow circuit.

Throughout northeastern America, two major and different styles of the jingle dress are recognized - traditional and contemporary. The traditional style is divided into four individual styles: Southern and northern buckskin, and southern and northern cloth (Powers 1990:58-60). Since jingle dresses made of buckskin have become very rare and research did not reveal the production of such a dress, the focus will be on the contemporary dress. As already mentioned, the choice of design of each individual dress, its colours and ornamentation, very often are based on the woman's dreams or visions. When this is not the case, the fabric and colours used are those most popular at a given time.

One native woman from the Great Lakes region who sews jingle dresses, confided that she follows her dreams as regards the design and colours of the dress, but also 'adds on' to make the dress more contemporary. She remembered that the original jingle dress was quite plain, without a particular pattern with only one or two rows of jingles on it, while contemporary designs are often intricate with lots of details and many different colours. The dress' fabric can be satin or broadcloth (Meeches Video Production, n.d.). J. and $M$. Johnston also mention cotton and taffeta, used with solid colours, but occasionally "with a small overall print or a jacquard (design of the same color woven into the fabric 


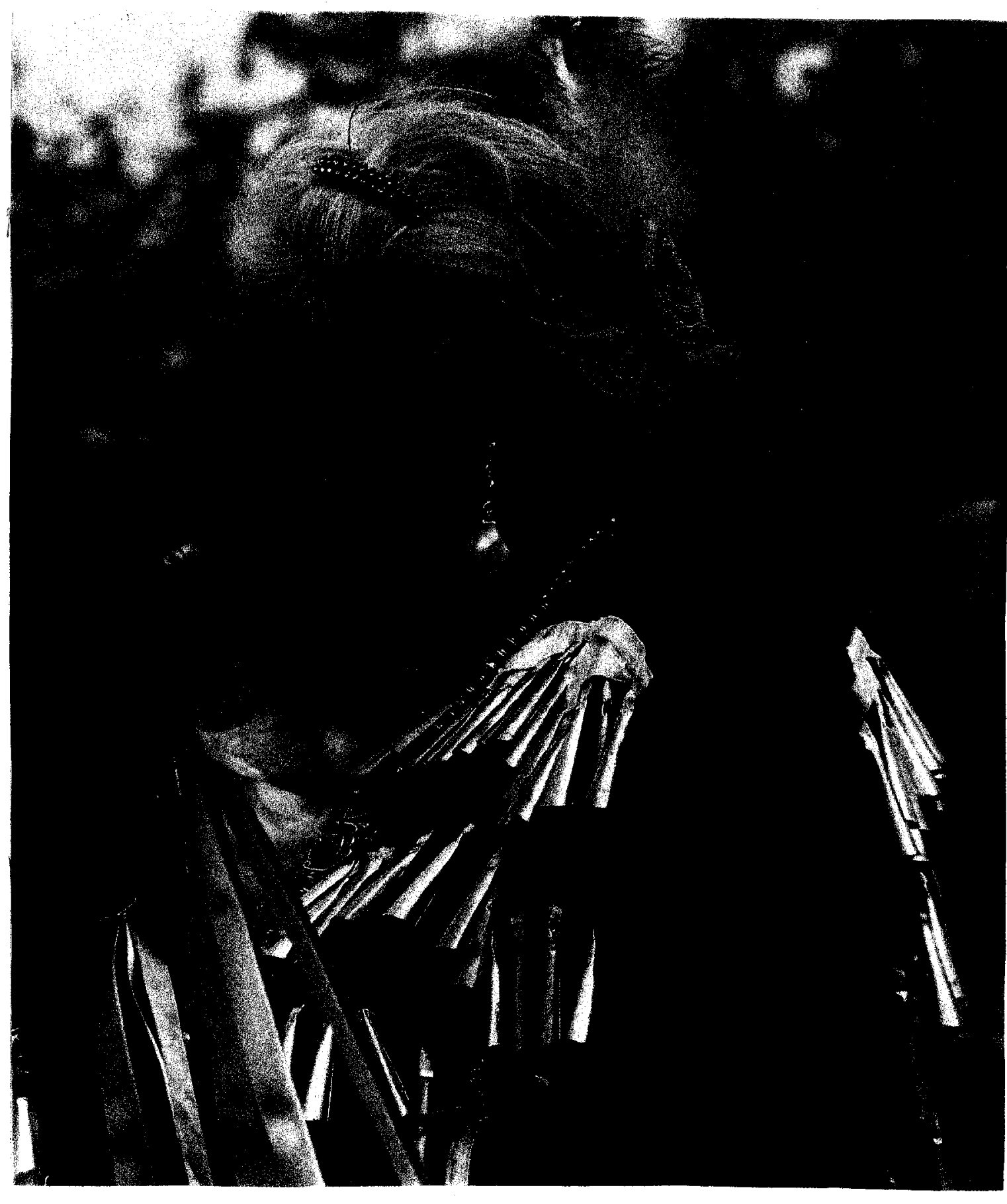

Maggie White particpates in the windy Boy Family Giveaway

Marra, Ben, "Powwow - Images Along the Red Road" (1996) 
such as green on green print) are seen". Most importantly, the fabric has to be strong enough to hold hundreds of jingles. On light-weight material, it is recommended to use lining for extra durability (Johnston, J. and M. 1991:7).

My interviews with jingle dress dancers revealed that the design and production of the dress as well as other parts of the regalia may be of great importance to one woman, but not to another. One dancer followed precisely the vision in her dreams as regarded the colours of the dress and placing of the cones. Another dancer, who received her jingle dress as a gift, would not have objected to one from a mail-order catalogue. Her main concerns were the size and numbers of the cones so they would produce the proper sound when dancing. The dance style, the steps, the songs and drums were other elements which had to come together in order for her to be a successful Jingle Dress Dancer.

The three major styles of jingle dresses are worth describing: The cobbler-style apron, the dress with underskirt, and the flap dress. J. and M. Johnston describe the cobbler-style apron as being worn over the dress. It is "a large piece of material to fit from the shoulder to the hem of the dress in the front and back", with a string tied around the waist. This apron can be worn over different under-dresses, with the advantage that it can be pulled up in the back, enabling the wearer to sit down when not dancing. Instead of an apron, a skirt can be made to fit over the dress which would also enable the woman to sit down after pulling up the skirt. This 'over'-skirt then is decorated with ribbons with the jingles stitched on. The flap dress has a flap attached to the back of the skirt-part of the dress. This flap can be lifted up, again for the purpose of allowing the wearer to sit down. Numerous variations exist as to the decorations at the top of the dress. Capes and vests made of different materials and ornamented with ribbons, beads and jingles are among the popular ones. These may be a transition from Fancy Dancing to Jingle Dancing (1991:78). Some contemporary dresses are decorated with old lace around the back and shoulder 
(Windchief 2002:20).

One of my informants pointed out that it is not vital whether the woman will saw the dress herself, has it made by a seamstress, given as a present, or even bought readymade. It is of utmost importance, however, that the jingles for the dress are made of the right type of metal (usually from Danish tobacco tin lids), in the correct size, and be stitched onto the material in such a way as to produce the proper jingling sound when dancing. She made the first jingle dress herself, but made the cones too small and too narrow to create the right sound. Miller mentions that contemporary dancers also decorate the cones with such images as small feathers that are pressed into the metal (1995:67). How such an addition would affect the sound of the jingles is not described. Diamond $e t$ al explain that the correct number of jingles "can also relate to the aesthetics of sound". Apart from the 'right' sound, those jingles are also 'indicative of process'. The production should, ideally, take a year, with one cone added per day (1994:146).

There are variations of pattern to construct the dress, though most are of the Tshape. It is not necessary here to describe any patterns in detail or the types of materials and colours used, but rather to focus on the cones or jingles. As J. and M. Johnston note, the dress itself does not require a great deal of skill to design, due to its straight lines and seams, and sewing patterns for the jingle dress are almost endless. The shapes of the ribbons on which the jingles are attached can be V, W, U, and zigzag (1991:10).

Before discussing the most essential part of the dress, the jingle cones, it had to be mentioned that among the eastern Woodland tribes, in particular the Ojibway, the encounter with European traders introduced them to the tin tobacco snuff lids in the $18^{\text {th }}$ century. Those tin lids may have replaced copper as material for the production of ornaments and become part of their material culture (Jasper 1988:21). Whether Indians used materials from their natural environment such as shells or deer hooves, or whether 
copper sheets or tin lids were fashioned into jingle cones as pieces of adornment, the important idea was to produce objects of sound, for spiritual, religious or temporal purposes.

As with the dress itself, there are differences of opinion and therefore variations regarding the type of metal to be used, the number of cones on a dress, and the sound these cones should be emanating. According to my informants, the contemporary dress quite often is decorated with more ribbons, even feathers, and with fewer jingles. Some women still insist on the number of 365 jingles on the dress, one for each day of the year, with an extra jingle added for every year she has danced. One woman suggested that the jingles are not necessarily counted anymore, that jingle dancers use 'what feels comfortable, what looks right, more like a design issue'. Some dancers prefer heavy cones, others lighter ones, since they are easier on the body. Although the cones are supposed to be made from the tops of tobacco can lids, some people simply buy a piece of metal and cut the jingles into shape. Either way, to produce the jingles is very hard work. As one interviewee remarked, thirty years ago the jingle dress was a plain, old-style dress, with the cones on the top of the dress and on the sleeves. Nowadays, appliques, not jingles, are attached to the top part of the dress. Morris Bernstein mentioned that the jingles on older dresses are longer and some women add four extra jingles for the four directions (1996:119). Fig. 20 provides a visual impression of how the tobacco tin lids are turned into jingle cones.

Lastly, what accessories are worn with the jingle dress? These depend to a great extent on tribal culture and how the Jingle Dance Dress originated within the tribe, as well as on personal choice. The most elementary paraphernalia are moccasins, leggings, belts, bags, fans, scarves and slides, and hair ornaments. Moccasins can be seen fully or partially beaded, quilled and sequined among Woodland tribes, while some Plains Indians 


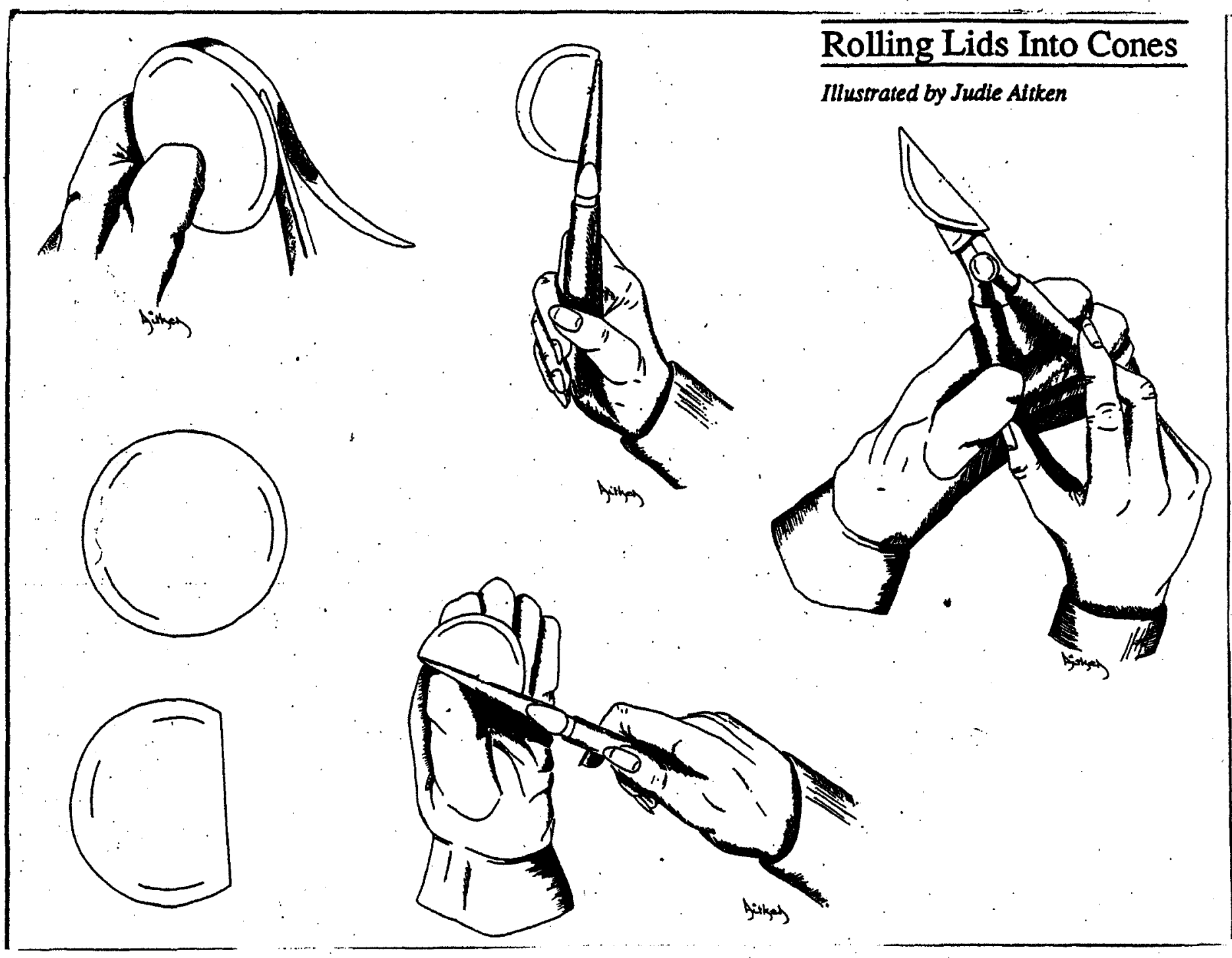

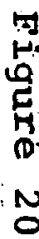

J. and M. Johnston, "Jingle Dresses" in Whispering Wind, Vol. 24, No, 2, Summer 1991. 
wear boots. Similarly, leggings may be beaded, sequined or appliqued in either traditional or modern styles. The belts worn are also beaded, sometimes added with a matching beaded buckle. Bags, though not a necessity, are carried by some women. They can be of different sizes and shapes and either for utilitarian or decorative purposes, and are always carried in the left hand. A vital part of the regalia is the fan, to be carried in the right hand. This item will be discussed in the next section. Scarves are usually worn around the neck or as a bandana. They may either match or contrast the ribbons and beadwork of the regalia (J. and M. Johnston 1991:10-11).

Hair styles and hair ornaments are another essential part of the regalia. Most popular is one braid worn down the back with a large barrette worn at its top, decorated with a single feather. Other barrettes are worn at the bottom of the braid as well as on the sides of the head. Some women prefer to wear two braids, worn in the front and again decorated with barrettes with a feather or fluffs. Another popular hair style is French braiding with either a single back braid or two front braids. Beaded barrettes again keep the hair in place (J. and M. Johnston 1991:11).

\section{Symbolism of Regalia, Song and Dance}

In ancient times, Indians viewed illness as an unknown, mysterious occurrence. As spiritual people, they depended on powers beyond their control to enable them to deal with their daily trials such as sickness (Windchief 2002:16). Shamans performed their specific rituals to combat those forces, and healers, medicine men and women, used natural remedies such as herbs to cure the afflicted person. Just as many dances of the past and up to the present are social in nature, others are ritualistic for the purpose of conjuring, or to prepare for war, so has the Jingle Dress Dance evolved into a healing dance, albeit a fairly recent one among the Woodland tribes. One aboriginal woman 
(interview with Sexsmith) asserts that the Jingle Dress Dance tradition goes back two centuries. According to Windchief, however, this dance has been performed as "part of the original celebrations of the Northern Plains tribes" (Sexsmith 2001; Windchief 2002:16). The literature does not support either claim.

The creation of the jingle dress was the result of a man's dream, of a sick girl's wearing of the dress, dancing in it, and of being healed. Both dress and dance became synonymous with the power of healing as well as the power of dreams. Focusing on the dress itself, I think it is difficult for non-native people to understand whether, or to what extent a dream, or several dreams, actually determine a woman's vision of what her jingle dress should look like, or whether other possible outward influences also play a role. Miller explains that in Anishnaabeg traditional culture, men and women have dreams, though men more often seek visions than women do. Especially during the woman's menstrual cycle, she was to pay close attention to her dreams, since this was the time "she was most powerful as a woman". The Anishnaabeg consider her as "closely connected with the earth mother", because earth is life-giving. Even little girls are encouraged by their Elders to be aware of their dreams, so they will know if they are called to eventually become jingle dress dancers. In her dreams, the dreamer is always shown how the dress is to be made, whether the jingles should be gold- or silver-coloured, the number of rows and number of cones, whether the rows should be straight or geometric (1995:34-35, 61). The colours of the dress may be given in a dream or they may be the colours a woman received at the time of her naming and therefore have become part of her individual identity. Those colours have meaning only for the wearer and are not to be disclosed to others. They "are significant to the spirit realm" and indicators of the gifts the woman has received from her helpers. To wear those colours as part of her regalia, she honours the gifts of those spirits. Miller emphasized that, although the dress has to be made as seen in 
the dream, this does not exclude later additions or changes to the regalia. The jingle dress is not static, but the dancer will always be guided by the spirit through her dreams, especially as to the style and colours of the dress. The spirit will bestow the gift of healing on the dancer $(1995: 61,73)$.

Through my personal interviews (and those of other scholars) with Ojibway jingle dress dancers, I became aware of the very individual aspects of the jingle dress regalia and the way in which the dances are performed. Apart from the significance of dreams, other elements can enter the process, especially for individuals and families who follow the traditional teachings, rather than the contemporary powwow principles. Some young daughters who wish to become jingle dancers, first undergo a fast, either voluntarily or because of a parent's request. The fast may be for the duration of each monthly 'moon cycle' during which time they are not allowed to pick or eat berries, in particular strawberries. It is called a "berry fast" and extends over the whole year. Strawberries are a woman's medicine; they are the first berries of the summer season, symbolizing that the girl becomes a woman. During that year of fasting, girls are also taught "how to take care of themselves"; they are not allowed to attend dances or have boyfriends. Only after the fast-year ended, is the woman considered ready to wear the jingle dress and become a dancer. The dress has spirit, it has healing powers, 'bringing goodness' to the family and community.

The woman's one-year fast can be from any other type of food. It is essential that she demonstrates self-discipline and sacrifice. Each day during the fast she would attach another jingle to her dress and, by the end of the year, she would be ready to become a dancer (Meeches Video Production, n.d.). One woman informed me that in her culture as an Ojibway, 'dreams are really, really important, they tell a great deal about what will happen in our life, giving guidance as to what we are supposed to do in various 
situations'. Hence, recurrent dreams revealed to her a jingle dress. At first, she 'just heard the cones, how beautiful they sounded, also the drum', then she saw the style and design, the colours emerged more clearly, and how cones were to be placed on the dress. She could see the moccasins, saw herself dancing, for her family, her community, the children and the youth. At first, she did not see the face of the wearer in her dreams, but eventually she saw herself in the dress. Those dreams lasted for about a year during which the woman was still 'dancing fancy' at powwows and other gatherings. Unable to ignore her dreams, she consulted a friend, presenting her with tobacco, as is the custom. Obviously, those dreams were giving her a message. She decided to make a jingle dress, 'took tobacco, put it out and talked to the Creator', asking for guidance about the jingle dress. Finding a seamstress she knew, she brought her also tobacco and instructed her how the dress had to be made in accordance with her dreams.

It is of significance to draw attention to the fact that before and during the times of her dreams, there were problems of identity, behaviour, and alcoholism in her family. She was aware of the jingle dance dress as a healing or medicine dress. Did her dreams subconsciously guide her towards becoming a healer, wishing her own and her family's troubles to be cured? Once she introduced the jingle dress into her family and community, positive changes took place all around her. The dress has spirit and that spirit, according to the Ojibway informant, brought goodness to the family and community. The regalia, she pointed out, is worn usually at traditional as well as competition powwows, and sometimes at naming ceremonies. Since two basic types of powwows exist (traditional and competition), in the beginning she performed the jingle dress dance primarily at traditional powwows, but later also 'drifted' into the competition part of such gatherings. Then a change of a spiritual nature occurred in the dancer. Becoming increasingly aware as to 'how much power that dress can have', a power that 'comes from within yourself'. 
Wearing the jingle dress and dancing in competitions 'did not feel right' to her. At first, she ignored this feeling, but then began to remember the teachings of the jingle dress tradition, its healing aspect. As Miller has put it, "The spirit will aid the dancer and her people through the gift of healing, so long as the dancer followed the instructions given by the spirit." The dancer needs to be respectful at all times towards the dress, the sound of the jingles, the dance steps, the communication she once received from her helper spirits (1995:73-74). Many of my informant's Elders presented her with tobacco, requesting that she dance the jingle dress dance for them when someone was in need of healing. She remembered one particular Elder who was in poor health. She danced for him because he could not attend powwows anymore. She was happy to dance and pray for him, 'to give him the strength to continue to walk that traditional life, to walk that traditional road'.

Eventually she changed to Fancy Shawl dancing. To this day, she feels that the Jingle Dance Dress should not be part of the powwow circle, stating that it was never meant to be a competition dress. It was a healing dress that brought 'many good things' to her community. Here, Miller also emphasized that the Jingle Dress Dance is specifically for mental and physical healing, and also "a dance for those who cannot dance for themselves". Among the Anishnaabeg, the dancer's ability to heal, bears strong spiritual meaning, "granted to individuals by the spirit". It is the sound of the jingles on the dress and the drum which call the spirits "to do their healing". The dance is a "spiritual event that creates contact with the divine in distinct culturally accepted ways" (1995:12-13).

In this 'spiritual (and cultural) context, my interviewee's realization that she had been called by the spirits through her dreams to become a jingle dress dancer, and thereby a healer, was of great significance to herself and her community. The issues of traditional vs contemporary competitive jingle dress dancing will be discussed in the last chapter of 
my thesis. In this context, however, one aboriginal male dancer suggested to jingle dress dancers 'to step back a bit, listen to our Elders, our powwow Elders, our medicine people. Powwows have somewhat deluded the true purpose of the jingle dress. We hear so many misconceptions and interpretations that aren't really, truly traditional' (Meeches Video Production, n.d.). In this spirit of traditionalism, it is an established custom for a new jingle dress regalia to be "feasted". Miller explains that "Dancers must feast their dresses before they may dance in them". During the ceremony, the new dancers then receive tobacco in exchange for their favours as healers (1995:14).

Feasting a new jingle dress is usually a communal affair, and such celebrations vary from one community to another. An example is provided by Berbaum in which a woman, holding a child by her hand (it is not clear whether the child was necessary for the ceremony) "makes a circle alone". Then women in jingle dresses join her and all other dancers follow. Although a song and dance for feasting a jingle dress were performed, it was unclear whether the ceremony was for a new dress or particularly for this person, or possibly linked to a dream (2000:16). Another example is described by Miller in which the feasting was a family matter with four Anishnaabeg women in attendance who were already jingle dress dancers, while another decided to feast her dress at a powwow. There, she was presented with a bottle of maple syrup. The bottle broke and the syrup spilled over her jingle dress. The woman determined that "the dress had feasted itself". Maple syrup, also called "sweet-water" is regarded as an Anishnaabeg standard food for feasting. The feasting food, which may or may not be prescribed in a dream, can also be other traditional food such as wild rice and venison $(1995: 63-64,74)$. Obviously there are many variations in feasting ceremonies, whether they are conducted within a family or a community.

Already during the early years of Maggie White's life in the 1920s, after the 
healing of her sickness, the jingle dress was called shay 'bawsh 'kay'gun, in Ojibway language, meaning "something moving with sound". The dress is thereby considered a sacred object because it was given in a dream as a gift from the Creator. In turn, Maggie White, due to the special honour bestowed on her, became the "keeper of the Jingle Dance Dress "(Walker 2001:84, 88). In the case of my Ojibway informant, it had been decided by her dressmaker, an Elder, and by other people involved, "to do a feast for her dress" at the time she had received a clear vision as to how her jingle dress would look like. She was then instructed about her responsibility in taking care of the regalia, putting food out there for the dress, and not wearing it during her 'moon time'. When the dress is not in use, it must be hung up, preferably among the cedar trees. Food needs to be out for it once in a while for four days and four nights, especially when the season is changing. It can be any type of food. She was taught to follow those instructions, although, she pointed out, they may be difficult to abide by for native women who live in the city. Nevertheless, food and tobacco can be put out for the dress. What happens to the regalia if a dancer decides to change to another dance tradition? Such a decision would be made by the individual or the family. My informant gave away most of her dresses, keeping only two to wear at powwows, but not to compete them. In the case of a dancer's death, again the family may decide to pass the regalia on to a relative. It does not 'just sit in the closet', but is passed down to somebody who will use it 'in a respectful and deserving way'.

I was not informed about how the feasting ceremony is performed. It can be assumed that this is a private or even sacred affair within some families or within close communities. Very little is known about the first Jingle Dress Dance. Even the oral tradition (the legend that had been told originally) never mentions the type of song to be sung and the type of dance steps to be used when wearing the jingle dress. When those 
women danced for the first time to the sound of the jingles, what steps did they dance? We only know that the sick girl was healed of her sickness after four days of dancing. A jingle dance song may not have existed; the women may have simply 'moved' to the sound of a drum. What is known, however, from North American natives themselves, from observations and historical records after European contact, and from extensive research by scholars, that dancing had always been an integral part of Indian life. R. and G. Laubin provide a summary of recorded dances by various explorers (Jonathan Carver, John Long, George Catlin, etc.) from the mid-1700s to the mid-1800s. Most of the listed dances are those performed by men and only two dances by women of the eastern Woodland tribes, namely the "Women's Medicine" and the "Women's Dance" (1979:50$51)$, indicating clearly that some women were regarded as healers centuries ago.

Due to the great importance of dancing for North American Indians in general, it has to be mentioned briefly how Europeans during early contact with Indians viewed this ancient tradition. In their eyes (R. and G. Laubin), all Indian dancing was "war dancing", therefore it was feared and consequently every effort had to be made to discourage or even suppress it. Dancing was a major expression of Indian culture "to come under attack" by missionaries, governments, and educators. The Sun Dance of the Plains tribes (i.e. Sioux) was outlawed in the USA in the early 1800 s. Such a suppression crashed the social, political, and spiritual life of a native tribe. "Dancing was the most Indian thing about Indians" (1979:80-81). This domination included such practices as "Indian medicine". As one Indian woman (Hinto Agliwin) remarked after the ban on dancing had been removed, "When they stopped our dancing we died. We stopped living. We felt there was nothing left to live for". By then, a whole generation had "been effectively removed from direct contact with the dance". The authors further explain that closer observation and study in the early days of contact would have revealed that dancing was 
the "focal point of all their material culture, and the highest expression of their mystical yearnings", it was the soul of a people, a kind of prayer, and "communication with the surrounding spiritual forces. Life was dancing, dancing was life" (1979:81, 83-84).

In the decades after the ban on dancing had been lifted, there emerged not only a revival of some of the old, traditional dances among Woodland Indians, in the USA and in Canada, but many new kinds of dances and songs were created. More often they were of a social rather than a sacred nature, and the regalia became more and more ornate, partly due to the growing popularity of such gatherings as powwows and their competitive aspect. Prokosch Kurath points out that women in the eastern as well as in other areas, took an important part in native group dancing, but were excluded from male performances. Women's style of dancing tends to be more conservative and uniform than that of the men (1986: 237).

At the beginning of World War I in 1914, Maggie Wilson, an Ojibway and female shaman, who experienced vivid and detailed dreams throughout her life, had a dream about a particular dance which returned to her nine times. She called it Star Dance because of its "heavenly origin". The arctic owl and the Thunderbird appeared in her dreams; they taught her eighty songs, the design of a drum, ceremonial staff, pipes, and the costumes. Bells were to be attached to the drum and staffs, and beads on the dresses and headbands. "Because sixty Thunders shared in the dream, she engaged sixty villagers to represent them in her dance" (Landes 1968:208-209). Sometimes, this dance is referred to as war dance, but Maggie Wilson, in her dreams, understood it to be a dance that would bring the soldiers back form the war. Therefore, many of the soldiers' relatives joined in the dance, believing in the Thunderbirds' protection and blessing. Those who came to the dance brought tobacco, food, and printed cloth as offerings to the Thunderbird. The dancing would last two to four nights, five-times a year, at Christmas, 
New Year, spring, summer, and fall. For various reasons, however, the mystic Star Dance was given up eight years later and the Ojibway converted to Christianity. Maggie Wilson affirmed that many soldiers' lives were saved, but many died (1968:212).

Was the Star Dance the forerunner of the Jingle Dress Dance? Maggie Wilson's dreams and subsequent dance and regalia occurred much earlier than Maggie White's (1930s). The dress on the photograph depicts at least five rows of jingles. Landes does not mention whether the dancers were all women or whether the men joined in, wearing a different regalia or none at all. There is no reference to 'healing or medicine', only to 'the safe return of Indian soldiers' from the war. Landes also does not explain how or whether the jingles on the Star Dance dress were linked mystically to the dance, or what type of steps were used at that time. It seems certain that the Jingle Dress Dance tradition earnestly began with Maggie White and her legend with its link to medicine and healing practices.

The Archives of the Canadian Museum of Civilization holds a fairly large collection of sound track recordings. My research included listening to approximately a dozen songs which ranged from the period of 1912 to 1959 , sung by members of the Ojibway (Anishnaabe) and Mohawk and Haudenosaunee (Iroquois). Only four songs could be identified as medicine and healing songs, and included a prayer said by Gertrude Kurath (Manitoulin Island), accompanied by music, 'The Mother's Dance', possibly Iroquois, sung by a male, and several 'Women's Dances' (Ojibway) with drumming and songs performed by males, a woman with a rattle, and a child (Canadian Museum of Civilization; Audio Archives). There were no references to jingle dances or songs. These findings indicate that the composition of jingle dress dances and songs began with or around the time of Maggie White.

Prokosch Kurath explains that virtually all Eastern Woodland tribes "favour the 
stomp-step, an earthen shuffle with regular pulsation in elastic knees", in which the right foot leads and the left foot is pulled up alongside. Other steps "pound the earth with forcible heel emphasis", the "stomp-kick", used in most medicine rites (1986:238). The author describes the women's style as "decorous with arms close to the body and small steps", and everywhere in the east, the women's dance is made up of "a sideward twisting, sliding motion", especially among the Iroquois and Shawnee (1986:237-238). (see Fig. 21)

We do not know anything about those very first songs and dance steps that were used, or the kind of drum being played during the original jingle dress ceremony. $R$. and G. Laubin point out that Indians continually compose new songs for dances that were created and introduced a long time ago. Although nowadays they are able to use modern technology to tape new songs, they have an excellent memory for listening and learning new songs, even from different tribes. Indians regard all songs, including humorous ones, "in a certain religious light", and sing in a high, quavering voice in order to be close in approaching "the strange world of the spirit which is the true realm of song". Some Woodland tribes used symbols (mnemonics) on birchbark to recall songs which were passed from one generation to another. It is important to note that "Indians sing in unison, not in harmony", and whenever women are invited to assist the men with the singing, they sing an octave higher $(1979: 89,90)$.

There appear to be no oral informants from the earliest time of the jingle dress dance, and the literature does not inform us about the music and dance steps for the jingle dance before the time of Maggie White. It was therefore due to her innovation and individual dance style, which later became known as traditional, that was adhered to by other dancers among the Ojibway as well as other Woodland tribes. Walker remarks that Maggie White became known as the "First Lady of the Jingle Dress Dance". It is assumed 


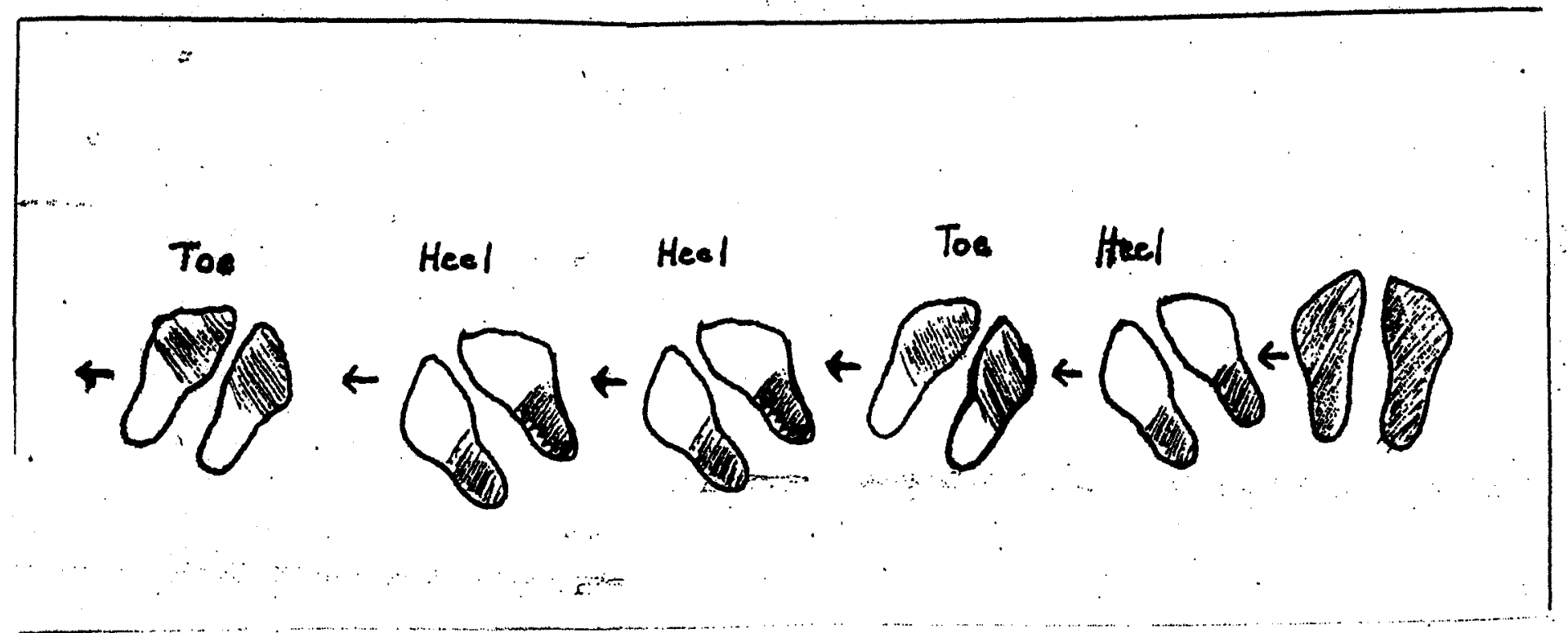

Slide Dancing
body weight from the balls of
your feet to the heels while
sliding your feet along the
floor to the left. This is
repeated over and over during
the song.

J. and $M$. Johnston, "Jingle Dresses" in Whispering Wind, Vol. 24 , No. 2 ,

Summer 1991. 
that through her not only the jingle dress, but also an older dance style had re-emerged, together with "traditional Indian values based on love, honor, respect, and generosity". Maggie White insisted on the observance of those values and traditions by all jingle dress dancers $(2001: 82,90)$. Among the Anishnaabeg, traditional jingle dress dances, unlike contemporary ones, are very slow, can also be danced by older women, where the dancer always must have one foot on the ground to spiritually connect to Mother Earth and its healing powers. It is to be understood as a prayer for the earth. These slower steps are said to closely tie the dancer to the healing nature of the dance, an important sacred connection (Sexsmith 2001:6; Miller 1995:41-42).

It must be stressed that the power of the jingle dress is in the jingles; their sounds and the music communicate in some way with the spirits, the drum setting the pace. "The sounds call on the spirit, and remind the spirit of the promise that it has made in the dream". Miller further explains that "dreams, music, dance, feasting, and tobacco are all integral parts of the dance", and create links between the dancer and the spirits who promised her to help". Unlike the dress, the dancing steps are "more constricted" since they must follow the beat of the drum. Yet, changes have occurred since the early 1900 s, though new dance styles since Maggie White have not been rejected (1995:76-77).

Experienced jingle dancers inform us that to learn dancing it must be seen, observed from other dancers, and practiced, not only the feet, but the whole body movements. In a dance arena (i.e. a powwow), such steps as the two-beat step, the shuffle step, the crow-hop, the sneak-up, or the slide step (jingle step) are used. No spins, kicks or flashy movements are allowed, the feet are low to the ground and very fluid, smooth and soft. The style is flowing and graceful, the body posture straight and erect. The most unique style is the slide step, following a loud drum beat. The drummers will sing the song four to six times, then stop. These songs are usually performed during contests or 
exhibitions. The dancers move sideways or around the arena. There are variations of the slide step and every dancer has her own favourite one. During the dance, the left hand is placed on the hip and the feet side by side, then the body weight is shifted from the balls of the feet to the heels while sliding the feet along the ground to the left. With relaxed knees and body flow, the jingles will be able to sway sideways, making a "shushing" sound. During the drum's "honor beats', the dancer raises her fan to honour the Great Spirit or relations who have died (J. and M. Johnston 1991:11-12).

During my personal communications, one Ojibway jingle dancer confirmed that steps are learned by observation and that the traditional steps are more popular since women of all ages are able to dance them. The movements are either forward or sideways; others are zigzag which signifies that 'life is not straight but has twists and turns like bumps in the road'. One of the women liked her children to dance, to observe the steps as soon as they could walk, if only for fun. The drummers in their communities are always men, though women may at times be back-up singers, a practice that appears to be fully accepted by the women. The songs can be with our without words, in Ojibway or in English. Words of the songs are seldom written down; they have to be remembered through listening.

Another informant noted that even the traditional side-step has undergone some changes in the past ten years. It is more a 'tiptoe' which it was never meant to be. To raise the fan during the honor beats signified 'pushing away the sickness, or bad thoughts'. When a first-time jingle dancer is brought into the circle, she can select four (the sacred number) other experienced dancers to guide her, to be her mentors who would teach her the responsibilities of a jingle dress dancer. They all dance behind the new dancer who has presented them with tobacco. After the first 'round the circle' dance, members of the community would come out to congratulate her and welcome her into the circle. This 
would be followed by a small 'give-away' for being welcomed, for having become part of the whole circle. The new dancer could also pass strawberries around to those who welcomed her. This way, other dancers will know her as a new dancer and assist or teach her to become a good jingle dress dancer. In her community, the men only are the drummers and most of the songs they compose for the jingle dance are chants. Their songs or chants rarely contain words; if they do, they are in the Ojibway language or in other languages. One drum is played by five to twelve drummers who are also singers, with a lead singer who knows the song. He is also responsible for taking care of the drum.

How many jingle dance songs have been created in the years since Maggie White introduced the tradition into the powwow circle is improbable to determine. One of the CDs I acquired plays as many as twenty songs with such titles as Whitefish Bay, White Eagle, Medicine Drum, Northern Wind, Two Feathers, Eastern Eagle, and others. Berbaum included several pages of earlier musical notes of jingle dance songs. Although the name of the singer and drum group, as well as the geographic locations are cited, no dates of the compositions or performance are presented (see Figs. 22a, 22b).

\section{Relationship to Family, Community, Powwow, and Gender Issues}

Little Jenna watches her Grandma Wolfe bounce-stepping in a jingle dress, daydreaming at the kitchen table. Jenna wanted to be a jingle dress dancer, but her dress still needed three more rows of jingles. Aunt Sis and cousin Elizabeth will lend her jingles if she will dance for them. Together with Grandma Wolfe, Jenna sews on jingles to finish her dress, her dance regalia. Jenna is of Creek and Anishnaabeg descent, belonging to the Muscagee Nation. She is told stories of animals and birds in the Great Lakes region, stories of the origin and purpose of the jingle dance dress, on the themes of healing and prayer, as well as the significance of a "giveaway" by a new dancer. The following week, 
Jenna jingle danced at her first powwow (Leitich Smith 2000:9, 14, 18-19). This story from a children's book illustrates the significance of instilling native tradition and their practices in a young person, their importance to family and community. As one informant remarked, 'I let my daughters dance as soon as they could walk, even though they did not understand the meaning of the dance'.

Native children may not be aware that the jingle dress is a medicine dress, may not understand its power and sacredness, but as they grow up, they gain "respect for the healing power of women and their connection to Mother Earth", as Sexsmith puts it. The young Ojibway learn that the original jingle dress was simple and the dance modest and more reflected the healing power and the dignity of women. Even by the mid-1900s, tribal Elders did not allow jingle dress dancers to wear plumes, carry feathers or fans (Sexsmith 2003).

Apart from the Elders' teachings at that time, it could be said with certainty that Maggie White's insistent teaching of the traditional Jingle Dress and Dance contributed greatly to the high esteem it gained from the period 1960 to 1980 among the Ojibway, other Woodland as well as western tribes. Whether the women who followed her discipline and thereby helped to popularize the Jingle Dress Dance, did so because she was a woman, cannot be determined. J. C. White states that “Women's Traditional Dance is as old as the history of Native dancing", but in ancient times women used to dance in a circle at the edge outside the dance arena. While the men danced, the women were to "keep watch over the safety of the village" (1996:42). Since Maggie White's days, women have been dancing inside the circle, just as men have always done. It is up to speculation whether white women and the Women's Movement played any role in this change of tradition, including the fancier jingle dress regalia and dancing steps since the 1990s. Sexsmith's interviews with jingle dancers revealed the present-day popularity of 
the contemporary style with its fancier steps, feathers and plumes, and elaborate beadwork on the jingle dresses, "trying to catch the judges' eyes" at powwows. She found that with this style "the spiritual meaning of the jingle dress will be lost". A traditional dancer voiced her opinion about the beauty and dignity of the traditional style when women dance "in unison with low dignified steps", and the rhythmic sound of the jingles are like ten-thousand raindrops on a tin roof. Traditional dancers admit that they are becoming a rarity (Sexsmith 2001).

In the opinion of an Ojibway Shawl Dancer, women now stand in the middle of the arena because their generation is trying to be strong. Indian women don't voice themselves like Black people do (Morris Bernstein 1996:120). By dancing inside the circle, it appears that native women have not only become more visible, demonstrating their assertiveness in their own communities, but also to non-natives across North America. Boye Ladd (a Winnebago Fancy and Exhibition dancer) in his interview with author Chris Roberts, on the other hand states that the Jingle Dress Dance, like the Grass Dance, has always been here; its style is trendy. "Trends, styles and fads spread from tribe to tribe, and ebb and flow in popularity"; we always borrow from each other. The jingle dress is not new, but fads often bring out old styles, so they become "rediscovered" (1992:83). Ladd's statement would indicate that the jingle dress existence was known to many Indians of the Woodland tribes, but new dancing trends prompted it to be rediscovered. Fads, whether for jingle dancers or grass dancers, are therefore quite acceptable to him.

Frequently one reads in the literature and interview transcriptions about the impact the Jingle Dance Dress had on individuals and their families. As one woman explained, '... when spring starts, that is the time for the healing dress to help me for the whole year; I take the jingle dress and the fan that I carry, take it to a drum and ask that drum to sing; 
that is where I get my healing from'. The Jingle Dress Dance has brought her and her daughter closer together as a family, and they find their own medicine in the jingle dress (Meeches Video Production, n.d.).

One of my informants mentioned the necessity at times of taking youth from an urban environment to a rural native community, since a culture-based society would assist the young person in the process of healing from such problems as alcohol- or drug addiction. Part of a culture-based programming could consist of social or cultural gatherings such as powwows, sweat lodges, and outdoor camps. S/he will also become aware not only of the aboriginal 'life cycle', but also of the customs, practices, and beliefs of other Nations. For such a person, the learning of traditional values is of utmost importance. The Jingle Dance Dress tradition could be part of a healing process for a young female, although in his practice of providing guidance it has not been the case. He emphasized the importance of traditional native medicines and that western medical science should "take to heart the seriousness of what our ceremonies are all about". They help young Indians to rebuild pride, dignity and integrity, and teach responsibility in maintaining a healthy lifestyle, to recognize the gifts of the Creator. Just as aboriginal people will not reveal their medicinal knowledge to non-aboriginals, "the Jingle Dress ceremony is a specific sacred ceremony for healing and you may or may not obtain the indepth information relating to the true traditional value of that dance ceremony. Each Nation has different views in regards to different ceremonies. That's what is so unique about it" (interview, Oct. 2006).

The last question to be answered is the Jingle Dress Dance's link and significance to the 'world of the powwow'. North American powwows are a major subject which has been studied by numerous scholars over the past decades. My focus, however, is primarily on the Jingle Dance Dress and its links to the powwow. According to Boyer, the word 
'powwow' is derived from the Eastern Algonkian word pahwayau "which once referred to a gathering of medicine men". Early Euro Americans anglicized it to 'powwow'. Before the $20^{\text {th }}$ century, various First Nations' societies would gather throughout the year to celebrate, plan, administer or conduct important activities. Such meetings were accompanied by a "Spiritual Feast" which included songs and dances (Martin and Boyer 2000:7-8). Parfit, on the other hand, believes that powwow dances originated from such major Indian activities as warfare, healing, and the hunt (1994:107), the origin most of the literature refers to.

In the early $20^{\text {th }}$ century, Indians' newer lifestyles on reservations greatly reduced the significance of these gatherings. During the 1920s, though, a new type of powwow began to evolve, a powwow that "became a rallying force for twentieth century cultural survival", a place for young Indians to learn to dance, to sing, to drum (Martin and Boyer 2000:7-9). Two types of powwows emerged - the traditional, community-based, and the contemporary, contest powwow (Johnston and Nahanee 2003:7). Over the next several decades, powwows have become "a metaphor for the resiliency of First Nations culture", and as "Indian culture continues to thrive and evolve, the powwow is at the center of its growth" (Martin and Boyer 2000:52; Roberts 1992:8). These gatherings became a focal point of growing self-awareness as Indians. The Jingle Dress Dance has become a staple and vital factor in this evolution, especially since Maggie White introduced it into the powwow circuit, together with other women's dances such as "Traditional" and "Fancy Shawl". Walker explains that participants and spectators, during the Pan-IndianMovement of the 1960s and 1970s, began to observe Ojibway women dance the Jingle Dress Dance. It was only after their introduction and sharing of this dance with other North American tribes, that the Jingle Dress Dance became a powwow dance category. Yet, during the first year, jingle dress dancers were not immediately fully accepted, but 
"were to go to the end of the ladies Traditional Dance category" (2001:11).

Instead of citing from the literature of scholars, I prefer to let aboriginal women express their thoughts and feelings, to speak for themselves as Jingle Dress Dancers and participants in such ceremonies. An Ojibway from Lake of the Woods Reservation, already a jingle dress dancer, suffered from a heart condition. She was told to quit dancing because it was too strenuous, but she could not stop. She loved the dance because of its healing power. She never quit dancing. Her mother told of a traditional jingle dress gathering (which she coordinated) to which people came from the East coast to the West coast. We held it on one of our "sacred islands" with lodges and roundhouses. First the dresses and drums were feasted, then we shared the teachings of songs and dances. Our ceremonies lasted four days and four nights. We sat in roundhouses in the evenings to sing and to exchange gifts. We would dance jingle, using the side-step. The Elders too were laughing and had fun. Her grandfather told her that there had not been a gathering of this kind for 52 years (Rossina 2000:99-101).

A woman of the Poundmaker First Nation expresses her thanks to her grandfather for encouraging her to a jingle dancer's way of life and for taking part in powwows. "I am often given tobacco and asked to dance for a sick member in our community. There is a person in a wheelchair for whom I dance and pray. It's a good feeling, the healing part of it." (Meeches Video Production, n.d.).

Another Ojibway recalls how, at age 13, "I did not have a full understanding of who I was; I was struggling out there, trying to find myself, to find a place where I felt comfortable and welcomed. I knew I was native. Then I had dreams about the jingle dress. At that time I was dancing 'fancy' at powwows, though not seriously. Eventually I made my first jingle dress, brought it into my family which had a lot of problems then. I followed my recurring dreams; I would hear the cones clinging together; how beautiful 
they sounded. Eventually I started traditional powwow dancing. I like the traditional aspect of powwows, but later I joined the competition powwows. But at traditional ones, “you don't have that negativity of a gathering, no competition which can become too serious, and politics often gets in the way. The jingle dress conveys much power; it should not be part of the competition powwow because it can lose its power of healing" (interview, Oct. 2006).

Only rarely are negative powwow events conveyed. Nevertheless, at a Mille Lacs powwow, a jingle dress dancer from the US started dancing during the Grand Entry when some jingle dress dancers from Canada appeared to be "dancing something in the back of me", sending me "bad medicine". After the dance "I sat down and started hurting clear up here to my hip. Oh, it hurt". She talked to a medicine man about what happened, asking him what kind of medicine those women from Canada used. He replied that it was "snake root" and "if it had bit your heart you would have died". In the end, she believed, it was the medallion she wore, blessed by a priest, which saved her (Rossina 2000:108-109).

In March 2007 I attended an indoor winter powwow at which about a dozen Jingle Dress Dancers were present. Towards the end of the afternoon it was announced that a native five-year old boy was seriously sick in hospital, suffering from a respiratory illness. All Jingle Dress Dancers were then requested to dance for the healing of this little boy. Visitors and participant were asked to stand up and to pray while the women danced to the sound of the drum. They danced for about ten minutes. It was a very solemn and moving experience which I shall never forget. (see Figs. 22a, 22b)

In Chapter III I have closely considered the historical development and transition of the Jingle Dress Dance tradition, as well as the symbolic significance of the regalia. I have addressed the issue of women as jingle dress dancers, the part they play as healers and medicine women in their communities. Another matter in the following chapter is to 
answer such questions as to whether the Jingle Dress and Dance will undergo further changes in the foreseeable future, and whether any transformation will weaken or strengthen its continuity. 
$=$

Figure 22a

Prolonged drum beat, while the singers rehearse the song.

I $f=170$ 2) $d=175$ 4) $d=181$

Al)

ya we ya ya we ya ya we ya

2)-4)
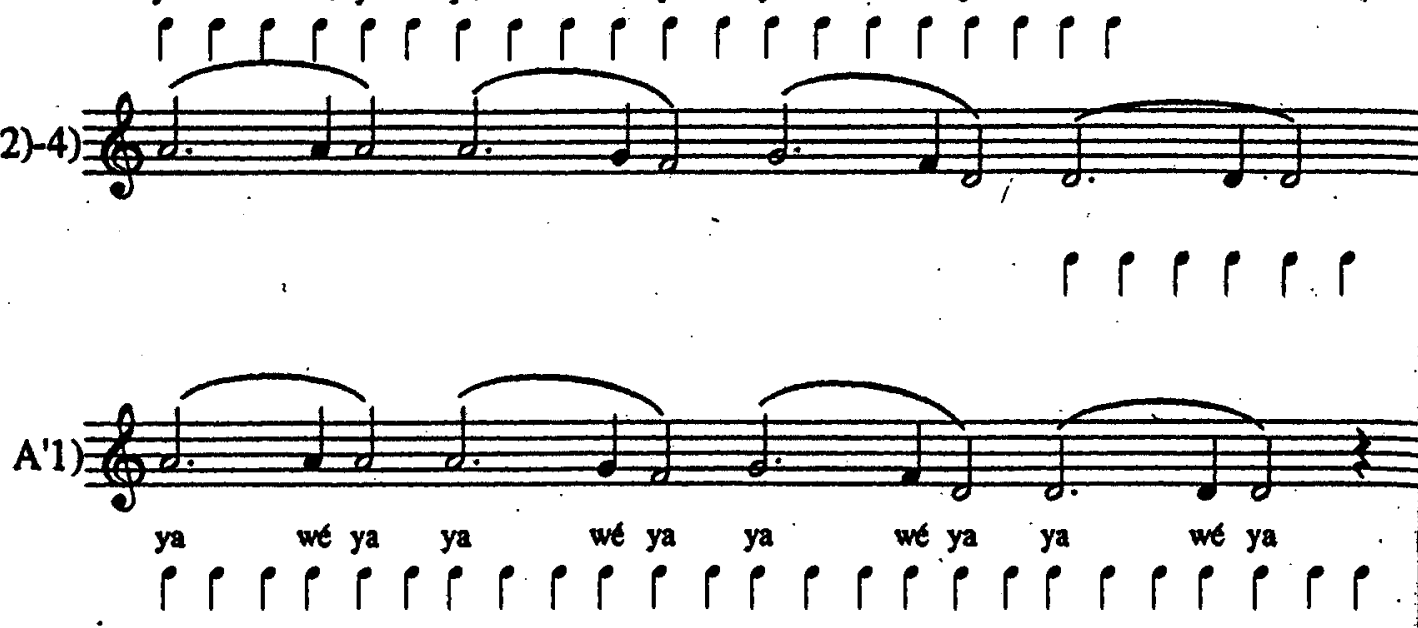

2)-4)

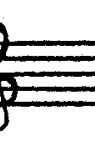

B1)

E.

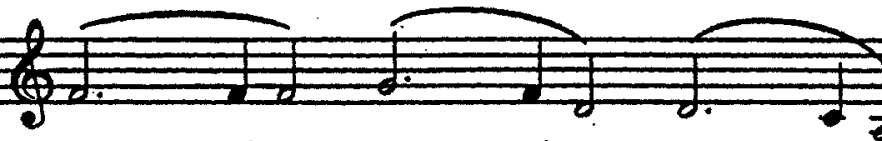

ya we ya ya we ya ya we ya

p p p p p p p p p p p p p

2)

ibid, and tendency to begin each section of the phrase after the beat

C1)

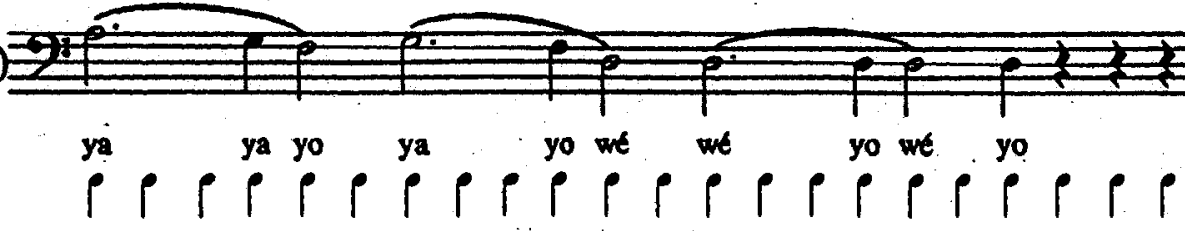

Jingle Dance Songs - Music Nates - song 18

Berbaum, s. "Ojibwa Powwow World" (Ph.D.Dissertation, 2000) 


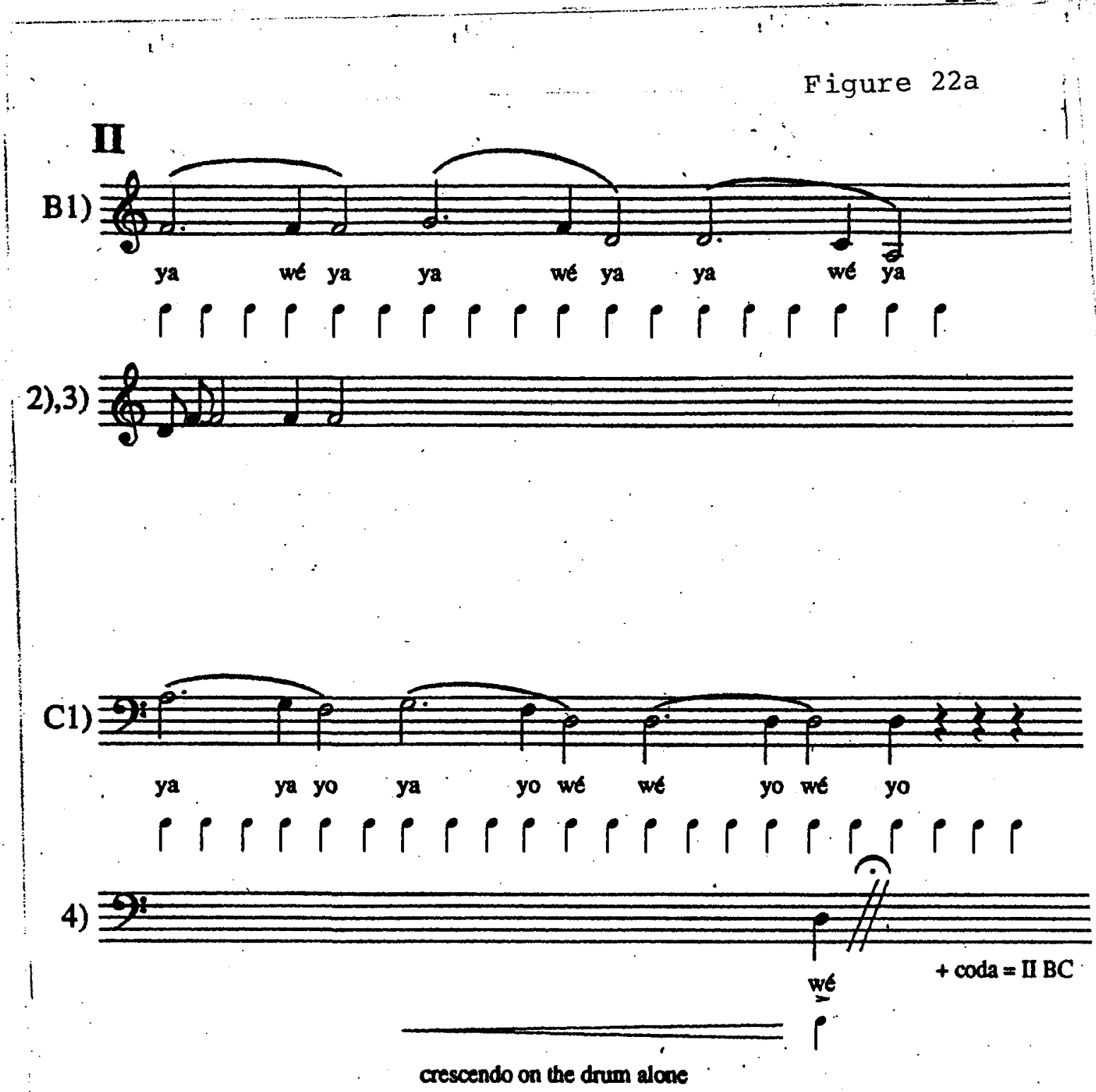

SONG 18

A. Name of the lead singer or drum group: Jo Big Georges, Big Island

B. Type of song: Jingle Dress

C. Tempo: quarter note $=170$ Acceleration

D. Form: 1. $A A^{\prime} B C-11$. BC

Coda

Number of renditions of the basic form: 4 (requested by the master of ceremonies)

E. Range: octave plus perfect fifth

F. Beat: straight

G. Other: 


\section{6 beats}

A 11

$(J=(76,2) J=190$ 4) $J=193$

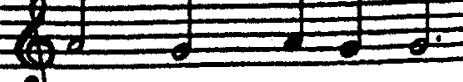

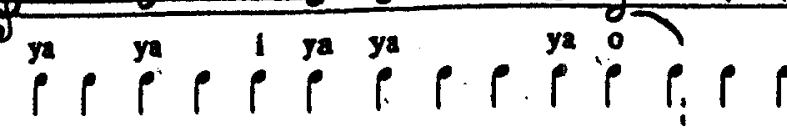

2)

(1)

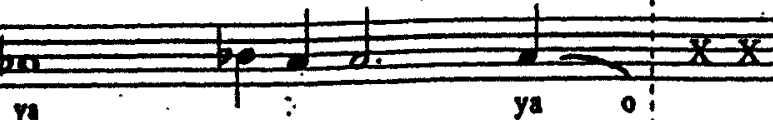

3)

.

ya 0 :

4)

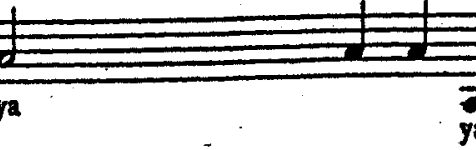

A'1)

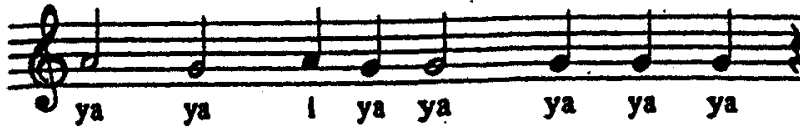

p p p $p \rho p \rho p-\rho p \rho$

2)

田

3)

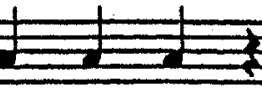

4)引

B1)
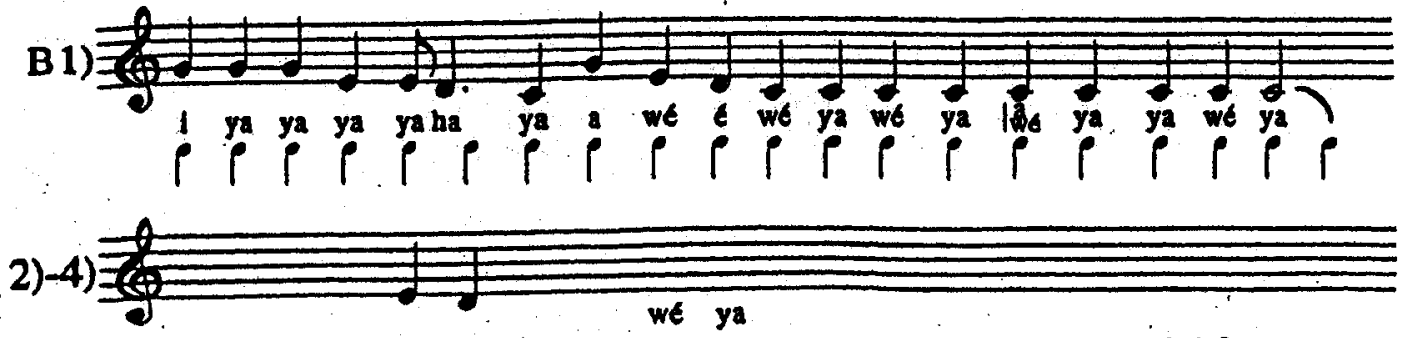

Jingle Dance Songs - Mu'ic Notes - Song 19

Berbaum,s. "Ojibwa Powwow World" (Ph.D.Dissertation, 2000) 
112

Figure $22 \mathrm{~b}$

C1).4)
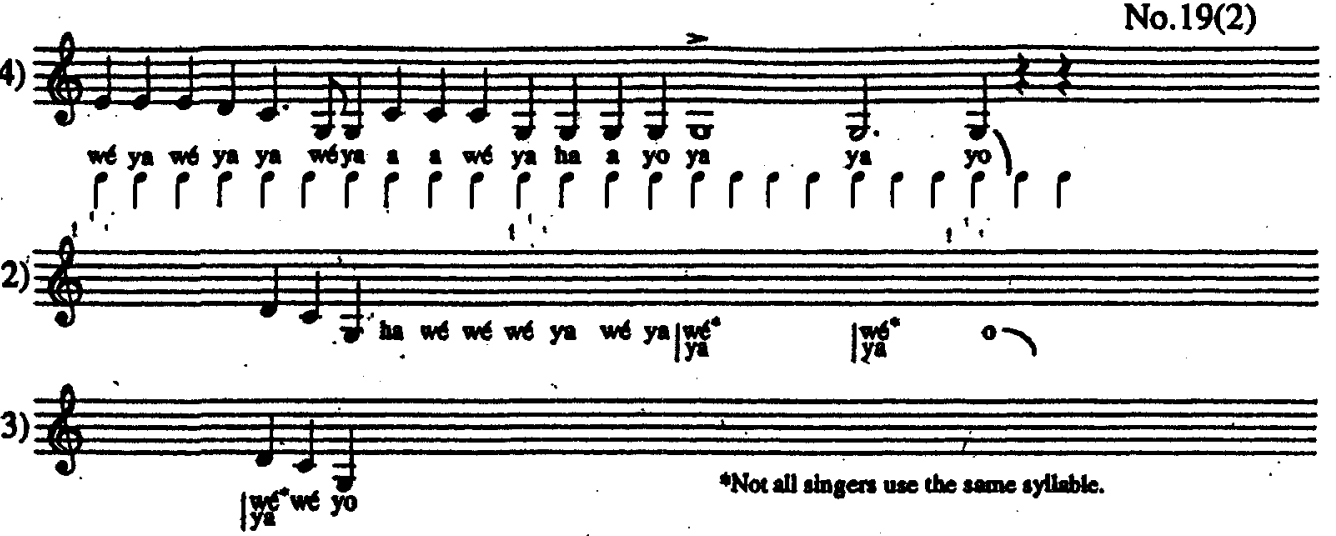

II

B'1)

we ya we ya weya ya ha we ya we ya we ya ya ya ya we-a

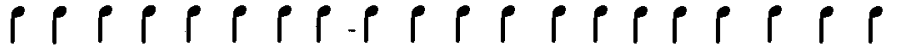

2)-4)

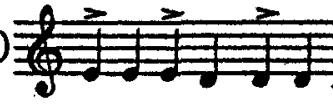

ya we ya

C'1)

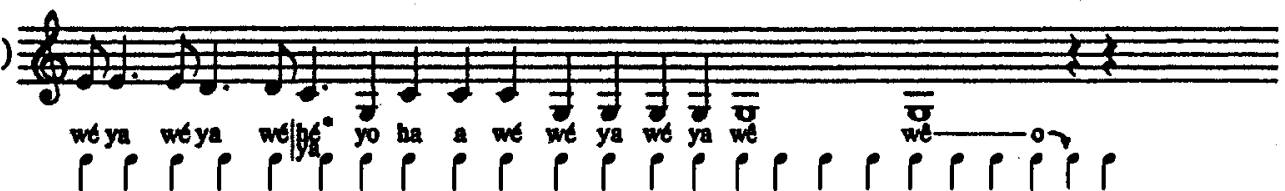

2)

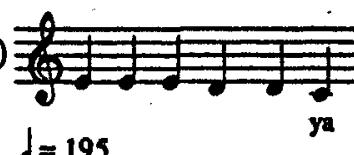

4) 195

SONG 19

A. Name of the lead singer or drum group: Shoal Lake

B. Typo of song; Fast Jingle Dross ("a roal one," the master of ceremonies commented)

C. Tempo: quarter note $-176-195$

Acceleration.

D. Form: -1. AA'BC - II. B'C

Coda

Number of renditions of the basic form: 4

E. Range: octavo plus major second

F. Beat: straight

G. Other.

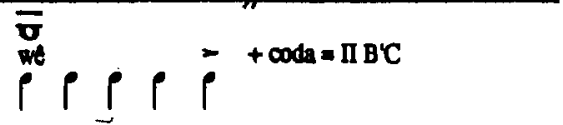




\section{CHAPTER IV}

\section{TRANSITION AND TRANSFORMATION}

The aim of the last chapter is to determine, through examination of the literature, and by listening to Aboriginals' voices, how vital a cultural force their ceremonies are and how native people imagine their future within a non-native society to evolve. Will the ongoing 'Indian urbanization' weaken or strengthen their identity?

After considering several religious and secular healing ceremonies which have survived or been transformed in eastern and western North America, I concluded that the process of healing native peoples in body, mind, and spirit will continue. Current and transforming ceremonies will give new and relevant meanings to their lives. The Jingle Dance Dress, especially in its traditional form, will remain an important fixture equally for women and men.

\section{Change and Continuity - Is Transformation Desirable?}

Cultural and social changes have taken place in the lives of all North American Indians over the past centuries. Their adaptability and flexibility guaranteed their survival in a Euro-American-Canadian world. In Dubin's words, they have become "truly bicultural" and are thriving in the richness of two traditions (1999:39). Although some native Indians may appreciate many of the traditions of non-natives, Dubin does not refer to non-native culture as the dominant one which has not only undermined, but almost obliterated Indian culture, and with it severely shattered the peoples' identity. One could say that the $20^{\text {th }}$ century provided them with the opportunities to eventually regain their 'Indianness" and to revive cultural traditions such as ceremonialism.

The old 'Indian Self', therefore, had to emerge into a new Indian Self, with a reborn, renaissance Indian identity. Ames (in quoting Berger) states that native peoples' 
"insist that their culture is still to be the vital force in their lives; the one fixed point in a changing world is their identity as Natives" (1992:77). A member of the Winnebago tribe spoke to future generations when he pronounced that, should he come back in a hundred years, he wants to see his tribe looking Indian, with brown, bronze skin, his people to speak their own language, singing their own songs and practicing some of their own beliefs (Kohn and Lynwood Montell 1997:209). Regaining lost identity is crucial to native Indians, as individuals and as member of their tribes, communities, and Nations. Citing Coates (in Behiels 1999:23), they "face a crisis of identity as they seek to navigate the troubled waters between indigenous culture and the values and assumptions of the dominant society". In the past 25 years, however, through a "resurgence of aboriginal confidence and determination", Indians were able to gain some economic, social and political power. Such resurgence encouraged greater identification with their culture (1999:23), a resurgence that is also to be understood as a healing process.

How were Aboriginals going to accomplish their rebirth? Which were some of the social, religious, and political steps that needed to be taken? To reach at least a moderate understanding of this process one needs to examine such cultural-social and political aspects as the shift in the Indian Act, the Potlatch, the Sun Dance and the Ghost Dance, as well as one of the prophetic movements such as the Indian Shaker Church. Indians in Canada still enjoyed a fair amount of autonomy before the Indian Act was passed in 1860. Once passed, a transfer of full control and power to the Canadian government took place and changed the nature of Native and White relations (Steckley and Cummins 2001:120). The Indian Act altered the lives of Natives in many aspects since its overall goal was the restriction of freedom in the name of total assimilation into western culture and lifestyles. In this thesis, however, we are only concerned with ceremonialism. The Canadian and US governments were fully aware of the significance of Indians' religious and spiritual expressions, their observance of rituals, sacred and temporal dancing and 
singing, which were performed at all seasons. They were regarded as the major barrier to assimilation. Although Indians all across Canada were affected by the implementation of the Indian Act, the West Coast natives were first to experience the impact of this law. In April 1884, the anti-Potlatch law, as amendment to the Indian Act, was introduced, banning this 'give away' ceremony. For centuries, the potlatch ceremony had marked important occasions of the Kwakwa ka'wakw First Nations' and all other North Pacific Coast peoples'. This ceremony of gift-giving and receiving also included the naming of children, marriage, the transfer of rights and privileges, and the mourning of the dead. Missionaries such as William Duncan began the battle against Indian religions in the $1850 \mathrm{~s}$, describing potlatches as barbaric. This view strongly influenced the Canadian government. Due to its gift-giving and gift-receiving character, it was also viewed as 'communist' and therefore against the "principle of private property" which governments tried to instill in native people (Valaskakis 2005:164; Steckley and Cummins 2001:121). Cole and Chaikin believe that this law was enforced "to persecute native people, not to prosecute for offences" (1990:1).

What is clear, however, was the enormous gulf between Whites and Northwest Coast Indians in their understanding of wealth and possession and, ultimately, what to do with it. For both societies, wealth was associated with prestige. But this is where the similarities ended. Western societies believe in accumulating wealth and possession, while Northwest Coast societies believe in the distribution of wealth, even in its destruction, as the only justification for gathering wealth. To give it away meant "to confirm or enhance prestige and satisfy pride". Rank, privileges, names and crests awarded the giver with prestige and rank which were fundamental to Northwest Coast social systems. The potlatch, accompanied by songs and dances, sustained these and other religious ceremonies (Cole and Chaikin 1990:11-12; Valaskakis 2005:164). On the other hand, the authors go on to explain that the potlatch, linked to social stratification, was 
more than an extravagant ceremony, it was "fundamental to class and privilege, even to economic and social exploitation. The guiding themes of social organization were a hereditary transmission of status and privilege. Marriages were arranged in accordance with the system of rank" and ultimately defined the social status of the offspring (1990:12). Unlike other differences between European and native conceptions (i.e. the use or exploitation of land), Europeans should have been expected to understand, even empathize with this factor of the potlatch, providing they were aware of it at that time.

Prior to the amendment of the Indian Act, various official observers of Pacific Coast Indians forwarded their comments and opinions to the federal Canadian government: Potlatches "retarded civilizing influences and encouraged idleness among the less worthy Indians", that "Feasting and giving away property took up too much time", interfering with more industrious pursuits". Another advisor, Gilbert M. Sproat, commented to the government that this "giant evil ... has to be met and overcome". In his opinion, the potlatch was "the parent of numerous vices which eat out the heart of the people", producing thriftlessness, forcing women into prostitution; Indians will not acquire property or become industrious "while under the influence of this mania". He insisted that the potlatch produced poverty and "a habit of roaming about"; no material progress was possible while this ceremony existed. He advised the government to "lay an iron hand upon the shoulders of the people" to eradicate this evil. His recommendations were accepted by Ottawa, while a royal proclamation stated that "the Queen desires her Indian people to abandon the custom" (Cole and Chaikin 1990:20, 14-15, 18). These comments are meant to stress the severity of officials' judgements, and proof the ignorance and prejudices pervading at that time.

Outlawing the potlatch ceremony was another step in the cultural genocide against native people in Canada (and the USA). Equally destructive to their culture, and ultimately to their identity, was the suppression of other traditional dances such as the 
Ghost Dance and the Sun Dance. Like many other dance ceremonies, the Ghost Dance emerged through a prophetic vision. For most Indians of the American Northwest it was a time of economic, political and cultural devastation. Smoak explains that the Ghost Dance movement (begun in 1870) was an "appeal to spiritual power to overturn a world that was not of their making". Ghost dancing became a metaphor for a peoples' attempt "to recover the unrecoverable". The anthropologist James Mooney, in his 1896 report to the Bureau of American Ethnology (BAE), emphasized that the cultural deprivation experienced by Indians caused the rise of the Ghost Dance and other socio-religious movements. However, the BAE showed no understanding for Mooney's "cultural relativism" (2006:199, 2).

Not surprisingly, a number of prominent native prophets emerged across North America who tried to find an indigenous way of dealing with this legally-sanctioned culture-genocide. One such prophet was Handsome Lake who experienced his visions in early 1800 . He told his people, the Lakota, of the necessity and urgency of a religious reformation and the continuation of certain spiritual practices. The Creator has sanctioned thanksgiving festivities to take place in his honour. The people should go to the dancing ceremonies with washed and painted faces. The Creator's teachings must be obeyed. For their individual and community's salvation, his people must repent, must avoid hell and a fiery end of the world. Thus, Handsome Lake's teachings were more reminiscent of Christian belief than of the traditional Iroquois belief in 'Gaiwiia' (Cave 2006:199-200).

What then was the reason for the prophet's new, reformed kind of religious teaching? While Christianity taught of a Great Spirit who watched over every individual, listed their sins, and executed final judgement after death, Indian religious practices were "about empowerment, not forgiveness". Cave explains that this was not a matter of acculturation such as the displacement of native values and beliefs, but that of the colonial power. The partial answer lies "in the particular uses made of the concepts of sin, 
guilt, and punishment of sin by the prophet's teachings". This belief in heavenly judgement and punishment in this and the next world, provided a vehicle to regain power and control over their present and future lives. Prophets such as Handsome Lake dreamed and thought of rebirth. To believe in world renewal and rebirth was at the core of native peoples' ritual life (2006:244-245).

The prophesies of other prophets such as Wovoka (Paiute), and Tenskwatawa (Shawnee), combined with the Eastern Woodland myth of the Earth Diver, gave rise to several religious movements of a syncretic nature. The people were taught the sacred Ghost Dance, to be performed at regular intervals. The dances expressed "a continued vision of how to resist colonization" and "how to release all the spirits contained in the old ceremonies and rites". The dancing would generate a new vision of Indian renewal, of restoring "traditional consciousness and order" (Battiste 200:57-58). On another level, the Ghost Dances had the function of "restoring the flow of power toward native people", and to be a means to express social identities. Especially after the massacre at Wounded Knee (Dec. 1890), the Ghost Dance played a significant role in identity formation. Eurocentric writers entirely misunderstood the visions of the Ghost Dance (Smoak 2006:3; Battiste 2000:57).

In a similar vein to regain collective power and identity was the vision of Neolin, possibly the most outstanding prophet of the Eastern Woodlands. Newline, (a Delaware belonging to the Algonkians) and his people were, at the time of his vision in the early 1760 s, refugees in the West, trying to forge a new identity for themselves. Cave (2006:2227) describes his visionary "journey to heaven" to meet the "Creator of the Universe". After some trials and tribulations, he met the Creator "who was displeased with his Indian children". They were suffering because their land, which the Creator had made for them, was occupied by the European intruders. The Creator denounced the Delawares' behavior and urged them "to become good again", then they will receive what they need; they 
"must resist further European incursions", pray to him and abandon any belief in other deities. When Newline returned to his people, he taught them to keep the commandments of the Creator, so that the happy life they once knew would be restored to them. A reformation in their religious practices was vital, and these included rituals and ceremonies which Eastern Woodlands had always believed to be gifts from benevolent forces.

The vision Newline had received and passed on to the Delaware included numerous new ritual practices, although satanic rituals were denounced. They reflected a native, not Euro-American "understanding of the relationship of human beings and spiritual forces". Objects such as prayer sticks, on which prayers were carved, had to be used daily by his followers (Cave 2006:37). Although the Creator gave him precise instructions as to the way in which his people had to pray, none were forwarded about the type of dances to be performed. Yet, like with other revelations, the foremost objective of a spiritual quest was to acquire or regain power, to be achieved primarily through the restoration of traditional ceremonies. It was clear that ceremonial continuity remained at the core of Indian survival and identity.

Another Indian ceremony which government officials and missionaries felt needed to be suppressed or outlawed was the Sun Dance, mainly performed by tribes of the Great Plains such as the Dakota, Kiowa, Cheyenne, and Blackfeet. Those 'outsiders' who were granted the privilege to witness this dance found it the most "repugnant" of all native dances. As in the case with other dances and rituals, these officials also misinterpreted the function and meaning of the Sun Dance, viewing it "as an immoral and seditious act", a ceremony of self-mutilation and self-torture, "repugnant to common decency" and deemed as an impediment to civilizing the Indian people (Holm 2005:34).

The Sun Dance is a highly demanding ceremony, requiring several months of preparation and days of hard, physical labor. This is followed by four days of absolute 
fasting. The dancing lasts from dawn to dusk, often under a blazing sun, in a confined sacred center. The final offering is 'the flesh of one's chest to be skewered and tied to a tree until dancing tears the skewers from the skin". It is "a religious act of self-abuse", freely chosen by the participants. On the fourth day, the dancers leave the center with great sadness, saying a prayer to the tree that gave its life to this ceremony, and committing themselves to return the following year (Tinker 2005:55).

What were the reasons for the Sun Dance ceremony? Although there could have been a variety of individual reasons for taking part in the dance, the primary communal reason, as Tinker puts it, is "That the people may live! The well-being of the whole community depends on the spiritual work of a few who have made the commitment on behalf of the whole" (2005:56). The sacrifice made by these men who were either fulfilling a vow or had received a divine vision, "symbolized the humility of humankind before the Great Mysteries of the world". As already mentioned, they danced for four days to the point of exhaustion as a sacrifice for the tribe's continued health and prosperity, thereby serving religious, social and political functions. The Sun Dance, which had different names among other Prairie tribes (i.e. Thirsting Dance, Medicine Lodge, Making a Home) and was not always a blood sacrifice, was a ceremony of renewal. It was not a war dance (Holm 2005:34-35).

In the USA, religious laws extended to all Indian religious activities, not only to the Ghost Dance and the Sun Dance. The Ghost Dance was banned in 1883 and, despite modifications to the ceremony by such tribes as the Cheyenne in Montana, an even stricter ban came into force in 1897. In Canada, ceremonial activities were outlawed in 1884 by the Indian Act and several of its amendments (Valaskakis 2005:166; Holm 2005:35; Pettipas 1994:88). In the case of the Ghost Dance, other dances and the potlatch, natives continued to perform their ceremonies, with some modification, in secret, out of earshot of reservation officials. Secrecy and deception helped to protect this 
vital part of Indian culture. It is important to note that dances which were not viewed as warlike by government authorities, were enforced less strictly. In some instances, Natives (i.e. the Cheyenne) invited Whites to their campgrounds to witness their dances by giving them the appearance of "social, festival-like functions" by including parades, but omitting certain elements from their dances (Holm 2005:37).

While US government officials and white farmers remained convinced that Indian culture was doomed to extinction, federal and provincial government agents in Canada experienced great difficulties in enforcing the ceremonial ban. This was due not only through a lack of manpower and resources, but also because travelling to remote native communities along rugged coastlines and into the remote hinterland proved difficult. Eventually, these bans were re-evaluated, then lifted altogether, in the USA in 1907, while in Canada this part of the Indian ct was not revised and the law not abolished until 1951 (Holm 2005:37, 35; Pettipas 1994:93-94; Valaskakis 2005:164-165). Despite these oppressive laws, the essence of ceremonial culture of Indians across North America, from west to east, had endured.

Aboriginal knowledge, spiritual understanding, ceremonialism, and peoplehood were being preserved by all native Indians during the period of the bans. They sought "to maintain their relationship with their spirit world" through adaptation, secrecy, deception, and syncretism. At the same time, they tried to appease the Whites (Holm 2005:33, 40). On the matter of syncretism, I think it is essential to take a closer look at the Indian Shaker Church. The founding and continued success of this church can be understood as a prime example of the way in which aboriginal (in this case North Pacific Coast) tribes used some of their traditional beliefs, ceremonies and symbols as a vehicle to combine those with newly acquainted belief systems. Old traditional symbols which had become powerless during the $1800 \mathrm{~s}$, were being 'regenerated' in a combination with Christian ones in order to reclaim their lost power and regain Indian identity as spiritual people. 
Several syncretic movements were established throughout the late 1800 s and early 1900 s, such as Peyotism and Shakerism. As with the potlatch, the Sun Dance and the Ghost Dance, the syncretistic nature of those movements provided Indians with another attempt to regain and preserve a ceremonious relationship with their spirit world. With this in mind, it is worth examining the Indian Shaker Church in more depth.

In 1881, a Salish (Puget Sound) Indian called John Slocum, died, but was "miraculously revived", bearing a message from God and his angels for all Indians. They were to abstain from smoking, drinking and gambling, and reject the old shamans in order to attain salvation. A church was built on Squaxin Island. Slocum preached his message, but his followers soon left him. He became ill again and appeared to be dying. A shaman was consulted, which angered his wife Mary. She had believed in her husband's vision. She began to pray, then to shake uncontrollably. As her shaking intensified, her husband recovered. This was evidence of God's medicine to the community. During Slocum's first meeting in his church (summer 1883), while presenting his message, "many were possessed and healed by the "shake". He founded the Shaker Church, developing unique rituals, with a philosophy and ideology of his own. It spread all over Washington State, Oregon, northern California, and coastal British Columbia. Most of its members are Indian, although membership is open to everyone. The church grew rapidly, especially among such tribes as the Skokomish and Squaxin (Amoss in Ethnohistory 1978).

Apart from the healing aspect itself, what other factors contributed to the success of this religious movement? Similar to other revitalization movements of western and eastern North American Indians, the Shakers, as Holm pointed out, wanted to be Christians, while also remaining Indians. Slocum wanted to infuse some Christian ideals into native belief systems as a form of healing, to curb such problems as alcoholism, from which Slocum himself suffered. This church's adaptability to catholic and protestant practices appealed to many Natives. At the same time, it maintained various important 
tribal customs. Because of its "doctrine of temperance", white officials allowed the Shaker Church a fair degree of leeway in its practices and rituals. One observer remarked in 1910, that the church was "based on Christianity and intermixed with heathenism". A significant factor in Shakerism is its continued practice of the potlatch ceremony which was meant to attract the more conservative members of their tribes (2005:41-42). Amoss, however, who had studied the Shaker Church thoroughly, never mentioned the potlatch ceremony.

Shaker rituals were influenced by the Catholic Church's use of candles, the ringing of hand-held bells, the sign of the cross, and the protestant way of public confession (anon.[d], 2008). Contrary to Holm, the above website article refers to the strong opposition from non-natives, and their fear of a possible Indian uprising. Despite all those discrepancies by scholars, Shaker practices were banned by law in the same way as the Ghost Dance. Holm (in citing Powell) writes that, during that time, Shakers were permitted to hold meetings only under strict regulations, i.e. 'shaking' was allowed only on specific days such as Sundays and Wednesdays. Many members who had not adhered to those rules, were imprisoned. The Shaker Church's other goal was to unite all native Indians, "regardless of tribal affiliation, under the banner of religious belief". The church succeeded, spreading rapidly and growing strong throughout the $20^{\text {th }}$ century $(2005: 42)$. When considering the rules and rituals originally laid down by the church officials, it becomes clear that 'empowerment' for North Pacific Coast tribes was foremost on their minds, and this empowerment should ultimately unite their tribes. The adaptation and syncretism served as a vehicle towards gaining more freedom from dominant whites and imperialism.

The Indian Shaker Church of Washington Records (1978) cite the significance of obeying the rules, including that of the garments to be worn to the service, the power of 
trembling fingers and quivering body, the power of dancing, singing and the ringing of bells, and the power of true faith. "Those with unclean thoughts will lack power." Most significant among the objects of the newly-founded church was "The elevation of the Indian female to be equal in government of the church", as well as the rule that the Deacons in each church can be male or female (anon.[e], 1978). Amoss provides us with one of the most comprehensive accounts of the Shaker Church, in particular about the symbolic system the church developed and which greatly explained its early success and persistence. The author states that "A primary task of any religion is to make sense out of a particular way of life set in a particular environment. People need to feel good and content about it, and ritual symbols "operate as a bridge" between a religion's explanatory and emotional functions (in Ethnohistory 1978).

As well, the traditional social system had been disrupted in the late 1800 s among the North Pacific Coast tribes (i.e. the Salish). An alien political and economic system was imposed on them, undermining native beliefs and rituals. This brought on "a crisis of meaning". Therefore, a new system needed to be developed which would "make sense out of their new circumstance", one that would offer Indian people an explanation and a solution. The Shaker Church found the solution by syncretizing some of the old religious traditions with the alien religious ideology, and re-presenting the new church as coming directly from God. The supernatural aspect, therefore, and its introduction of sacred symbols (old and new), gave the Shaker Church the necessary legitimacy. How crucial was the introduction and integration of ritual symbols to the Shaker movement's success (from late 1800 to late 1900)? Amoss explains that Indians in the movement have parallel symbolic systems and parallel solutions to the problems of sickness, sorrow, and suffering. For instance, their "revived aboriginal style winter dancing complex" brought 
them together in solidarity, stressing a spiritual heritage they still see as superior not only to other religious groups, but especially to that of white people (in Ethnohistory 1978:225-247).

As pointed out before, the new-found Indian Shaker Church "transcended both old and new", although at that time it was only one of several movements which developed a new ideology and new rituals to overcome the Indian "crisis of meaning". Why did Slocum's (and his wife's) movement succeed, while other local prophets failed? The answer, in great part, lies in the curing power of the "strangely contagious" shake which his followers soon experienced too, as well as the Shaker rituals and symbols (Amoss in Ethnohistory 1978). Indian parents were eager to baptize their children in the Christian way since it was regarded as a powerful ritual, symbolizing either the gaining or regaining of health for their children (Barnett 1957:344). Of great significance here is the Christian cross which, originally, has no native precedent. It surmounts the belfry of the church and is placed in the center of the altar setting, as well as on prayer tables in people's homes, in Shaker cemeteries and on head stones. However, crosses are not worn as ornaments. Of even greater importance than crosses is the use of candles. From the beginning, they were used whenever there was an attempt to cure the sick, and during church service (instead of gasoline lamps or electric light). Slocum named candle light "the light of heaven", others called it "the holy light" or "the purity of light". Shaker candles and fire symbolize supernatural power, signifying strength and purity. They are also used to cleanse sick people "by passing the candle flame lightly over the sufferer's body". Interestingly, the new spirit dancers' headdresses were held over the fire before wearing them for the first time. The Indians rationalized that the "holy flame" of the candles "dissipates sin and sickness or forms a protection against them, and that a lost 
soul gets cold and may also have been subjected to evil influences" (Barnett 1957:204205, 207; Amoss in Ethnohistory 1978).

Another ritual object the Shakers apply during ceremonies and which had been part of native tradition for millennia are bells. Their new usage, however, was adopted from Christian churches for the Shakers' own purposes. Amoss explains that 'as the drum was the audible symbol for the traditional spirit dancing so the ringing bells signified the Shaker gatherings", creating the rhythm to which people moved. As drums were and are used to mobilize supernatural power, so did bells summon the faithful, announce the beginning and end of the service, the blessing at meal-time, and the healing ceremony (in Ethnohistory 1978). Traditionally, bells had been worn on garments, bags, and on ceremonial objects used by shamans. As mentioned previously, it can be hypothesized that metal jingles were substituted for bells on the Jingle Dress in the late 1800s, early 1900s. Barnett describes the Shakers' bells as the least suitable feature of their ceremonies. The bells are made of brass with a wooden handle, one held in each hand. During the various rituals, including curing rites, they are rung loudly and continuously by men or young boys. Women do not ring them. While ringing the bells in front of them, the men stamp their heels in rhythm with the bells until, after about an hour, "the noise rises to a deafening crescendo". Yet, no mystical attribute can be attached to those bells (1957:209).

Shaker songs or hymns illustrate another "process of symbolic substitution". They are believed to be gifts from the Holy Spirit, received by individuals, but sung by the whole community. The songs are perceived as a substitute for aboriginal power songs, except that the spirit dancer would have sung and danced alone while other people drummed for him. The Spirit Dancing ritual emphasized individualism, the Shaker ritual 
solidarity and togetherness. Just as they shake together, they also sing together (Amoss in Ethnohistory 1978).

The last but not least of Shaker features that needs to be emphasized is the Shaker garment. John Slocum would wear a long, white shirt during church services, either collarless or with an open collar and worn loose outside his trousers, reaching down to his hips. Another description is that of a white tunic similar to a Catholic priest's alb or the type of white tunic as one missionary gave to children in his choir. Church male-members soon adopted long, loose robes of pure white, decorated with blue crosses, to be worn during Sunday services and healing rituals. Mary Slocum by then experienced another revelation which induced her to "teach" that women have to wear white dresses with blue ribbon belts and collars, covering the neck (while men's shirts are to be collarless with wide sleeves). The colour white signified to Shakers purity and protection from evil. The Shaker colours of blue and white contrasted with the aboriginal colours of red, white, black. Unlike the Spirit Dancers' outfits, the Shakers' were always made of European style and fabrics. Yet, white also stood for protection or healing in aboriginal tradition (it was used as face paint). It appears obvious that such colour symbols carried over into the Shaker movement. In aboriginal and Shaker tradition, "individual revelations" were of great importance, therefore variations in clothing were tolerated by both (Barnett 1957:214; Amoss in Ethnohistory 1978).

A strong correlation can be made between Mary Slocum's revelations about ceremonial garments and those of Maggie White and the jingle dress. Does it again illustrate a process of symbolic substitution or is it merely a process of cultural transformation? As a last comment on the Shaker Church it needs to be pointed out that Indian people borrowed some Christian symbols "to create a system which was relevant 
to their own cognitive style". Many Christian symbols were not borrowed. The whole "eucharistic complex" was absent, as well as baptism, individual confession, and marriage rites. Church officers and ministers are not formally sanctioned or consecrated. Most striking of all was the rejection of the Bible during church rituals. This caused a schism in the Shaker Church which begun in the 1930s. To the church followers, the 'act of shaking', the trembling, remains the most distinctive feature as it signifies the power oft the Holy Spirit and promotes the healing of the sick (Amoss 1978; Barnett 1957:133134, 243).

I will now address the situation of the contemporary Shaker Church of the Salish Indians, only to point out that by the late $20^{\text {th }}$ century it was still flourishing, still syncretizing the old native religion with varieties of Christianity. The modern Shaker Church, with its symbols and rituals co-exist not only with Protestant and Catholic churches, but also with the Pentecostal church, aboriginal-style Winter Dancing and Spirit Dancing -- a form of shamanism. Numerous transformations have taken place over the past decades, but contemporary Indians maintain their ancestral heritage as, in quoting Amoss (1978), "their heritage of successful response to the attempted cultural domination during the period of contact, as represented by the Shaker Church". Both heritages are important parts of their Indian identity.

Although the Shaker Church became a crucial transformative and syncretic movement among North Pacific Coast tribes, other revitalization movements deserve a brief mention. The new theology of liberation and healing, the new dreaming, as Tinker refers to $(2005: 2,4)$, has taken on different forms. Its 'political process and reality' will be discussed later. Like Shakerism, Peyotism became a new and adoptive religion during the same period among the natives of the Great Plains. With its same intention of uniting 
the people "under the banner of religious belief", it spread quickly and has remained strong throughout the $20^{\text {th }}$ century. The peyote plant (or peyote button, as it is also called) has been used by the Cora people of Mexico since the mid-17th century "as a sacrament and medicine". By the 1870 s, American tribes such as the Comanches, Iowa, and Apache, had turned the peyote medicine ritual into a ceremonial sacrament. The people, as in other religious movements, sought to obtain a spiritual connection with the Creator. The peyote religion's pan-Indian theme not only accommodated tribal customs, but a few Christian practices as well, although variations existed among different tribes. The peyotists' philosophies were similar to Christian ones, although the doctrine of original sin was absent, as it was from most native religions. In order to obtain a vision, worshipers ingested peyote with the aim of "finding peace with the supernatural or to seek solutions to personal problems ... or to obtain spiritual power from a supernatural being”. Unlike in the Shaker Church, the peyote ceremonial objects used were more of an aboriginal nature, i.e. water drums, bone whistles, bird tail feather-fans, cedar incense, and gourd rattles (Holm 2005:43-44). Regardless of the extent to which peyotism had become part of native people's lives, their respect for ceremonies, their belief that the world is to be viewed as a living entity, would make it impossible to conceive societies in "mechanical terms". Some ethnologists of that time, especially Franz Boas, realized "that culture determined behavior and, consequently, that cultures were self-perpetuating" (Holm 2005:44).

The last of the prominent syncretic- and healing ceremonies which deserves mention is that of the Shaking Tent, practiced by the Central- and Eastern Woodland Indians, especially among the northern Algonkian people. It also spread to the Plains Indians and as far north as Labrador. Whether the Shaking Tent tradition begun in Eastern 
North America and moved west, or vise versa, scholars are not in agreement. Schaeffer, however, asserts that it is "one of the most widely distributed religious observances of native North America" (1969:3).

Similar to the previous revitalization movements I have addressed, the Jingle Dress Dance's only links to the Shaking Tent ceremony is its healing factor, as well as some drumming, in this case, however, performed by the "conjurer" (or shaman) and his assistant, while women have in later times, as observed by Schaeffer, "largely superseded men as mediums" (1969:17). Whether the Jingle Dress Dance can or should be regarded as part of the revitalization movement, I shall discuss in the next section.

Before the conjurer or medicine man could perform his rite, a tent or lodge had to be erected. Many European explorers, missionaries and traders during the 1700s and 1800 s were able to observe the building of such tents and at times even witness the ceremony, or part of it, themselves. The fur trader George Nelson observed and recorded Cree and Ojibway conjuring ceremonies from the very early- to the mid-1800s. He described the tent or lodge to be constructed of 4 or 8 poles, each about 8 feet long, implanted vertically into the ground, enclosing an area of 3 feet in diameter. These poles were then secured horizontally by 3-4 flexible hoops, and the whole structure covered with either birchbark sheets, canvas or animal hides. Usually, the tent, which could be dome- or cone-shaped, or circular as in the case of the Woodland Saulteau (Schaeffer 1969:10) had to be erected away from human habitation, since a settlement was regarded as "dirty" and the bush as "clean" among the northern Algonkians. For the conjuring performance, the audience would gather by the tent at sunset, drumming and singing. The traditional binding of the shaman's body with ropes took place. During the shaking of the tent, he would then free himself of his rope-confinement and, with the knots still 
tied, toss it out to the audience who continued to sing and drum. With the shaman also drumming, singing or rattling inside the tent, the structure would shake from side to side to summon those spiritual beings and signal their arrival. They then "spoke" with the diviner and the outside audience, answering their questions (Brown, Brightman 1988:3, $146-147,150)$. The vehement shaking and rocking of the tent could last ten or more minutes, at times lifting off the ground, while the conjurer would speak "in unknown jargon" until he announced that the spirit(s) had favoured him with the answers he had requested (Schaeffer 1969:4, 6).

What were, or possibly still are, the purposes of the Shaking Tent ceremony and religion? Nelson identified the wish to prophesy, but other objectives were "to obtain information about persons or events distant in space or time or otherwise inaccessible to the diviners", but most typical in calling on the spirits involved the diagnosis and treatment of sickness, the location of animals to hunt, or of lost articles, as well as the welfare of missing relatives. The shaman's "medical technique" involved questioning the spirits and receiving information about the illness, its treatment, and possibly misdeeds committed by the sufferer. Besides providing information, the spirits were also expected "to take practical action on behalf of their human dependents". Nelson, however, did not discuss connections between conjuring and medical treatment or healing. Yet, he had no doubt that most conjurers felt empowered through the dreams and visions they experienced (Brown, Brightman 1988:147-149). A number of cures had been reported, such as the one by Cooper (Schaeffer 1969:16) in which a very ill Indian woman who had been given up by white doctors, was cured by a Blackfoot shaman's Shaking Tent ritual. Nelson had witnessed many such ceremonies, but was himself skeptical about them. He could not fully place the "shaking lodge intelligibly within Christian cosmology" and 
regarded conjuring as "inconsistent with Christian theology". Algonkian Indians, however, equated benevolent as well as terrible or demonic spirits with Christian angels and the scriptural devil, thereby seeking "to coordinate indigenous and introduced religious systems” (Brown, Brightman 1988:156, 158).

Due to its widespread use among Woodland- and Plateau Indians, it seems appropriate to include the Shaking Tent religion and ceremony in my discussion. It has to be regarded and understood as another segment of the revitalization movement. It was observed by explorers since the early $17^{\text {th }}$ century and (apparently) spread westwards to many other tribes which adopted the basic traits of the shaking lodge tradition. However, some questions remain unanswered. Did the practice continue from the 1950s onward? If so, which tribes and in which areas are they taking place, and have they undergone any transformation? The Shaking Tent religion necessitates further research. The scant literature (and Internet information) on the subject does not mention whether the Shaking Tent ceremony had also been legally banned or whether it simply 'went underground' at the time other ceremonies were outlawed. This religion was certainly still practiced in the 1950 s, by which time the ceremony had adapted to modern communication systems. Brown and Brightman explain that the tent, with or without the conjurer inside "was understood to channel remote sounds and voices". Decades later, when Manitoba Cree had become familiar with radios, television, and telephones, "the sounds of animals travelling through the bush" would emanate from inside the shaking tent (1988:151). In conclusion, the answer to the question, "is cultural transformation desirable?", has to be in the affirmative. It is not only desirable, but in the interest of native Indians' survival and an assured and better future. Such transformation is also a sign of vitality and persistence of cultural forms, albeit in newer versions. Tradition itself is remade 
according to cultural impulses which seek other forms. Those ceremonies just examined are only a few among many religious ceremonies which underwent some form of transformation over the past 100-150 years. The Jingle Dress Dance, despite its relatively young history, must be regarded as one of them. It not only became a vital tradition among healing rites, but also an empowering mythology for Indian women, a topic that will be discussed further in the next section.

Prophets, shamans, healers, all once possessed the sacred powers which sustained the lives of people in their communities. Cave emphasizes that, traditionally, material property for North American Indians depended not only on human effort, but "on the favour and support of the spirit beings who sustained communal life". Collectively and individually, rituals and spiritual quests were essential to their survival, and sacred power was attained through proper rituals. Missionary John Heckewelder learned of the prophet Pontiac's demand that the people return to their "former happy state" in which they lived before these strange Europeans came to disturb us, and that a reformation of their religious practices was essential (2006:xiii, 26). Although such Christian ideas about god, the devil, heaven and hell, had virtually no counterparts in traditional Indian beliefs, these prophets skillfully "incorporated such borrowed concepts within a nativist framework". Only by tapping "all of the ambiguous power" of enduring symbols, myths and rituals, by blending elements that drew on "age-old patterns", as well as those that were clearly innovative, could native revitalization movements (and syncretic religions) actually succeed and gain wide acceptance. Again, the author stresses that such movements usually originate in one or several visions of individuals and "are the result of severe social dislocations that produce unrelieved stress in individuals" (2006:6-7).

Could the same be said about the Jingle Dress and Dance? As the myth of its 
origin has been orally transmitted, we do not know the name, nor the tribe the man belonged to, nor where he lived, nor his sick daughter's name. We know nothing about his community and his status within it, or when he experienced the vision of the jingle dance dress. We can deduce therefore that he was one of those individuals who strongly believed in the power of the Great Spirit or Creator and sought his assistance in restoring his daughter's health. Was he a conjurer 'of his own making, of his own kind'? Knowingly or unknowingly, he too played his part in restoring and/or transforming elements of ancient aboriginal ceremonies, especially one attributed with the power of healing.

Overall, there appears to be a common belief that sickness is prevented or cured by the shaking of hands, the shaking of tents, ringing of bells, and the jingling of tinkles on a dress while dancing.

\section{Discussion and Conclusion}

All North American Indians have experienced millennia of traditions in which the healing of a sick body or mind was at the center of many of their vital ceremonies. Indians of the central- and eastern Woodland nations in particular can look back to numerous healing traditions as evidenced by archaeological discoveries, their religious beliefs, myths and legends passed on orally over the generations. Their way of life appeared not only to have reached the nadir, but the very end of their existence as a people. With US and Canadian government programs installed and repressive laws passed, as well as attempts at total integration into the dominant society, cultural genocide seemed inevitable. Native people all over North America had become sick in body, mind, and spirit, their identity severely shattered. 
Yet, numerous rituals and ceremonies, some of them traditional, others acculturated, were practiced secretly and thereby kept alive. Chiefs, elders, shamans, prophets remained determined to pass on those ceremonies, myths, and healing rituals to anyone who still believed that their people would survive and have a future in this land, 'their' land. Only when the Canadian Indian Act (passed in 1876 and amended several times over the next decades) had its first major reworking in 1951, was the ban on ceremonies dropped, although the government's objective of assimilation into Canadian society was retained. Nevertheless, this revision of the Indian Act now gave Aboriginals the freedom and opportunity to continue their struggle in reviving sacred as well as public ceremonies such as the Potlatch, the Sun Dance, and many others. Cultural gatherings like powwows would become especially popular with the general public of which the Jingle Dress Dance, together with other female dances, eventually became a regular fixture. The revival movements that were already in existence and practiced persistently underground, were now finally able to appear openly.

The questions then to be raised are, 'what do these cultural movements ultimately mean, and how significant did the Jingle Dress Dance become as a native tradition during that time?' Native culture, or rather selected aspects of it such as ceremonialism, was then being demonstrated consciously and in organized ways (i.e. shows and powwows) as living proof of native survival, against all former legislated government oppression. Wilson explains that all revival movements are pro-native, though not necessarily nativistic. They all have acquired goals, artefacts, techniques and styles from the dominant Euro-American culture, but preserved elements of their native culture. $\mathrm{He}$ argues (in my opinion correctly) about the designation "syncretic" movements, since they virtually all arose after cultural contact with Europeans, all incorporating mythological 
elements from both native and European sources (1973:486). For most tribes, the syncretism in native religious practices had its origin in approximately the first century after European contact. The legislative bans of ceremonies by Canadian and American governments only intensified during the decades of oppression when the regaining of power for native individuals, especially Chiefs, elders, shamans, and band and tribal communities became vital as a vehicle for survival. In Wilson's words, the power in those movements represent for the believers a "collective salvation". They had a future, since they are "dynamic responses to changing circumstances, and are a most distinct expression of aboriginals' independence and aspirations. As such "they may become a key to the prospects of new nations". In order to re-organize native communities and nations, the revival movements used religion as an agency in which to preserve distinctive aspects of a very distinctive culture. Yet, the author points out that, despite a quiet development of pan-Indianism as evidenced in the Peyote cult, the Shaker Church, and the Powwow, a coherent transformation of religious movements among Indian people has been minimal (1973:453-454). At this point, the question arises whether, at that time, the various movements have "directed revitalization into political channels"? A partial answer is that "a religious clientele is not ... converted into a political association even by the dramatic declaration of national independence (Beck Kehoe 1989:132; Wilson 1973:455). A series of nationwide politicization of revitalization movements, religious and secular, still had a long road ahead. For the time being, and for the next decades, those movements certainly presented native people with a new and newly-distinct identity as Indians.

Through the emergence of prophetic movements such as the Ghost Dance, "awareness of Indian identity, as tribes with very different cultural traditions, were drawn 
into a new pattern of ritual". A new set of beliefs, dance styles, and songs were transmitted from one tribe to another, despite language differences. Ceremonies were borrowed from each other like the Sun Dance (among Comanches and Utes), and a circulation of myths occurred. People realized that rituals and myths had not been "unique tribal possessions", but had been learned from other people as was the case with the stories of the Peyote and the Powwow or Dream Dance (Wilson 1973:459-460). It has to be deduced therefore that the Jingle Dress Dance, as a Dream Dance, then found its way into the circulation of myths, dispersing from the eastern- and central Woodland tribes to north- and southwestern (Prairie) tribes. A new type of dress and a new dance and songs were dreamed by one man for his sick daughter. His dreams and the child's ultimate healing may have become symbolic for his community's and tribe's healing as a people, the healing from several hundred years of the invaders' oppression. It needs to be stressed again that virtually all revitalization movements' most vital aspect is 'the power of healing' of which the jingle dress dance is performing its own unique role. Indian people across North America were in great need of healing body, mind and soul, and still continue the healing process well into the $21^{\text {st }}$ century. Most instrumental, the gift of healing had now been bestowed on all native women who earnestly wanted to become jingle dress dancers. Although women had often acted as shamans and medicinal healers in the past, they had now become part of the 'inner dancing circle' in tribal and intertribal ceremonies, a cultural, gender, and historic transformation. There can be no doubt that Indian women, due to the geographic distribution of the Jingle Dress Dance, inevitably played a major factor in the reshaping of their identity as women and as healers.

It is a matter of debate whether the Jingle Dress Dance had, from the mid-1800s to the mid-1900s, become a revived ceremony and thereby a part of the revitalization 
movements or even of millennialism. No (non-native) literature attests to those probabilities. However, a 'second revival' of the jingle dress dance by Maggie White in the 1960s and its subsequent full acceptance into the powwow circuit, points in that direction.

A revitalization of Indian culture necessitated the recovery of their past, but a great deal of the past had already been permanently lost. Other native 'pasts' had become acculturated after 300 years of European contact. Many beliefs, myths and legends had lost their meaning or were not remembered at all, perhaps more so and even earlier among Woodland Indians than among Prairie- and West Coast Indians, since European contact began earlier for them. There appeared primarily one certain and reliable way for Aboriginals to revitalize important elements of their culture, namely through the process of prophesies and dreams. The Jingle Dress Dance, despite its rather late origin, was no exception. Beginning with a father's dream in the mid- or late 1800s, the Jingle Dress Dance tradition experienced a second "dreaming" in the first part of the $20^{\text {th }}$ century with the vision of Maggie White's father.

Cary Miller raises the issue of 'tradition' eloquently by disagreeing with scholars who, in a strictly European context, regard the Jingle Dress Dance as non-traditional. Those scholars conceptualize tradition as "inherently associated with a linear perception of time". In Western culture, time is "abstract, separable from natural phenomena" in which a day has 24 hours, not a day followed by a night". For the Anishnaabeg (Ojibway), the indigenous perception of time is that of "recurring cycles, divided by the seasons, the seasons by the moons, and the moons by day and night". Their understanding of the past therefore is "that it will become realizable again in the future". Another understanding of time is the experience of the "senses of the soul" for which time is 
concurrent". Through the senses of the soul, the Anishnaabeg receive information from the spirits that exist across both space and time, including the age described in the oral tradition". It is vital to understand the meaning of tradition and its link to time from an aboriginal perspective. To 'regain their past' can only be achieved through communication with the spirits and, as Miller explains, the "primary source of information open to the senses of the soul is that of dreams and visions" (1995:2-5, 7-8). As pointed out in the previous chapter, the first (of two) modern Jingle Dress Dance traditions may be a new introduction or a 'dream invention' of an old, dormant tradition, just as the use of jingles and tinkles made from natural products (shells, bones) and copper predate European arrival. The second and better-known tradition, that of Maggie White, can be claimed as autobiographical. In at least one interview, Miller (1995:57) described the event that made her the 'first' jingle dress dancer after a dream, at the age of eight and after she had regained her health. The jingle dress was "her medicine". When Maggie White introduced it for the first time at a powwow, she insisted on the use of very simple and natural materials, and on very specific steps to be danced. She was most anxious to teach new dancers her specific style, thereby providing the dress and dance with the necessary dignity, elegance and respect to become accepted as a healing ceremony and to soon enter the powwow circuit throughout eastern- and northern America. There is no doubt that without Maggie White's authoritative teaching, the Jingle Dress Dance would not have become the traditional mainstay it now is.

It can be said that Maggie White, as an Ojibway woman of the eastern Woodlands, 'gave' aboriginal women the jingle dress and dance, together with its powers, responsibilities, and its history, however short. This fact ultimately leads me to the issue of gender. I shall not address here this matter as regards native female - male relationship 
in its long history, only as far as it is linked to the Jingle Dress Dance tradition.

The Hopi say that "A Nation is not conquered until the hearts of its women are on the ground". In the past, native women exerted great influence, particularly in matriarchal cultures such as the Iroquois (Mancini Billson 1995:17). European - Native contact caused unprecedented changes in native societies but, as Gunn Allen states, five centuries later, the recovery of their culture and traditions is proceeding at a rapid pace. Although Indians have based their diverse social systems "on ritual, spirit-centered, women-focused world-views", both women and men are "carriers of the dream" of new cultural movements (1992:IX, 2). Until about 20 years ago, the cultural revival took place mainly on reservations, for women more so than for men. An increasing number of men began migrating to the cities in search for work and, in the process, created new aboriginal communities. However, due to colonization, women's status in tribal communities, as Stan Steiner (in Gunn Allen) observed, had declined and weakened, they too began to migrate to cities in growing numbers. There, they are able to "regain the self-sufficiency and position of influence they had held in earlier centuries", and "In the cities the power of women has been recognized by the extra-tribal communities", and their election to tribal leadership positions in urban centres, since the 1960s, has been a new development in modern aboriginal life (Gunn Allen 1992:30-31).

Unfortunately, life in the cities affected many Indians negatively (i.e. unemployment), often resulting in alcohol- and drug-abuse. Since Maggie White lived on a large reservation, far away from any large city, it is speculative to which degree she was aware of those problems. She died in 1991. My personal interviews with aboriginal women, however, suggest a fairly strong connection between the Jingle Dress Dance and life in the city, again because of the healing powers attributed to it. Not all native men 
living in cities are familiar with the jingle dress tradition, but those who know Ojibway culture, respect the fact that it is a women's dance and a healing dance. One of my female informants had emphasized strongly the importance of 'their' dreams. It is more common for women than for men to receive dreams. Their dreams will tell them how the finished jingle dress must look, as well as the feasting of the dress after its completion, so it will be fully accepted and respected by the men and women within their families and communities. Behavioral and alcohol problems by two male members, as well as her own 'identity crisis' were gradually healed after she introduced the jingle dress and dance into the family. Her family and urban community soon realized 'the spirit of the healing power of the dress'. When healing occurs through the sound of the jingles, the sound of the drum, and the dancing of the appropriate steps, she feels empowered as a healer, as a woman, and as a First Nations Indian. Miller draws attention to the Anishnaabeg belief that jingle dress dancers do not need to fast in order to communicate with the spirits, as is the case with male dancers. This is because the Jingle Dress Dance is performed by women. "Women have a special tie to life-giving birth and energy embodied in mother earth through their womb ... Through the ability to give birth they also connect to the spirit world ..."(1995:14). Yet, other Ojibway communities strongly believe in the abstinence from certain types of food while women are producing the dress and apply the jingles, one each day. Obviously, there are variations in belief from tribe to tribe. My male informant, in his "Healing and Wellness Program", spoke of the "life cycle" which focuses on Aboriginals of all stages in their lives - as infants and as children, as teenagers and young adults, as grandparents and elders, encompassing families and communities. He stressed the importance of culture-based healing, primarily for native people whose knowledge of their own cultural practices, beliefs and languages 
are limited or entirely absent. This may include taking someone from an urban environment to a social or cultural gathering such as a powwow or a 'sweat' (sweat lodge) outside the city. Another aim is for young natives to learn about other Nations' customs and practices, and to understand and respect them. His program assists native people to acquire healthy life-styles by learning about their ancestors, by becoming aware of who their healers, the medicine people and herbalists are in order to conduct the necessary healing ceremonies for them. His aim is to provide the kind of support to those who request it, that will empower them to make healthy, positive decisions, to build selfesteem and self-love. I posed the questions 'whether he also proposes the Jingle Dress Dance as part of the healing process', whether it is included in his healing program and plays any role in it'. In his reply he admitted that he was only vaguely familiar with the jingle dress tradition. No Aboriginal had so far requested a specific ceremony, but he would not hesitate to propose the dance for healing purposes should a woman or man wish to have it performed.

The Jingle Dress Dance is native women's only healing ceremony. It has spread among eastern Woodland tribes and to other regions of North America. It increasingly gained acceptance, respect, and esteem over the past half century. Who can determine whether the healing- or medicine powers of a Sun Dance or a Sweat Lodge, or that of the Shakers are stronger, more forceful or prevailing than the Jingle Dress Dance? The many positive aspects this dance has realized over several decades need to be more strongly emphasized. Native women, since ancient times, are attributed with virtually equal influence with native men in their knowledge of healing and medicine. To credit the Jingle Dress Dance equally with male-ceremonies is in all Aboriginals' interest. Gunn Allen states that "among many if not most tribes, important ceremonies cannot be held 
without the presence of women" (1992:47). This follows that, with the jingle dress dance, Indian women possess their very own healing- and medicine ceremony, performed by those individuals who, as is believed, have a special gift bestowed on them by the Creator'. A great deal of the power and sacredness of the ceremony is attributed to Maggie White (who also 'owned' the origin story). It was due to her introduction of the jingle dress and dance at a native gathering (or exhibition) in Minnesota, that it crossed from the Canadian border into the US. This event spelled the beginning of the jingle dress dance as a category at powwows. At the same time this begs the following question: Would the jingle dress and dance have gained wide recognition had it remained outside the powwow circle? Did it necessitate such public exposure in order to become a cultural symbol and a medium for aboriginal women's identity?

Before I can attempt to answer these questions it is necessary to describe briefly what a powwow is, as well as why and how powwows became a popular form of cultural expression among North American tribes. The word 'powwow' is derived from the Ojibway "pauau" which, long before European contact, was "a curing ceremony where spiritual leaders came together for healings", involving singing and dancing (Roberts 1992:29). Until the advent of the inter-tribal competition powwow in the early 1900 s, as stated by J.C. White, "dances were performed only by elite societies for the benefit of tribal elders and tribal dignitaries". The powwows were social and political gatherings, feats of bravery and achievements were honoured, betrothals announced, weddings and births celebrated, deaths mourned. Elders would make decisions affecting the lives of tribe members for the coming year. Much feasting took place, but only the warriors danced $(1996: 25,20)$. This account lists more activities than Robert's. Yet, neither their writings nor that of any other non-native (or native) scholar have I found a detailed 
description of those types of powwows, of who precisely and how many people took part, how the ceremonies proceeded, whether they were tribal only, or how long they lasted. Also, no historical time-frame is given in their writings. The historic and pre-contact powwow is worthy of further research, especially when taking into account its present popularity throughout North America. Whatever part Indian women may have played, such information has been almost completely omitted.

To non-native people, powwows were regarded as threatening, war-like ceremonies and were legally banned in the US and Canada like the many other ceremonial gatherings described earlier. After the lifting of the ban, non-natives eventually discovered that a powwow is primarily a large social gathering were Indians celebrate their renewed and revived heritage, where they demonstrate their diverse culture, wearing their finest regalia, performing social and spiritual songs and dances. It was certainly not a threatening place. In Hills opinion, the powwow "serves as a vital catalyst for cultural renewal", having spread from coast to coast. What makes it so is the fact that Indians have been gathering to dance long before the first Europeans arrived on their shores. Their dancing tradition is "a powerful metaphor for expressing ancient beliefs that transcend modern realities". Each generation of Indians has to learn its own songs, dancing steps, drumming, produce its own regalia, then come together "as a people, united by tradition and connected in the certain belief that dance is essential to the expression of ourselves" (1996:7). This is a well-expressed sentiment. But again further research would perhaps also reveal in which ways Indian women expressed themselves during social and spiritual gatherings. Not only do ethnographic and anthropological accounts contain sparse references to women's dances, they contain no information (prior to the 1960s) as regards the Jingle Dress and Dance in particular. 
Occasionally there is mention of female initiation rituals among eastern and other regional tribes, and those of women shamanistic or healing rituals. However, these were apparently not performed during major gatherings. Kerisit, in citing several scholars (Hatto, Young), informs us in her thesis that among Northern Plains tribes, women often assisted men in singing, but never danced, though after the 1890 s they would participate in dances. Roberts, on the other hand, asserts that women used to join in the powwow dances when the men re-enacted their war deeds "by dancing around the edge of the dancing area". Prior to life on the reservations, women were also not allowed to take part in socialized dancing, but would only observe the men's dancing "from the sides". Walker omits to explain why such a gender division existed in ceremonialism and whether it affected Ojibway tribes only. Certain social dances such as "Round Dances" and "Forty-niners" were then added to men's Grass Dance and both women and men would dance together. During those early years of women's participation, exchanges of dancing paraphernalia and of songs took place, especially during "shows" organized by white settlers (Kerisit 1989:18-19; Roberts 1998:106-108; Walker 2001:68).

As regards the jingle dress, none of the women in the archival photographs I found, from the earliest of 1905 to the later ones of the 1920s and 1930s, indicated in any way that these girls and young women had danced in their jingle dresses, but simply dressed up for a festive occasion. Walker (2001:10) points out (in a footnote) that the jingle dresses worn by Ojibway women prior to the 1960 s were not called jingle dresses. Yet, she does not mention what those dresses were called which her extensive interviews with Maggie White's descendants might have revealed. It is possible that a dance existed, perhaps even a medicine or healing dance, which the women performed in secret locations only, away from the eyes of missionaries and government officials. Obviously, 
the dress, in its rather simple form with metal cones as jingles, had been known among Woodland tribes, yet I would theorize that old or even ancient songs and dance-steps had once existed, but were lost or became dormant during the century after European contact. Then, during the Pan-Indian movement of the 1960s and 1970s, Ojibway women danced the Jingle Dress Dance at powwows together with Traditional and Fancy Shawl dancers.

From interviews with some of Maggie White's female descendants, Walker learned that after Maggie's introduction of the jingle dress dance to the powwow circuit, the jingle dancers were usually requested "to go to the end of the ladies Traditional Dance category". This did not change until the early 1980 s when the jingle dress dance became recognized as a dance category. As the dance flourished, dance troupes were (and still are) often divided into two dance categories - traditional and contemporary (2001:11). The traditional jingle dance exists in four individual styles - Southern and Northern, Buckskin and Cloth (Powers 1990:58-60). Due to the changing roles of women in general and Maggie White's presentation of the dance to the powwow, native women have been full participants in the dance circle.

At this point I want to return to my personal interviews with two jingle dress dancers. They stressed again and again the medicine and healing power of the dress, regardless of the type of powwow they appeared in. Dancers must be aware at all times of 'the spirit of the dress'. One dancer had attended a traditional powwow in her community in which the giving and receiving of tobacco was a vital ceremonial component. In return, community members received jingle songs, dances and prayers for sick persons. After the dance, the tobacco is offered to the fire. One informant "felt bad" about dancing jingle dress in competition powwows. Being very conscious of the healing power and spirit of the dress, she decided to switch to Fancy Shawl dancing. The Jingle Dress Dance, in her 
opinion, should never be part of competitive powwows and not be performed for price money. She only dances jingle when a sick person requests it from her.

It appears that many of the jingle dancers who are most familiar with the tradition, prefer traditional powwows. Hill, a powwow dancer, almost resented the powwow as "the ultimate insult" to Indian dancing cultures because of the fierce competition for price money. Still, he continues dancing, with the statement "The powwow has become our light in a very dark world" (1996:7).

When I posed the question whether the Jingle Dress Dance tradition has a future in the $21^{\text {st }}$ century, my informants agreed that the tradition is still growing; it is a dance more young girls want to perform because they are drawn to the sounds of the jingles. One dancer however expressed her concern as to the teachings of the tradition. Will young future dancers learn enough about the responsibilities for the regalia, about its meaning for their families and communities? It is vital that they follow the teachings that go with the dress. Nevertheless, she is convinced of the Jingle Dress Dance's future for many generations to come. Maggie White's traditional style has gained great popularity, although the steps are more difficult and more demanding on the body. In her opinion, a return to the Jingle Dress Dance's traditional teachings will be followed by a general return to a more traditional native way of life! The elders and grandmothers will have to play a more prominent role since not all parents remember or even know about the Jingle Dress Dance's past. It deserves respect at all times.

As a general end-note about powwows I will cite Christ Roberts: "Nowhere is this growing pride and concern for traditional ways more evident than at powwows - the heartbeat of Indian County" (1992:8). In the words of Maggie White's granddaughter, "the Jingle Dress Dance will continue with the future generations. This is our story, my 
grandmother's story" (Walker 2001:9).

\section{Concluding Remarks}

Although I was aware from the outset of my research into the Jingle Dress Dance that it was likely not simply an ancient ceremony, but possibly combining ancient traditions, I thought it essential to present an overview of eastern Woodland Indians' beliefs and religious practices as evidenced from archaeological finds, beginning in prehistoric times. Humans everywhere use myths to interpret the past and create new myths to deal with current problems, as well as new prophesies to help them overcome and heal past traumas and to help them in creating a new and better future. This way, their cycle of life can proceed in accordance with their new 'cosmic belief' which is acted out in songs and dances that are giving fresh meanings to their identity. All contemporary ceremonies play an active role in promoting this new sense of Indian identity. The Jingle Dress and Dance functions as a vital part towards achieving a better future. As a women's healing dance it has already found its place among North American ceremonies, from the Woodlands to the Prairie regions. I reached the conclusion that, ultimately, it is not of great importance whether the Jingle Dress Dance tradition has an ancient or more recent history. Native people themselves, such as the Ojibway, attach little significance to this aspect of the jingle dress. Miller makes western scholars aware of the Ojibway's (Anishnaabeg's) different conception of tradition and of history. "It is rooted in a different perception of time" which produces an alternative understanding of the world. Thus, in their viewpoint, "the very existence of the jingle dress dance demonstrates the continued vitality of their tradition because it continues those links to the spirits" $(1995: 81-82)$. 
And what shall we make of the jingles and tinkles? Their use is definitely entrenched in ancient customs, ceremonial as well as ornamental. Their links to healing practices among many North American tribes, east and west, to ward off sickness, seems undisputed. Nevertheless, this type of ornamentation, dating back millennia, is worthy of further research. On the jingle dress, the cones 'make' the dress, it has no purpose and meaning without them. They, it is believed, ward off the sickness brought on by bad spirits; their tinkling sounds during the dance will heal the afflicted person. The similarities in belief and practice between shamans in the past, who used tinkle- and bell paraphernalia, and jingle dress dancers in the present are certainly apparent.

To draw the various aspects of my thesis topic to a definite conclusion is not easy. My hypothesis is that the Jingle Dress Dance evolved out of the needs and will by Indian women over the past 100 to 150 years (or even earlier) for a strong identity of their own. Like aboriginal men, they were confronted with a myriad of stereotypes, resulting in prejudices of many kinds, generated by the European invaders and settlers. The originally purely decorative jingles (whether produced of natural materials or metal such as copper and tin) on women's festive dresses evolved into a regalia which transmits their newfound spirituality. Through women of the Woodland regions, prominently Maggie White and Maggy Wilson, as well as some tribal chiefs who all experienced 'the dreams', a medicine and healing tradition was conceived and/or transformed. It would help to bring medicine and healing to those women and men in need.

Nevertheless, I deduce that the transformation of the jingle dress and dance, generally, took place 'more' in its outward appearance (i.e. regalia, songs, steps) than in its symbolic expression. We simply do not know what the jingle dress meant to Indian women a century ago. 
The main or possibly only conclusion I can sincerely derive at is that, for over half a century, healing and medicine have been the essence of Indian ceremonialism in order to gain some equilibrium in their post-colonial lives. To bring emotional, spiritual, psychological and physical healing to the people within their families, communities, and Nations has become the main focus of the Jingle Dress and Dance. However, not every young or new dancer (as one of my informant pointed out) is knowledgeable about this factor.

Throughout my research for this thesis it became increasingly clear and needs to be stressed that healing and medicine in various forms are at the center of many contemporary Indian ceremonies and festive gatherings. Unlike in pre-European times, the collective' dis-ease' that has afflicted aboriginal peoples in North America for many generations was introduced by foreign invaders. At this point, let's further look at the healing process in native terms, that is 'symbolic healing'. Waldram asserts that “"healing' and 'illness', as opposed to 'curing' and 'disease' are cultural constructs". While bio-medicine concentrates on the "body and mind as separate biological entities", the indigenous medical system focuses more on the body and mind as a whole, "and how illness is symptomatic of an imbalance between the individual, the society, and the spiritual realm". This type of healing depends greatly on the use, interpretation, and manipulation of cultural symbols. It is central to the healing process. He emphasized the use of symbols, the interchange of language and other forms of communication between healer and patient, and the importance of helping the patient to understand the problem. Such understanding assumes "that the language and symbols used are meaningful for both the healer and the patient". Citing James Dow, symbolic healing "involves the generalizing of social and cultural experiences through the use of symbols specific to the 
culture". Such symbols are embedded in cultural myths, containing "the 'truths' of the culture as the people understand them". Symbolic healing therefore is concerned with the social side of the illness such as trauma and dysfunction, rather than curing bio-medically (1997:71-73). Waldram then asks the vital question, 'does it work?'. His answer, in the affirmative, stresses the point "that the healer's role in symbolic healing is more proactive and interactive, using Claude Lévi-Strauss' argument "that the healer is, in effect, also a symbol onto whom the patient transfers his or her emotions in a process known as 'transference"'. The healer is the individual and living proof that transformation and healing can be successful (1997:205).

My informant, an expert on healing and wellness, explained it this way: In the case of a male who asks him for help and guidance, his first act must be the presentation of tobacco. This is the very beginning of the healing process if the person is sincere about his intent. The individual thereby demonstrates his determination, effort, and commitment to learn which traditional lifestyles he wishes to follow. After a pre-assessment (and receiving information on his tribal background or nationhood) he may be referred to the appropriate person or elder. A trusting relationship needs to be established for all people concerned and the new lifestyle must be in accordance with the individual's tribal customs, beliefs and practices. He will then be able to decide whether a healing ceremony such as a 'sweat' is appropriate. He wants natives to become aware of "how important spiritual value really is".

This is a synopsis only of the rather in-depth healing process described to me. In the words of my informant, "It takes forever, getting to know its in-depth sacredness, it is an ongoing life-journey and not everyone will follow this way; it is not easy, actually it is hard". Similarly, an individual or community who requests a Jingle Dress Dance to be 
performed, this healing process also begins with the presentation of tobacco. The dancers are honoured through the gift of tobacco from the requester. They in turn honour the singers and drummers when raising their fan (usually a feather) during the dance, and the jingles' sounds 'warding off or dispelling' sickness. Like other healing and medicine ceremonies, the Jingle Dress Dance too needs to be repeated over a certain period of time (see Fig. 23).

A Salish (Northwest Coast) Indian doctor once referred to the distance past when "the gift of obtaining power, and of healing through power was universal to all Indians"; it was part of their Indian ways. This power has been lost now by most of those doctors because they tried to emulate the white man who lacks this 'Indian power". In the old days, Indians were strong; every old man and old woman was a doctor then. In the present day, a contemporary Salish ritualist still initiates the sick person into sye 'wan to cure him or her. The ritual buries the afflicted person's ailments together with their old personality. At the same time, the person is given rebirth, a new life. This ritual is performed when western doctors and hospitals have given up (Jilek 1974:64-65). Jilek presents here an example of a "death- and rebirth myth", a therapeutic myth, the central theme of the spirit dance initiation. Contemporary ceremonies and rituals of this kind, and others like the Ghost Dance, the Shakers, Potlatch, Sweatlodge and, lastly, the Jingle Dress Dance, are all part of the revival of the ceremonial, following decades of suppression and domination. The author, a physician and psychiatrist, witnessed such revivals among Northwest Coast cultures over many years. In his assessment, such traditional functions provide the local aboriginal population with a "treatment program in which several types of well-defined therapeutic procedures are integrated" (1974:iii). 
Figure 23

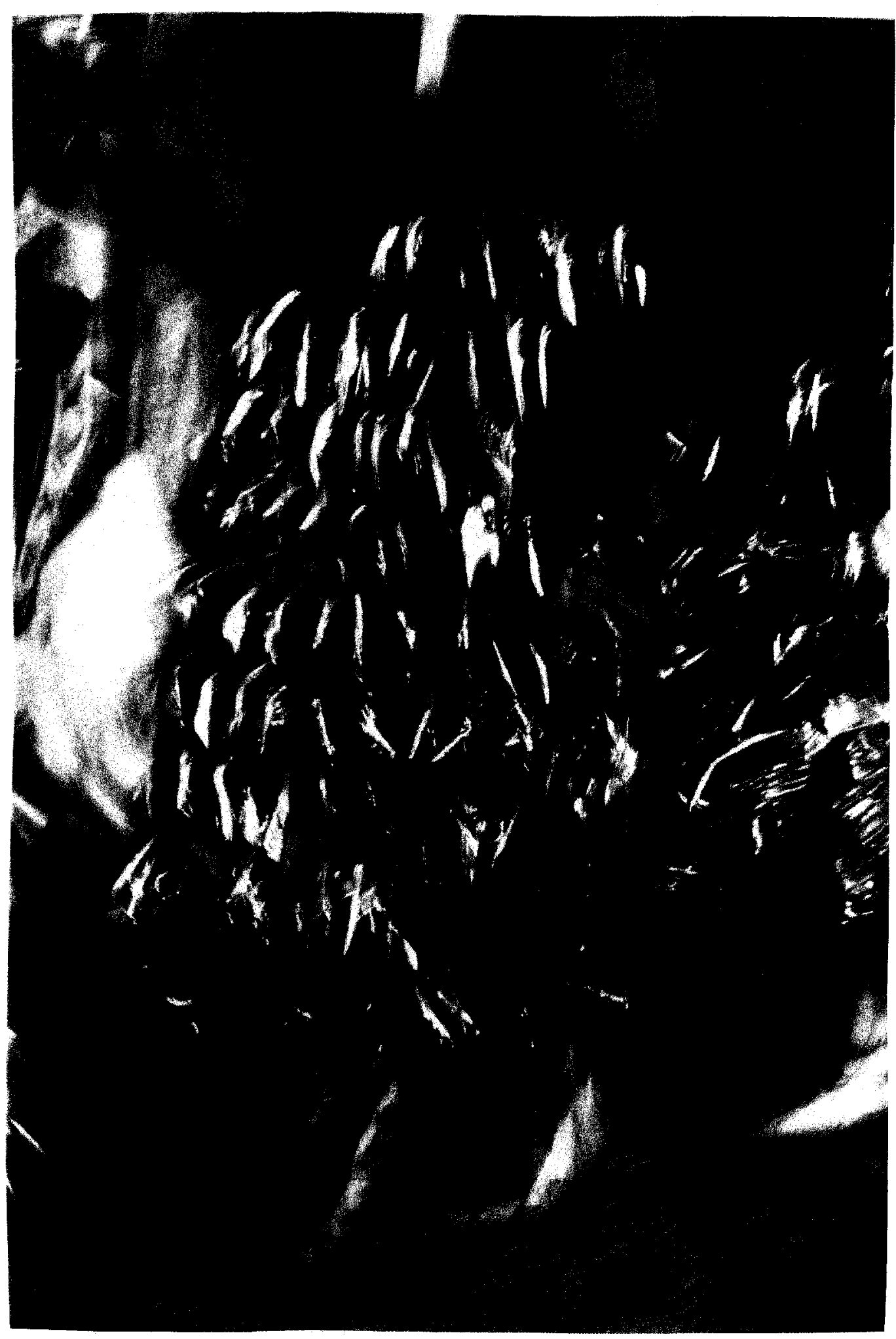

Iingle Dress Dancer

Marra,B. "Powwow - Images Along the Red Road" (1996) 
Jilek further asserts that revived traditional customs are decisively important for aboriginal people's self-esteem, their enjoyment of living, even for their will to live. They function "in the service of the Indian people's mental health and survival, today more than ever before" (1992:6). This evaluation contrasts somewhat with an earlier one by Lévi-Strauss who believed "that all therapies are similar" and, from a functional viewpoint, it makes no difference whether a patient's curing procedure is called "psychoanalysis or ritual curing" since, in the long term, it depends on the "sense of security that the group receives from the myth underlying the cure and from the popular system upon which the group's universe is reconstructed" (Powers 1987:144). It could be alleged that both Jilek and Lévi-Strauss are correct in their assessments; yet I want to give Powers the last word on the matter: The white man's work is destroyed through a constant stream of constructions and deconstructions, thereby "fulfilling the collective longing for a better world". It is "through the superiority of the Indian over the white man ... that the Indian universe survives" (1987:146).

It is difficult to conjecture to what degree the Jingle Dress Dance tradition will be helpful in the more distant future as a 'therapeutic myth' to Indian communities, to those living on reservations and those in urban environments. Yet, its present popularity provides great opportunities for future growth and success. Urban communities especially (as some personal interviews revealed) are in need of cultural awareness, an awareness to be passed on from the women to their children. Joe and Lonewolf Miller raise the point that, in most tribes, it has been the role of women to preserve the "cultural strength" that keeps tribal identity and families together, but when Indian women move to urban centres, the continuity of their culture is threatened. It is mothers who teach about Indianness (in Baca Zinn and Thorton Dill, eds. 1994:187).

The very existence of the Jingle Dress Dance and the way it evolved over a 
century at least, its present strength and vitality, its links to the spirit world and powers of healing would assure the tradition's continuity in the $21^{\text {st }}$ century. It could also be of benefit to non-aboriginal people.

\section{Assessment of Thesis}

The purpose of my thesis was to increase awareness and knowledge, in whatever small way, of the Jingle Dress and Dance, a tradition that originated among the eastern Woodland Indians, and to present as comprehensive a picture as possible. I attended three outdoor and two indoor powwows in the Ottawa region. One of the ceremonies included a Jingle Dress Dance for the specific purpose of assisting in the healing of an Indian boy. I also had opportunities of interviewing three aboriginal people, two of them jingle dress dancers.

Apart from extensive literature research, I searched the Library and Archives Canada, the Canadian Museum of Civilization (CMC), as well as the museum's extensive archives and library. Early in 2008, I had the opportunities to visit the Royal Ontario Museum (ROM, Toronto), and the Museum of Anthropology (Vancouver). While in the ROM, I was able to speak to two curators about my thesis project and enquire about a possible viewing of certain types of artifacts. Unfortunately, the process to be granted permission would have taken a considerable amount of time and I had only two days left in Toronto. The situation turned out very similar during my stay in Vancouver. Also, my various attempts to contact the Wabano Center for Aboriginal Health (since 1998 in Ottawa), were without success.

During my fourteen-months research into the Jingle Dress Dance I was at times surprised, even perplexed about the scant knowledge of this Indian regalia, even by professional staff in museums and archives. It became obvious that the Jingle Dress 
Dance has so far aroused little interest and, therefore, the written records, documents and photographs are extremely limited, especially when compared to aboriginal men's regalia. Yet, a fair amount of information is available on the world-wide-web, though most of it is general and in reference to powwows only. A few informative videos, however, are available for purchase. During the powwows I attended, most native women showed surprise when I mentioned my thesis topic to them.

Under somewhat different circumstances and with unlimited resources, I am certain that an even more comprehensive knowledge would have been the outcome. More exhaustive research on the topic would definitely be appropriate. Here I want to list what further investigation could be undertaken:

1. extensive travel to various eastern and central Woodland tribes to conduct interviews with jingle dress dancers (and female dancers in other dance categories), and other people in their communities, including Chiefs and Elders;

2. travel to tribes such as the Hopi who also claim to be the originators of the jingle dress;

3. to witness or participate in the production of the dress and regalia, and to learn more about its symbolic value;

4. to view the numerous pre-historic and post-contact archaeological artifacts, especially as they refer to jingles and tinkles;

5. to view and study any available objects or artifacts of Indian female dresses and/or regalia as far back in history as possible, to gain greater knowledge about the role they played in every-day use and on ceremonial occasions, as well as their production and transformation over time;

6. to gain an overall picture as to what the Jingle Dress Dance tradition means to the many different tribes and Nations, as a spiritual and social experience. 
At the end of this project I want to reflect on what has been accomplished: I presented an overview of the geography, ancient history, mainly based on certain types of archaeological finds, and some post-contact history of the Eastern Woodland Indians. However, for the sake of my thesis topic, I always had to keep in mind its links to their religious beliefs, their spirituality as expressed in certain ceremonies and rituals. And the main focus here is a specific area of Indians' material culture with its symbolic meanings. It could be established with certainty, based again on archaeological finds in numerous burial mounds and grave sites, that a variety of medicine-, conjuring- and healing paraphernalia were produced and used in prehistoric times. As well, jingles, tinkles, and bells already had their specific purpose among those objects.

A close examination of the Jingle Dress and Dance revealed a strong belief in the medicine- and healing powers according to myths, dreams or visions that 'gave birth and meaning' to this ceremony. How and why it became an entirely separate ceremony is a unique occurrence among Woodland Indians. A great deal of native women's pride and a strengthened sense of identity is closely linked to the Jingle Dress Dance and cannot, in the foreseeable future, be separated from it. It also became clear that aboriginal men became to recognize, acknowledge and greatly respect this fairly recent healing ceremony. Lastly, after examining several other healing ceremonies which had undergone transformations during the $19^{\text {th }}$ and $20^{\text {th }}$ centuries (i.e. Ghost Dance, Sun Dance, and syncretic religions such as the Shakers), it is evident that the Jingle Dress Dance too is part of Aboriginals' cultural and religious revitalization movements.

By the end of writing this project I had gained a better understanding of the vital, purposeful role one type of regalia and one type of ceremony can play, not only to the individuals who use and practice it, but also to their families, communities, and their whole Nations. My wish is for a wider audience to discover the uniqueness of this facet of 
native Indians' lives.

I want to let Chief Dan George have the last word: "Unless there is integration of hearts and minds you have only a physical presence and the walls are as high as the mountain ranges." (Page and Da Rosa 1982:160). 


\section{References}

Adams, Nicholas R.

1995 "Ontario Prehistory - An Introduction". http://www.adamsheritage.com/pre/preont1.htm (Dec. 11, 2005)

Adelson, Naomi

1997

"Gathering Knowledge: Reflections on the Anthropology of Identity, Aboriginality, and the Annual Gatherings in Whapmagoostui, Quebec", in AGREE Discussion Paper No. 1. Montreal: McGill University, pp. 289303

Alfred, Agnes

1980 "Enter the Collection ..." http://schoolnet.ca/aboriginal/umista2/potlatche.html; (May 20, 2007)

Ames, Michael

1992 "The Emerging Native View of History and Culture" in Cannibal Tours and Glass Boxes. Vancouver: University of British Columbia Press

Amoss, Pamela

1978

"Symbolic Substitution in the Indian Shaker Church" in Ethnohistory, Vol. 25, No. 3 (Summer 1978), pp. 225-249

Anonymous [a]

n.d.

"Crucibles for Casting found at Cahokia: Neiburger's Evidence: Native Americans Melted, Cast Copper at 1000 BC Site";

http://www.jwaynet.net/-wdc/copper.htm (Nov. 7, 2007)

Anonymous [b]

n.d. "Hopewell Culture - Mound Builders"; http://www.britannica.com/eb/topic-271480/Hopewell-culture (Nov. 7, 2007)

Anonymous [c]

n.d.

"Copper in Ancient and Modern Myths and Legends" in Healing properties of Copper, Mental, Physical and Spiritual from the New Age and Medical Centre; http://www.jewelreysupplier.com/2copper/ copper mythology.htm (Nov. 7, 2007)

Anonymous [d]

2008 March "Indian Shaker Church". http://www.en.wikipedia.org/wiki/Indian_Shakers (May 14, 2008) 
Anonymous [e]

1978

"Indian Shaker Church of Washington Records".

http://www.washingtonhistory.org (May 14, 2008)

Axtell, James (ed.)

1981 The Indian Peoples of Eastern America - A Documentary History of the Sexes. New York: Oxford University Press

Baca Zinn, Maxine and Thornton Dill, Bonnie

1994 Women of Color in U.S. Society. Philadelphia: Temple University Press

Baldueck, Sarah (contributor)

n.d. Oconto County WIGen Web Project, "Copper Culture Burial Site"

http://www.rootsweb.can/-wisconsin/copper culture cemetery.htm; (Dec. $\underline{3,2007)}$

Barnett, H.G.

1957 Indian Shakers - A Messianic Cult of the Pacific Northwest.

Binghampton, N.Y.: Vail Ballou Press

Bataille, Gretchen M. (ed.)

2001 Native American Representations - First Encounters, Distorted Images, and Literary Appropriations. Lincoln and London: University of Nebraska Press

Bates, Craig D.

1982 "Dressing the Part: A Brief Look at the Development of Stereotypical Indian Clothing among Native Peoples in the Far West" in Journal of California and Great Basin Anthropology, Vol. 4, No. 2, pp. 55-66

Battiste, Marie (ed.)

2000

Reclaiming Indigenous Voice-Vision. Vancouver: University of British Columbia - UBC-Press

Beck Kehoe, Alice

1989

Case Studies in Cultural Anthropology - The Ghost Dance: Ethnohistory and Revitalization. New York: Holt, Rinehart and Winston

Behiels, Michael

1999

"Being Aborigine: The Cultural Politics of Identity, Membership and Belonging Among First Nations in Canada" in "Futures and Identities. Montreal: Association for Canadian Studies 
Berbaum, Sylvie

2000 Ojibway Powwow World. Thunder Bay: Centre for Northern Studies, Lakehead University (Ph.D. Dissertation)

Berman, Karen

1997 North American Indian Traditions and Ceremonies. Greenwich:

Brompton

Books Corporation

Bird, S. Elizabeth (ed.)

1996 Dressing in Feathers. The Construction of the Indian in American Popular

Culture. Boulder: Westview Press

Blundell, Valda

1993 "Echoes of a Proud Nation: Reading Kahnawake's Powwow as a Post-Oka

Text" in Canadian Journal of Communication, Vol. 18, pp. 333-350

Bolz, Peter; Sanner Hans-Ulrich

1999 Native American Art - The Collection of the Ethnological Museum Berlin.

Berlin: Staatliche Museen zu Berlin - Preussischer Kulturbesitz und G+H

Verlag

Brose, David S.; Cowan, C. Wesley; Mainfort, Robert C. Jr. (eds.)

2001 Societies in Eclipse - Archaeology of the Eastern Woodlands Indians, A.D. 1400 - 1700. Washington and London: Smithsonian Institution Press

Brown, Jennifer S.H.; Brightman, Robert

1988 The Order of the Dreamed: George Nelson on Cree and Northern Ojibwa

Religion and Myth, 1823. Winnipeg: The University of Manitoba Press

Browner, Tara

2002

Heartbeat of the People - Music and Dance of the Northern Pow-wow.

Urbana and Chicago: University of Illinois Press

Burke Leacock, Eleanor \& Oestreich Lurie, Nancy

1971 North American Indians in Historical Perspective. New York: Random House

Bursag, Jeff; Daechsel, Hugh; Hinshelwood, A.; Murphy, Carl

n.d. "The Archaeology of Ontario - Late Woodland Period". Ontario Archaeological Society. http://www.ontarioarchaeology.on.ca (Dec. 11, 2005) 
Canadian Museum of Civilization

n.d. "Arrival of Strangers - The Last 500 Years - Social Gatherings - The Midewiwin Society"; http://www.civilization.ca/oborig (Dec. 7, 2006)

Canadian Museum of Civilization

$1916,1949,1968,1970$

Audio Archives - Area III - Ethnology: Ojibway and Iroquois Medicine Songs

Carter, Sarah

1997

Capturing Women - The Manipulation of Cultural Imagery in Canada's

Prairie West. Montreal and Kingston: McGill-Queen's University Press

Cavanagh, Beverley D.

1989 "Music and Gender in the Sub-Arctic Algonkian Area" in Keeling, R., ed., Women in North-American Indian Music: Six Essays, pp. 55-66.

Bloomington:

The Society for Musicology, Inc.

Cave, Alfred A.

2006 Prophets of the Great Spirit - Native American Revitalization Movements in Eastern North-America. Lincoln and London: University of Nebraska Press

Ceram, C.W.

1978 Der Erste Amerikaner - Das Rätsel des vor-kolumbischen Indianers.

Reinbek/ Hamburg: Rowohlt Verlag GmbH

Codere, Helen

1950

Fighting with Property - A Study of Kwakiutl Potlatching and Warfare 1792-1930. New York: J. J. Augustin

Cole, Douglas \& Chaickin, Ira

1990 An Iron Hand Upon the People. The Law Against the Potlatch on the North West Coast. Vancouver: Douglas \& McIntyre

Densmore, Frances

1970 Chippewa Customs. New York: Johnson Reprint Company Ltd.

Densmore, Frances

1973 Chippewa Music. Minneapolis: Ross \& Haines, Inc.

Diamond, Beverley; Cronk, M. Sam; von Rosen, Franziska

1994 Visions of Sound - Musical Instruments of First Nations Communities in 
Northeastern America. Waterloo: Wilfrid Laurier University Press

Doxtator, Deborah

1992 Fluffs and Feathers. An Exhibit on the Symbols of Indianness. Brantfort: Woodland Cultural Centre

Dubin, Sherr Lois

1999 North American Indian Jewelry and Adornment - From Prehistory to the Present. New York: Harry N. Abrams, Inc.

Ewing, Douglas C.

1982 Pleasing the Spirit - A Catalogue of a Collection of American Indian Art. New York: Ghylen Press

Francis, Daniel

1992 The Imaginary Indian - The Image of the Indian in Canadian Culture.

Vancouver: Arsenal Pulp Press

Garcia, Louis

1971

"Dakota Jingle Dress" in American Indian Crafts and Culture, Vol. 5, Aug. 2006, pp. 16-17

Genheimer, Robert A. (ed.)

2000 Cultures before Contact - The Late Prehistory of Ohio and Surrounding

Regions. Columbus: The Ohio Archaeological Council

George, Leonard

1991 Native Spirituality, Past, Present and Future, in Jensen, Doreen and Brooks, Cheryl, "In Celebration of Our Survival - The First Nations of British Columbia. Vancouver: UBC Press

Gunn Allen, Paula

1992

The Sacred Hoop - Recovering the Feminine in American Indian

Traditions. Boston: Beacon Press

Hensel, Peter 1993

The Algonkin Nation. The Algonkins of the Ottawa Valley: An Historical Outline. Arnprior: Kichesippi Books

Herle, Anita

1994

"Dancing Community: Powwow and Pan-Indianism in North America" in Cambridge Anthropology, Vol. 17, No. 2, pp. 57-81 
Hill, Richard W.

1996 Powwow - Images Along the Red Road. New York: Harry N. Abrams, Inc. Publishers

Holm, Tom

2005

The Great Confusion in Indian Affairs. Austin: University of Texas Press

Hyde, George E.

1962 Indians of the Woodlands - From Prehistoric Times to 1725. Norman: University of Oklahoma Press

Jasper, Cynthia

1988 "Change in Ojibway (Chippewa) Dress - 1820-1980" in American Indian

Culture and Research Journal, Vol. 12, No. 4, pp. 17-37

Jensen, Doreen; Brooks, Cheryl

1991 Celebration of Our Survival - The First Nations of British Columbia.

Vancouver: UBC Press

Jilek, Wolfgang G.

1974 Salish Indian Mental Health and Culture Change: Psychohygienic and Therapeutic Aspects of the Guardian Spirit Ceremonial. Toronto: Holt, Rinehart and Winston of Canada, Ltd.

Jilek, Wolfgang G.

1992 Indian Healing - Shamanic Ceremonialism in the Pacific Northwest Today.

Surrey: Hancock House Publishers Ltd.

Johnston, Basil

1976 Ojibway Heritage. Toronto: McClelland and Stewart

Johnston, Basil

1982 Ojibway Ceremonies. Toronto: McClelland and Stewart

Johnston, Jim \& Maureen

1991 “Jingle Dresses" in Whispering Wind, Vol. 24, No. 2, Summer 1991, pp. 413

Johnston, Kay \& Nahanee, Gloria

2003 Spirit of Powwow. Canada-USA: Hancock House Publishing Ltd.

Kearney, Kathleen; Miller, Janet

1994/Spring "Defining a Nez Perce Feminine Dress Style" in Northwest

Anthropological Research Notes, Vol. 28, No. 1 
Kerisit, Michell

1989 Feathers, Furs and Fringes. A Semiological Analysis of Powwow Regalia. MA-Thesis. Ottawa: Carleton University

Koch, Ronald P.

1977 Dress Clothing of the Plains Indians. Norman: University of Oklahoma Press

Kohn, Rita and Lynwood Mantell W. (eds.)

1997 Oral Histories of Contemporary Woodland Indians. Bloomington and Indianapolis: Indiana University Press

Krech III, Shepard

1999 The Ecological Indian - Myth and History. New York: W.W. Norton \& Company

Landes, Ruth

1968 Religion and the Madden. Madison: The University of Wisconsin Press

Laubin, Reginald and Gladys

1979 Indian Dances of North America - Their Importance to Indian Life.

Norman: University of Oklahoma Press

Leitich Smith, Cynthia

2000 Jingle Dancer. New York: Morrow Junior Books (a division of William Morrow and Company, Inc.)

Mancini Billson, Janet

1995

Keepers of the Culture - The Power of Tradition in Women's Lives. New York: Lexington Books

Martin, Lee-Ann and Boyer, Bob

2000 The Powwow - An Art History. Regina: MacKenzie Art Gallery

Meeches Video Production

n.d. The Jingle Dress; The Sharing Circle, Season 17

Miller, Cary

1995 Rethinking Tradition: The Anishnabe Perception of Time and the Jingle Dress Dance as a Traditional Practice. M.A. Thesis; Chapel Hill:

University of North Carolina at Chapel Hill, USA 
Morris Bernstein, Diane

1996 We Dance because We Can. Marietta: Longstreet Press, Inc.

Page, Daniel H. and Da Rosa, Victor M.P.

$1982 \quad$ Heritage of the North American Indian People - Some Suggestions

Emphasizing the Eastern Woodlands. Ottawa: Borealis Press

Parfit, Micheal

1994 "Powwow - A Gathering of the Tribes" in National Geographic, Vol. 185, no. 6, June 1994, pp. 88-113

Pettipas, Katherine

1994 Severing the Ties that Bind: Government Repression of Indigenous

Religious Ceremonies on the Prairies. Winnipeg: University of Manitoba Press

Powers, William K.

1987 Beyond the Vision - Essays on American Indian Culture. Norman:

University of Oklahoma Press

Powers, William K.

1990 War Dance: Plains Indian Musical Performance. Tucson: University of Arizona Press

Prattis, Ian J.

1997 Anthropology at the Edge - Essays on Culture, Symbol, and

Consciousness. Lanham: University Press of America, Inc.

Prokosch Kurath, Gertrude

1986 Half a Century of Dance Research. Ann Arbor: Cushing Malloy, Inc.

Quimby, George Irvin

1966 Indian Culture and European Trade Goods. Madison: The University of Wisconsin Press

Ritzentaler, E. Robert, and Ritzentaler, Pat

1970 The Woodland Indians of the Western Great Lakes. Garden City: The Natural History Press

Roberts, Chris

1998 Powwow Country: People of the Circle. Missoula: Meadowlark Publishing Company 
Roberts, Chris

1992 Powwow Country. Helena: American \& World Geographic Publishing

Rossina, Kim Lindsay

2000 History of the Jingle Dress. M.A.-Thesis; University of Minnesota, USA

Schaeffer, Claude E.

1969 Blackfoot Shaking Tent. Calgary: Glenbow-Alberta Institute

Sexsmith, Pamela

2001 "Portrait of a Jingle Dress Dancer" in Wind Speaker, June 2001, p. 11 (http://find.galegroup.com/itx/retrieve.do; Aug. 25, 2006)

Sexsmith, Pamela

2003

"The healing gift of the jingle dance (buffalo spirit)" in Wind Speaker (http://find.galegroup.com; Aug. 25, 2006)

Sexsmith, Pamela

2001

"Next generation takes on dancing tradition" in Saskatchewan Sage, Vol.

10, No. 5, July 2001

Smoak, Gregory E.

2006 Ghost Dances and Identity - Prophetic Religion and American Indian Ethnogenesis in the Nineteenth Century. Berkeley: University of California Press

Snow, Dean R.

1994 The Iroquois. Cambridge: Blackwell Publishers

Stecklay, John L. And Cummins, Bryan D.

2001

Full Circle - Canada's First Nations. Toronto: Pearson Education Canada Inc.

Storck, Peter L.

1981 Ontario Prehistory. Toronto: Royal Ontario Museum

Stothers, David M.

2000 "The Protohistoric Time Period in the Southwestern Lake Erie Region: European Derived Trade Material, Population Movement and Cultural Realignment" in Genheimer, Robert A., ed., Cultures Before Contact - The Late Prehistory of Ohio and Surrounding Regions; pp. 52-79 
Thompson, Judy

1994 From the Land - Two Hundred Years of Dene Clothing. Hull: Canadian Museum of Civilization

Tinker, George E. "Tink"

2005 Spirit and Resistance - Political Theology and American Indian Liberation. Minneapolis: Fortress Press

Tooker, Elisabeth (ed.)

1979 Native North American Spirituality of the Eastern Woodlands - Sacred Myths, Dreams, Visions, Speeches, Healing Formulas, Rituals and Ceremonies. New York: The Missionary Society of St. Paul the Apostle

Trigger, Bruce G.

1986 Natives and Newcomers. Canada's "Heroic Age" Reconsidered.

Manchester: Manchester University Press

Trigger, Bruce G.

1978 "Northeast" in Handbook of North-American Indians, Vol. 15.

Washington, D.C.: Smithsonian Institution

Tuck, James A.

1978 "Northern Iroquoian Prehistory" in Trigger, B.G.; Handbook of NorthAmerican Indians. Washington, D.C.: Smithsonian Institution

Valaskakis, Gail Guthrie

2005 Indian Country - Essays on Contemporary Native Culture. Waterloo:

Wilfrid Laurier University Press

Waldram, James B.

1997 The Way of the Pipe - Aboriginal Spirituality and Symbolic Healing in Canadian Prisons. Orchard Park: broadview press

Walker, Renee C.

2001 "A Story of the Cultural Significance of the Ojibway Jingle Dress". MAThesis: University of Idaho, USA

Wheeler, Dennis; Shandel, Tom; U'mista Cultural Society of Alert Bay

1975

"Potlatch ... a strict law bids us dance". Film by Dennis Wheeler and Tom

Shandel (http://www.movingimages.ca; May 20, 2007).

White, Julia C.

1996 The Pow Wow Trail - The Native American Pow Wow. Summertown:

Book Publishing Company 
Willey, Gordon R.; Sabloff, Jeremy A.

1993 A History of American Archaeology. New York: W.H. Freeman and Company

Willey, Gordon R.

1966 An Introduction to American Archaeology - Volume One - North and Middle America. Englewood Cliffs: Prentice Hall Inc.

Wilson, Bryan R.

1973 Magic and the Millennium - A Sociological Study of Religious Movements of Protest among Tribal and Third-World Peoples. London: Heinemann

Windchief, Roberta

2002 "The Jingle Dance and the Assiniboine Sioux People of Montana" in Whispering Wind, Vol. 32, No. 6, pp. 16-20

Wright, J. V.

1972

Ontario Prehistory - An Eleven-thousand-year Archaeological Outline. Ottawa: National Museum of Man

Wright, Ronald

1993

Stolen Continents. Toronto: Penguin books Canada Ltd.

\section{CONSULTANTS}

Personal Interviews with two Ojibway Jingle Dress Dancers, August and October 2006 Personal Interview with Aboriginal (Potawatomi), October 2006 